\title{
Electrochemical energy storage in formate ions
}

Martijn Blom

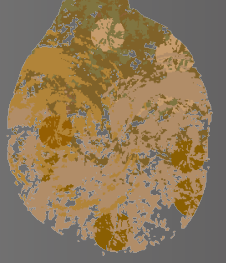





\section{ELECTROCHEMICAL ENERGY STORAGE IN FORMATE IONS}

Martijn Jan Willem Blom 
Dit proefschrift is goedgekeurd door:

Promotoren

prof. dr. S.R.A. Kersten

prof. dr. G. Mul

Cover design: A.K. van Duijne

Printed by: Gildeprint

Lay-out: M.J.W. Blom

ISBN: 978-90-365-5262-2

DOI: $10.3990 / 1.9789036552622$

(c) 2021 Martijn Jan Willem Blom, The Netherlands. All rights reserved. No parts of this thesis may be reproduced, stored in a retrieval system or transmitted in any form or by any means without permission of the author. Alle rechten voorbehouden. Niets uit deze uitgave mag worden vermenigvuldigd, in enige vorm of op enige wijze, zonder voorafgaande schriftelijke toestemming van de auteur. 


\title{
ELECTROCHEMICAL ENERGY STORAGE IN FORMATE IONS
}

\section{PROEFSCHRIFT}

\author{
ter verkrijging van \\ de graad van doctor aan de Universiteit Twente, \\ op gezag van de rector magnificus, \\ prof. dr. ir. A. Veldkamp, \\ volgens besluit van het College voor Promoties \\ in het openbaar te verdedigen \\ op vrijdag 22 oktober 2021 om 12.45 uur
}

door

Martijn Jan Willem Blom

geboren op 17 oktober 1992

in Sliedrecht 


\section{PROMOTIECOMMISSIE:}

Voorzitter / secretaris: $\quad$ prof.dr. J.L. Herek

Promotoren:

prof.dr. S.R.A. Kersten

prof.dr. G. Mul

Leden:

prof.dr.ir. L. Lefferts

prof.dr.ir. A. Nijmeijer

dr. J.A. Wood

prof. dr. W. Schuhmann

prof. dr. G. Rothenberg 


\section{Summary}

Renewable energy sources are increasingly important in meeting society's energy demand. In particular, penetration of wind and photovoltaic power is growing rapidly. This development is essential for the wellbeing of future generations, but is accompanied by many challenges. One of the most important technical challenges is security of supply of renewable energy. After all, there are windless, dark periods. This thesis focusses on a potential novel energy storage system to bridge those periods with stored energy from light, windy periods. The storage occurs through conversion of dissolved potassium bicarbonate into potassium formate, creating a safe and scalable system. Safe, as only non-flammable, non-toxic chemicals are used and scalable due to the liquid storage medium that can be pumped into tanks. Before the system can be realised, many questions need to be answered. Some of which, in this thesis.

First, in Chapter 2, the question is answered under which circumstances electrochemical conversion of bicarbonate to formate can occur. That is researched with a theoretical analysis of an electrolyzer, taking into account reactions at the electrode, transport through a membrane, exchange with a gas phase and the carbon dioxide-bicarbonate-carbonate equilibrium. From this mass balance analysis, it follows that the overall net conversion of the electrolyzer remains unchanged, when the electrochemically active species at the cathode is changed from bicarbonate to carbon dioxide. Consequently, electrodes designed for the reduction of carbon dioxide, which have been thoroughly studied in literature, can be utilized in the bicarbonate-formate storage system. Furthermore, due to the carbon dioxidebicarbonate-carbonate equilibrium, the desired conversion of bicarbonate to formate can only occur when protons are transported through the membrane into the catholyte.

Given the possibility to utilize electrodes designed for the reduction of carbon dioxide, Chapter 3 considers lead $(\mathrm{Pb})$ electrodes. Those are initially highly active and selective for formate production, but show reduced current density and a relative increase in undesired hydrogen production, within minutes. Brief anodic polarization of the electrode, restores the initial activity and selectivity. From in-situ Raman spectroscopy and thermodynamic analysis, it follows that lead carbonate is likely the electrochemically active phase. The lead carbonate degrades relatively slowly during production of formate, but can be regenerated relatively fast by anodic polarization. Therefore, pulsed electrochemistry can be a viable method to ensure a high average activity and selectivity of lead cathodes. However, for application in an energy storage system the overpotential is too high, which would result in excessive energy losses and low energy efficiency.

Therefore, in chapter 4, electrodes with a palladium catalyst are studied. Palladium has a low overpotential, but also produces relatively large amounts of undesired hydrogen. Fortunately, an increase in the partial pressure of hydrogen and therefore an increase in the concentration of hydrogen dissolved in the electrolyte, results in reduced net hydrogen production. A partial pressure of hydrogen of only 4 bars can be sufficient to prevent further hydrogen production and results in nearly exclusive formate production. At even higher partial pressures of hydrogen, there is net consumption of hydrogen from the gas phase. A 
reactor, in which the formed hydrogen accumulates through an increase in partial pressure and/or concentration, will therefore reach an operating point at which the net hydrogen production is zero. Consequently, the lack of intrinsic selectivity of palladium with regard to formate production does not have to be a showstopper for its application in the bicarbonateformate storage system.

Although an increase in the partial pressure of hydrogen has a clear effect on the net hydrogen production, it is not directly explicable with the reaction schemes presented in literature. Moreover, other have applied a small increase in the partial pressure of hydrogen and reported no effect on the net hydrogen production, but rather an increase in formate production. In chapter 5, an engineering method is applied to determine a suitable reaction mechanism. Several plausible mechanisms, substantiated by (literature) observations, are modelled. Then, modelled trends regarding reaction rates as function of experimental parameters are compared to experimentally observed trends. Mechanisms that are not able to describe all trends are dismissed. A mechanism based on both an $\alpha$ - and $\beta$-palladium hydride phase can describe the experimental results and correctly predicts the outcome of isotopically labelled experiments. From the mechanism and model, it follows that the ratio of $\alpha$ - and $\beta$ palladium hydride is a crucial factor in the intrinsic selectivity. The ratio itself is strongly influenced by the size, shape and support of the Pd nanoparticles. Furthermore, the proton reduction rate, which is highly dependent on the catalyst-ink layer properties, is a determining factor in the effect of the partial pressure of hydrogen on the formate and/or hydrogen production rate. Therefore, both aspects are highly relevant for further research. 


\section{Samenvatting}

Hernieuwbare energiebronnen vervullen een steeds belangrijker deel in de energiebehoefte van onze maatschappij. Met name de penetratie van elektrische energie uit zon en wind vordert met rasse schreden. Die ontwikkeling is essentieel voor het welzijn van toekomstige generaties, maar brengt ook uitdagingen met zich mee. Een van de belangrijkste technische uitdagingen is leveringszekerheid van duurzame energie. Er bestaan immers luwe, donkere periodes. Dit proefschrift focust op een potentieel nieuw energieopslagsysteem om deze periodes te overbruggen met opgeslagen energie uit lichte, windrijke periodes. Die opslag geschiedt middels omzetting van opgelost kaliumbicarbonaat naar kaliumformiaat, waarmee een veilig, schaalbaar opslagsysteem ontwikkeld kan worden. Veilig wegens het gebruik van onbrandbare, niet-giftige chemicaliën en schaalbaar door het gebruik een vloeibaar opslagmedium dat naar een tank verpompt kan worden. Voor het bicarbonaat-formiaat opslagsysteem kan worden gerealiseerd, moeten nog vele vragen beantwoord worden. Een deel daarvan in dit proefschrift.

Allereerst wordt in hoofdstuk 2 de vraag beantwoord onder welke omstandigheden elektrochemische conversie van opgelost bicarbonaat naar formiaat kan plaatsvinden. Dat geschiedt middels een theoretische beschouwing van een elektrolysetoestel, met inachtneming van reacties aan de elektrodes, transport door een membraan, uitwisseling met een gasfase en het koolstofdioxide-bicarbonaat-carbonaat evenwicht. Uit deze massabalans analyse blijkt dat het, voor de netto omzetting van het elektrolysetoestel, irrelevant is of koolstofdioxide dan wel bicarbonaat reageert aan de kathode. Derhalve kunnen kathodes gericht op koolstofdioxide reductie, waar al veelvuldig onderzoek naar gedaan is, toegepast worden. Verder blijkt, wegens het koolstofdioxide-bicarbonaat-carbonaat evenwicht, dat de gewenste omzetting van bicarbonaat naar formiaat alleen plaats kan vinden als er protonen door het membraan naar het katholyt getransporteerd worden.

Gegeven de mogelijkheid kathodes voor de reductie van koolstofdioxide te gebruiken, wordt in hoofdstuk 3 gekeken naar lood elektrodes. Deze zijn initieel zeer actief en selectief voor de productie van formiaat, maar blijken al na enkele minuten verminderde stroomdichtheid te vertonen, waarvan een groeiend aandeel voor de productie van ongewenst waterstof wordt aangewend. Kortstondige anodische polarisatie van het lood hersteld de initiële activiteit en selectiviteit. Middels in-situ Raman spectroscopie en thermodynamische analyse blijkt loodcarbonaat de katalytisch actieve fase voor formiaat productie, welke relatief langzaam degradeert tijdens formiaat productie, maar snel anodisch geregenereerd kan worden. Gepulseerde elektrochemie kan dus een effectieve methode zijn om een hoge gemiddelde activiteit en selectiviteit van lood elektrodes te waarborgen. Voor toepassing in een energieopslagsysteem, blijkt echter het overpotentiaal te hoog, waardoor de energieefficiëntie te laag zou zijn.

Derhalve worden in Hoofdstuk 4 elektrodes bestudeerd met palladium als katalysator, wat een laag overpotentiaal voor formiaat vorming heeft, maar ook grote hoeveelheden ongewenst waterstof produceert. Gelukkigerwijs leidt, verhoging van de partiële druk van waterstof en dus verhoging van de concentratie opgelost waterstof in het katholyt, tot een 
verlaagde waterstof productie. Al bij een partiële waterstof druk van 4 bar kan verdere waterstof vorming voorkomen worden en wordt nagenoeg alle stroom gebruikt voor formiaat productie. Bij een hogere partiële waterstof druk wordt zelfs netto waterstof uit de gasfase geconsumeerd. Een reactor waarbij het gevormde waterstof volledig kan ophopen in de reactor middels een druk en/of concentratieverhoging zal dus een punt bereiken waarop de netto waterstofvorming nul is. Dientengevolge hoeft het gebrek aan intrinsieke selectiviteit van palladium met betrekking tot formiaat vorming geen belemmering te zijn voor toepassing in het bicarbonaat-formiaat opslagsysteem.

Hoewel het verhogen van de partiële waterstofdruk en duidelijk effect heeft op de netto waterstofvorming, is dit niet direct te verklaren met in de literatuur geopperde reactiemechanismen. Bijkomend zijn er andere onderzoeksgroepen die bij een zeer kleine verhoging van de partiële waterstofdruk geen verandering in de waterstof productie observeerden, maar juist een verhoging van de formiaat productie. In Hoofdstuk 5 wordt een ingenieursmethode gebruikt om een passend reactiemechanisme te vinden. Verschillende plausibele mechanismen, onderbouwd door (literatuur) observaties, worden gemodelleerd. Gemodelleerde trends in reactiesnelheden als functie van experimentele parameters, worden vergeleken met experimenteel geobserveerde trends. Mechanismen die onder geen beding de experimentele trends konden beschrijven kunnen zo worden uitgesloten. Een mechanisme op basis van zowel een $\alpha$ - als $\beta$-palladiumhydride fase, blijkt de experimentele resultaten goed te beschrijven en ook de uitkomst van isotoop-gemarkeerde experimenten te voorspellen. Uit het mechanisme en model blijkt dat de verhouding tussen $\alpha$ - en $\beta$-palladiumhydride een bepalende rol in de intrinsieke selectiviteit heeft, welke sterk beïnvloed wordt door de grootte, vorm en drager van de palladium nadeeltjes. Daarnaast is de proton reductie snelheid, welke sterk onderhevig is aan de eigenschappen van de katalysator-inkt laag, bepalend is voor het effect van de partiële waterstofdruk op de snelheid van formiaat dan wel waterstof vorming. Beide aspecten zijn dus potentieel zeer relevant voor vervolgonderzoek. 



\section{Table of Contents}

$\begin{array}{lll} & \text { Summary } & \text { i } \\ & \text { Samenvatting } & \text { iii } \\ 1 & \text { Introduction } & 1 \\ 2 & \text { Mass balance evaluation for } \mathrm{CO}_{2} / \mathrm{HCO}_{3} \text { electrolyzer } & 15 \\ 3 & \text { Pulsed reduction of } \mathrm{CO}_{2} \text { on } \mathrm{Pb}_{\text {electrodes }} & 41 \\ 4 & \text { The effect of partial pressures of hydrogen and } \mathrm{CO}_{2} \text { on rate and } & 63 \\ & \text { selectivity at } \mathrm{Pd} / \mathrm{C} & \\ 5 & \text { Mechanism for } \mathrm{CO}_{2} \text { reduction on } \mathrm{Pd} / \mathrm{C} & 83 \\ 6 & \text { Conclusion, Outlook and Perspective } & 107 \\ 7 & \text { Acknowledgement } & 117 \\ & \text { List of journal publications } & 123 \\ & \text { About the author } & 125\end{array}$






\section{Chapter 1}

\section{Introduction}

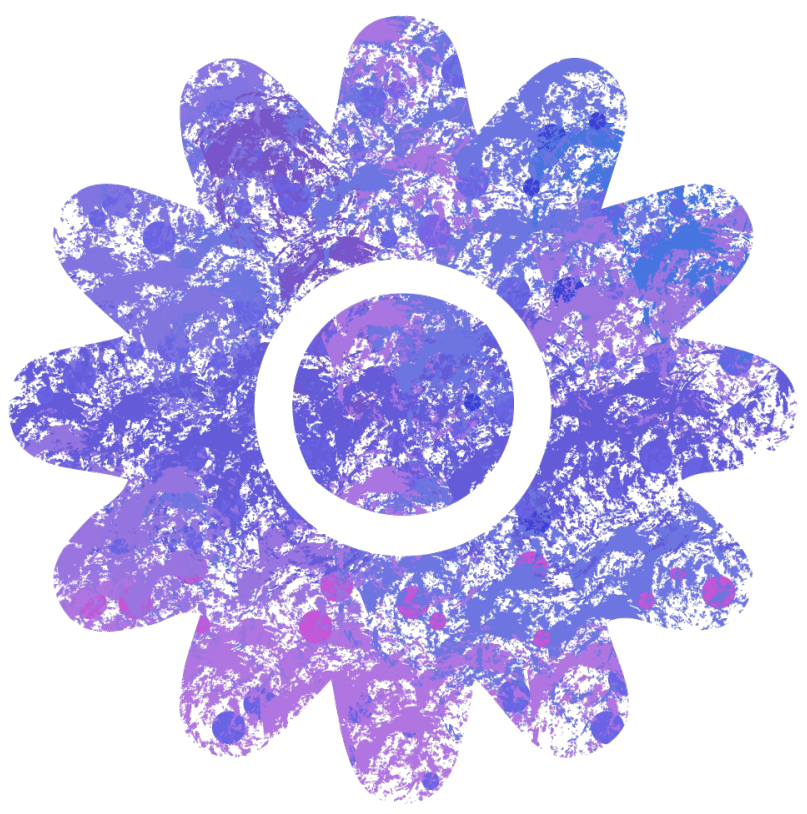

'The difficulty lies, not in the new ideas, but in escaping from the old ones'

- John Maynard Keynes - 
Every morning billions of people start their day. They might have a warm shower, cook breakfast or make a nice cup of hot coffee. Many of the smaller and larger pleasures in life require some form of energy. E.g., heat to warm your house and bake your eggs or electric power for air-conditioning and the coffeemaker. Throughout the majority of human history, people had to supply their energy need by their own manual labour and body heat. That changed 350000 years ago, when human-made wood fires started to find use in heating and cooking. Then, about 10000 year ago, draught animals were first utilized for their labour. Later energy was harnessed from wind to sail ships (3500 b. C) and power windmills (500 b. C). ${ }^{1}$

It was only in the $18^{\text {th }}$ century that non-renewables became a major energy source, displacing firewood for heat production due to increasing wood prices and decreasing availability. ${ }^{1}$ During the industrial revolution, the invention of the steam engine made large-scale conversion of thermal energy to work feasible and increased coal consumption to then unprecedented levels in Europe and the USA. ${ }^{2,3}$ In 1885, Karl Benz developed the first practical automobile with an internal combustion engine that ran on gasoline. An automotive industry developed soon and in 1908 Ford started production of the iconic model T, the first car that was widely available to the middle class. Gasoline demand rose accordingly, which initiated several oil booms worldwide. ${ }^{4}$ By 1965 oil had outgrown coal as the world prime energy source. ${ }^{2}$ Although the first natural gas well became operational in the USA in 1821, widespread use of naturally occurring natural gas was long time not feasible due to difficulties with transporting the flammable gas. Around 1900, advances in pipeline technologies contributed to the commissioning of the first major gas transmission pipeline, which was the start sign for development of vast pipeline network. ${ }^{5}$ The share of natural gas in the world energy mix has been steadily increasing ever since and some scenarios predict it will be the primary energy source worldwide in $2050{ }^{2,6}$

In current times, people are realizing more and more that we should move away from fossil resources. Whether that happens before we run out of fossil resources remains to be seen, but the fact of the matter is that, at some point, renewables will become the main energy source once again. Oil, coal and gas producing nations have had significant financial benefits from the energy industry. One can imagine that a similar wealth can be gained from renewable energy production technologies and sales. In the electric power sector, global investments in renewables already represent a larger value than those in fossil fuelled power since $2007 .{ }^{7}$

With the historic 2015 Paris Agreement, many countries (representing 87\% of the world greenhouse gas emissions) have committed themselves to attempt to keep the global temperature rise below $2^{\circ} \mathrm{C}$ compared to pre-industrial levels. ${ }^{8}$ While some countries have sadly chosen not to honour the agreement, others have translated the Paris agreement into well defined goals. For example, the European Union formulated the clear-cut goal of being climate neutral in 2050. ${ }^{9}$ That is not just a far dot on the horizon. In 2018, eighteen percent of the gross final energy consumption in Europe was renewable. ${ }^{10}$ Even a country as Germany, typically considered an industrial powerhouse and motor of the European economy, acquired more than sixteen percent of its energy need sustainably in $2018 .{ }^{10}$ Over 
$46 \%$ of their electric power generation for the public grid was renewable in $2019 .{ }^{11}$ The energy transition towards renewables is not just going to happen. It is already in full swing!

\subsection{The role of energy storage in the energy transition}

Up until now, the most crucial developments in renewable energy technology were accomplished in the power (electricity) sector. ${ }^{12}$ In general, the share of renewables is much larger in the power sector specifically, compared to the share of renewables in the total energy production. During the coming decades, the European power sector is expected to increase its share in the total energy demand from $22 \%$ in 2015 to $29-38 \%$ in $2050 .{ }^{13}$ In the most recent EU reference scenario, the integration of renewables in the European power sector grows from $21 \%$ in 2010 to $56 \%$ in 2050 . The majority of the expected growth spurt of renewables is accounted for by increases in solar power $(<1 \%$ in 2010 to $11 \%$ in 2050) and wind power (5\% in 2010 to $25 \%$ in 2050). ${ }^{14}$ Solar and wind power will be the workhorses for the energy transition in Europe.

As with any radical change, transitioning to renewables requires overcoming a multitude of hurdles. For integration of solar and wind power in the electricity grid, the three major challenges are all related to inherent properties of solar and wind power. First, the power output is as uncertain as the weather, which means that unplanned generation shortages or excesses are unavoidable and should be managed. Second, power output is location-specific, thus transmission is required for distribution from the places of generation to the place of consumption. Third, wind and solar show temporal variability (intermittence), whereas demand is relatively constant, which requires long-term supply/demand management. To put it bluntly, we are uncertain where, when and how much renewable power is available and the power that is available will probably not match our demand. ${ }^{15,16}$ Fortunately, electricity storage technologies can help mitigate these three issues.

Electricity storage can be a cost effective method, in addition to grid integration and demand side management, for integrating renewable power into the electricity grid. First, electricity storage can make up for the difference between forecasted renewable electricity production and actual electricity production, evening out short term imbalances. Second, storage can also aid in electricity transmission. For example storing part of the available solar power near the production site during the day when production is high and transmitting it at night when production is low, spreads the transmission of electricity over a longer period, reducing the required transmission capacity. Lastly, long-term storage of electricity can mitigate the intermittent nature of renewables and address supply/demand mismatches over longer periods. ${ }^{16,18}$

Electrical energy storage technologies are roughly divided in three categories (Figure 1.1). First, bulk scale energy storage with power outputs of more than $1 \mathrm{MW}$ and enough capacity for at least 1 hour of discharge. Second, distributed storage systems with similarly long discharge time, but less power output. Lastly, there is short-term storage, which provides power over seconds to minutes. Short-term electricity storage technologies are already widely available and find their use in maintaining balance in the current electricity grid. 
Long-term storage technologies, both bulk scale and distributed, are specific to a grid with a high percentage of intermittent renewable power. ${ }^{19}$

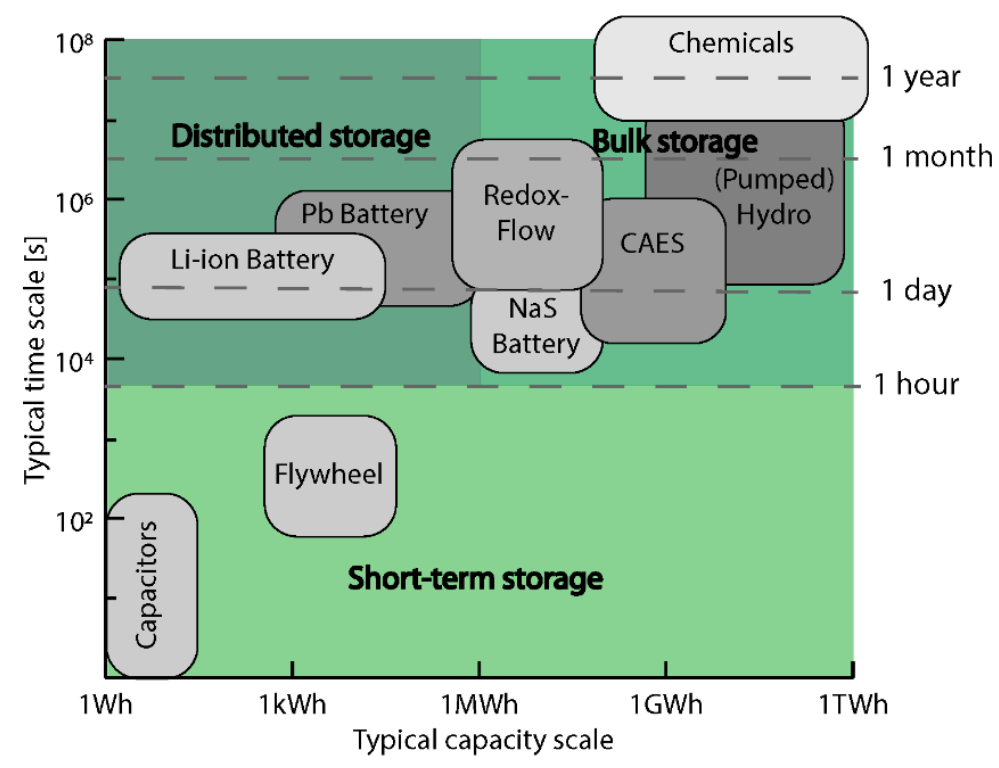

Figure 1.1: Typical capacities and time scales for selected storage technologies ${ }^{17}$

A multitude of long-term storage technologies for renewable energy is in various stages of development. Pumped hydro is the only mature technology and currently represents over $95 \%$ of the installed long-term storage capacity. ${ }^{20,21}$ It is cost effective and efficient $(75 \%$ $85 \%$ roundtrip), but limited to specific geographic locations and has a large environmental footprint due to vast water basins that have to be created. Therefore, only a limited increase in its capacity is predicted and complementary alternative storage technologies are expected to be implemented. ${ }^{16,22}$

Promising alternative large scale, long-term electricity storage technologies include power to hydrogen (to power), power to $\mathrm{X}$ (to power) and redox flow batteries. Power to hydrogen is the most mature technology of the alternatives. Renewable electricity powers electrolysers that convert water into hydrogen and oxygen. The hydrogen can be stored as pressurized or liquefied gas and later reconverted to power in a fuel cell. Alternatively, hydrogen can be used in various industries as a chemical or as a combustion fuel. The energy efficiency of commercialised power to hydrogen systems is about $70-75 \%{ }^{23}$ and the round trip energy efficiency (power to $\mathrm{H}_{2}$ to power )approximately 20-50\%. ${ }^{24,25} \mathrm{~A}$ drawback of power to hydrogen is the high logistics cost for transport and storage in areas that are not connected to a hydrogen gas grid. ${ }^{26}$ Power to $\mathrm{X}$ tries to solve that by substituting hydrogen for another chemical. Either vie subsequent conversion of hydrogen or direct electrochemical production. Potential chemicals include gasses as methane and ammonia and liquids as methanol, dimethyl ether and synthetic fuels. ${ }^{21}$ Whilst mitigating the logistics problem, 
production of those chemicals is far less facile than hydrogen production, resulting in higher costs and lower efficiencies. ${ }^{27}$ Power to $\mathrm{X}$ therefore has more potential as a technology for the production of value added chemicals and for demand side management, rather than as energy storage for conversion back to power. For round cycle power to power storage, redox flow batteries are more promising with an efficiency of around $85 \% .{ }^{28}$ Redox flow batteries exist in many forms, the most common being vanadium based and to a lesser extent $\mathrm{Zn}-\mathrm{Br}_{2}$ and Br-polysulfide systems. ${ }^{28}$ The working principle is similar to a rechargeable battery in the sense a reversible chemical reaction can produce and consume electricity. Contrary to batteries, the chemicals are not contained in the cell, but are liquid and can be pumped around storage tanks. Therefore, the size of the storage tanks limits the maximum amount of chemicals, hence storage capacity of a redox flow battery. The amount of electrode area in the redox flow battery dictates the power they can produce. Consequently, power and capacity are not coupled and contrary to a regular battery, both redox flow battery characteristics can be scaled independently.

An important factor in the effectiveness of electricity storage is the size, number and location of storage units. ${ }^{19}$ As an example, consider three extreme cases. Fully distributed storage at the production site (every solar panel has its own adequate storage unit), fully distributed storage at the consumption site (every consumer has its own adequate storage unit) and fully centralised storage (only one storage unit). With distributed storage at the production site, the only transport of electricity is from supplier to consumer and peak power demand dictates the minimum grid capacity. With distributed storage at the consumption site, again the only transport of electricity is from supplier to consumer, but now peak power production determines the minimum grid capacity. In both distributed storage options, there is no economy of scale advantage for each small storage unit. In centralised storage, the grid is used ineffectively, as power has to be transferred to the storage unit and then later again to the consumer. However, there is an economy of scale advantage for the large storage unit. In a future electricity grid with a high fraction of intermittent renewable power, there will be a combination of large centralised storage units near the large production sites and distributed storage near smaller production sited and at industrial and urban consumers. ${ }^{16,21,22,29,30}$

Distributed storage must work on a relatively small scale of around $1 \mathrm{MW}$ (adequate for about 3000 Dutch households). Therefore, pumped hydro and most power to X systems are inadequate. Pumped hydro storage typically works typically at a scale of 10-3000 $\mathrm{MW}^{31}$ and handling large amounts of water is too cumbersome in non-rural areas. Power to X typically involves a chemical hydrogenation reactor, which is difficult to scale down to less than 10$80 \mathrm{MW} .{ }^{32}$ Note that an average industrial size methanol plant corresponds to $800 \mathrm{MW} .{ }^{33}$ Current options for long-term electrochemical electricity storage are thus limited to power to hydrogen and redox flow batteries.

Close to or within the urban environment, safety and fear of risks are important issue for the acceptance of a storage technology by local inhabitants. ${ }^{34}$ Safety measures that are implemented in large-scale chemical plants can be too expensive to implement on a small scale. For example a single flammable gas sensor may cost $€ 2000$, negligible on a factory 
size, but significant for a small-scale system. Both power to hydrogen and most redox flow batteries are not intrinsically safe. Power to hydrogen requires large quantities of compressed flammable/explosive hydrogen gas and redox flow batteries require tanks of oftentimes toxic chemicals. ${ }^{35}$ This thesis focusses in the development of an alternative scalable storage system, based on an intrinsically safe storage medium: The bicarbonate-formate system.

\subsection{The bicarbonate formate system}

Interconversion of bicarbonate to formate (Reaction 1.1) is promising for the purpose of energy storage. When dissolved in water as potassium salt, the solubility of $\mathrm{KHCO}_{3}$ limits the bicarbonate/formate concentration to $2.8 \mathrm{kmole} / \mathrm{m}^{3}$, which results in an estimated maximum theoretical energy density of $183 \mathrm{kWh} / \mathrm{m}^{3}$. The energy density is in between that of typical redox flow batteries and regular battery technologies, as shown in Table 1.1. Therefore, the storage system does not require excessive space. More importantly, the bicarbonate-formate system has a large safety advantage over other energy storage systems. The bulk chemicals used in the bicarbonate-formate system $\left(\mathrm{KHCO}_{3}, \mathrm{KHCOO}\right.$ and $\left.\mathrm{H}_{2} \mathrm{O}\right)$ are all non-toxic, non-explosive and non-flammable. ${ }^{36}$ Therefore, far less risk is associated with implementing the bicarbonate-formate system near or even in urban areas.

$$
\mathrm{HCO}_{3}^{-} \rightleftarrows \mathrm{HCOO}^{-}+\frac{1}{2} \mathrm{O}_{2} \quad \Delta_{\mathrm{r}} G^{\circ}=236 \mathrm{~kJ} / \mathrm{mole} \quad \text { (Reaction 1.1) }
$$

Table 1.1: Theoretical maximum energy densities and reported state of the art values for several energy storage technologies

\begin{tabular}{llcll}
\hline Technology & $\begin{array}{l}\text { Theoretical } \\
\text { energy density }\end{array}$ & $\begin{array}{c}\text { maximum } \\
\left(\mathrm{MJ} / \mathrm{m}^{3}\right)^{*}\end{array}$ & $\begin{array}{l}\text { State of the art experimental } \\
\text { energy density }\left(\mathrm{MJ} / \mathrm{m}^{3}\right)\end{array}$ \\
\hline $\mathrm{H}_{2}$ (gas, 1 atm.) & 10 & 37 & - & 38 \\
$\mathrm{H}_{2}$ (gas, 700 atm.) & 5000 & 39 & 2960 & 28 \\
Vanadium redox flow & 160 & 40 & 120 & 41 \\
Br-Polysulfide redox flow & 420 & 42,43 & 2500 & 44 \\
Li-ion battery (single cell) & 6800 & 43 & 1500 & 45 \\
NiMH battery & 3200 & 46 & 320 & 47 \\
Lead-acid battery & 1400 & & - & \\
Bicarbonate-Formate system & 660 & & & \\
\hline
\end{tabular}

The bicarbonate formate system can be implemented in two configurations. The first option is fully electrochemical, with electricity as both input and delayed output, as illustrated in Figure 1.1. In the charge step, surplus electricity is used in an electrolyser to convert dissolved bicarbonate from a storage tank into formate (Reaction 1.1). The resulting potassium formate solution is then stored. When demand for electricity is high, formate is converted back to bicarbonate in a discharge step, via the reverse of Reaction 1.1, which generates electricity.

\footnotetext{
* Theoretical capacity estimated from standard Gibbs free energy of formation and (maximum) concentration/density at $298 \mathrm{~K}$, disregarding activity coefficients and pressure effects
} 
The resulting potassium bicarbonate solution is stored. Overall, the electrochemical configuration (Figure 1.2) stores electricity over time.

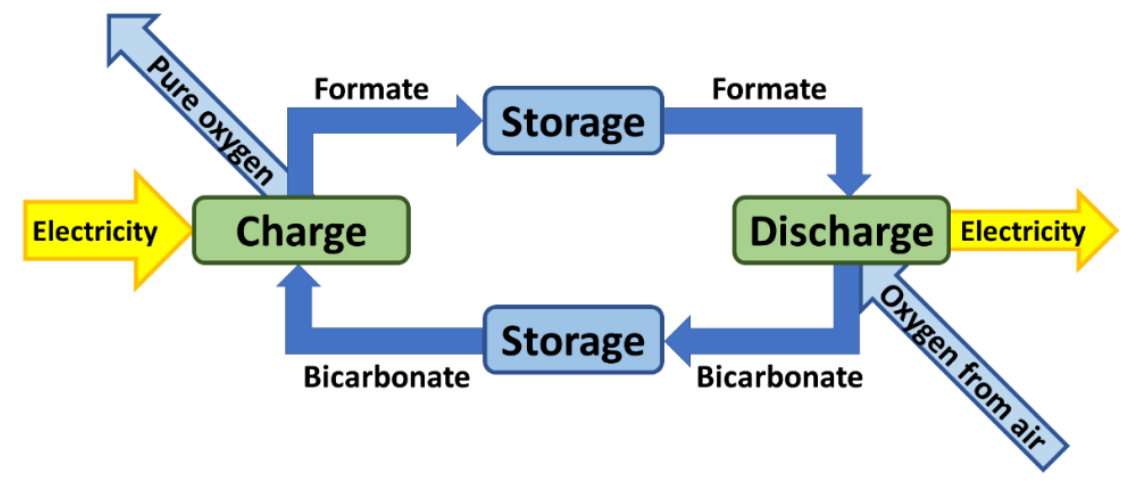

\section{Figure 1.2: Schematic representation of bicarbonate-formate system for electricity storage}

The second configuration is an electrochemical charge step with a delayed chemical conversion to hydrogen instead of the discharge step. In the conversion step, formate is converted to hydrogen via Reaction 1.2. Hydrogen is subsequently available as chemical feedstock or fuel. Overall, the second configuration has electricity as input and hydrogen as delayed output, which corresponds to combined electrochemical hydrogen production and storage in a safe medium.

$$
\mathrm{HCOO}^{-}+\mathrm{H}_{2} \mathrm{O} \rightleftarrows \mathrm{HCO}_{3}^{-}+\mathrm{H}_{2} \quad \Delta_{\mathrm{r}} G^{\circ}=-1 \mathrm{~kJ} / \mathrm{mole} \quad \text { (Reaction 1.2) }
$$

Theoretically, the bicarbonate-formate storage system offers safe energy storage at acceptable energy density. Parts of the system were already researched as both hydrogen storage medium and electricity storage medium. The majority of existing research focusses on hydrogen storage by hydrogenation of bicarbonate to formate (reverse of Reaction 1.2) and dehydrogenation of formate (Reaction 1.2). ${ }^{36,48,49}$ Promising heterogeneous catalysts are typical (de-)hydrogenation catalysts based on e.g. palladium, nickel or ruthenium. ${ }^{48,50}$ In the grand scheme of the energy transition, hydrogen is likely generated via water electrolysis. Therefore, the electricity-to-hydrogen configuration (Figure 1.3) can be seen as an intensified version of electrochemical hydrogen production and storage in formate. Ultimately, the goal would be to perform both steps (charge and discharge or charge and conversion) with the same reactor. 


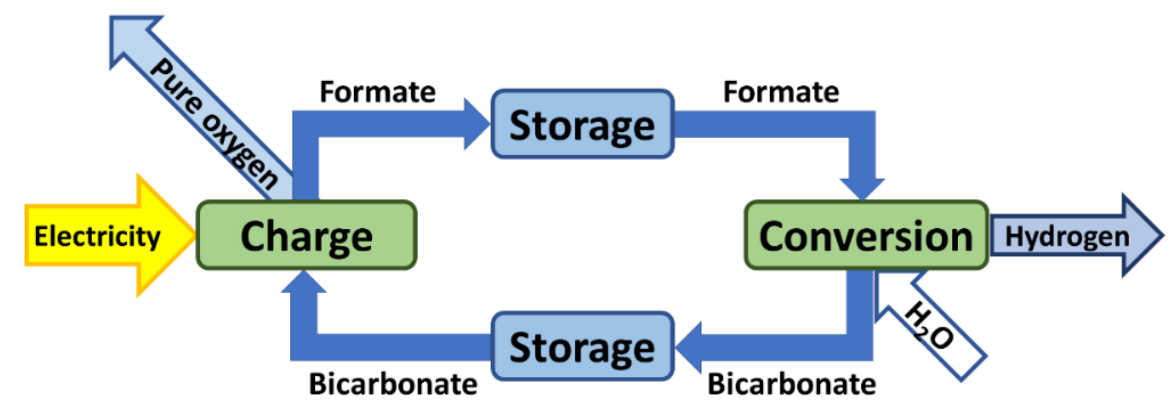

Figure 1.3: Schematic representation of bicarbonate-formate system for
hydrogen generation and storage

\subsection{Scope and outline}

Considering the two major steps of the storage system, charge and discharge/conversion, literature data on the discharge/conversion steps is mostly promising and unambiguous. Literature shows chemical conversion of formate to hydrogen and bicarbonate (Reaction 1.2) at over $90 \%$ yield on various heterogeneous and homogeneous catalysts. ${ }^{48,51-53}$ Several benchtop-scale reactors are described in literature. ${ }^{51,52}$ Discharge of formate in direct formate fuel cells, has drawn significant attention in recent years and various efforts yielded fuel cells with up to $50-60 \%$ energy efficiency. ${ }^{54-56}$ It is suggested that conversion of formate to hydrogen and subsequent utilisation in a hydrogen fuel cell may be another viable option. ${ }^{51}$

Far less knowledge is available regarding electrochemical conversion of bicarbonate into formate. Many publications regarding electrochemical reduction of bicarbonate to formate were published several decades ago. ${ }^{57-59}$ More recent literature, with similar reaction conditions including bicarbonate in solution, regards dissolved $\mathrm{CO}_{2}$ as the reactive species on various catalysts. ${ }^{60-63}$ No consensus is yet reached on the (catalyst dependent) reactive species on formate producing electrocatalysts. The consequences of either species being the reactive species are for now unexplored. Moreover, selectivity for formate production is oftentimes not $100 \%$ as hydrogen is formed in a side reaction (Reaction 1.3). Much variation is reported in literature, even for the same catalytic material (e.g. for Pb electrodes, selectivity ranges from 10-90\%). ${ }^{64-68}$ Therefore, the majority of this thesis focusses on electrochemical production of formate, with specific focus on the overall mass balance, selectivity and energy efficiency.

$\mathrm{H}_{2} \mathrm{O} \rightleftarrows \mathrm{H}_{2}+\frac{1}{2} \mathrm{O}_{2} \quad \Delta_{\mathrm{r}} G^{\circ}=-237 \mathrm{~kJ} / \mathrm{mole} \quad$ (Reaction 1.3) 


\subsubsection{Overall mass balance}

During (electro)chemical conversion of bicarbonate into formate, a presence of $\mathrm{CO}_{2}$ has a positive effect on the reaction rate. ${ }^{60,69}$ The majority of electro-chemical research reports $\mathrm{CO}_{2}$ as reactive species at the electrode. ${ }^{60-63}$ However, $\mathrm{CO}_{2}$ reduction to formate is much slower without the presence of bicarbonate..$^{70-72}$ Recent literature suggests elaborate interplay between $\mathrm{HCO}_{3}{ }^{-}$and $\mathrm{CO}_{2}$ during electrochemical production of formate. ${ }^{61,73,74}$ Likely, the carbon dioxide - bicarbonate - carbonate equilibrium (Reaction 1.4) has an influence on the interplay. The carbonaceous equilibrium may also influence the overall mass balance over the electrochemical reactor, which is even further complicated by the anode reaction and transport through the charge selective membrane that is typically necessary in an electrochemical reactor. Chapter 2 explores the effect of the reactive species, the carbonaceous equilibrium and membrane/electrolyte choice on the mass balance and overall conversion of an electrochemical formate production reactor, with the aim of identifying viable reactor designs.

$\mathrm{CO}_{2} \underset{-\mathrm{H}_{2} \mathrm{O}}{\stackrel{+\mathrm{H}_{2} \mathrm{O}}{\rightleftarrows}} \mathrm{H}_{2} \mathrm{CO}_{3} \underset{+\mathrm{H}^{+}}{\stackrel{-\mathrm{H}^{+}}{\rightleftarrows}} \mathrm{HCO}_{3} \underset{+\mathrm{H}^{+}}{\stackrel{-\mathrm{H}^{+}}{\rightleftarrows}} \mathrm{CO}_{3}^{2-}$

(Reaction 1.4)

\subsubsection{Selectivity}

Formate is not the sole product for electrochemical reduction of $\mathrm{CO}_{2} / \mathrm{HCO}_{3}{ }^{-}$. Hydrogen evolution (Reaction 1.3) that results from water electrolysis limits the selectivity to formate. Pristine, lead based electrodes pose high selectivity towards formate, as high as $100 \%$, but selectivity between sources varies drastically and seems to decline over time. In chapter $\mathbf{3}$, we will explore the origin of this phenomenon and utilize it to increase the time-averaged activity of $\mathrm{Pb}$ electrodes for formate production.

\subsubsection{Energy efficiency}

The minimal potential required to make an electrochemical reaction possible is determined by thermodynamics. Oftentimes, an overpotential is required to make the reaction run at a significant rate. The majority of the excess energy input from this overpotential is converted to heat and a smaller fraction is consumed by the endothermic nature of some electrochemical reactions. In ambient pressure aqueous systems, the overpotential results in undesired low temperature heat. Palladium electrocatalysts typically exhibit especially low overpotentials. Unfortunately, the intrinsic selectivity towards formate is much less as compared to other catalysts. However, palladium is also known for formate production via hydrogenation of $\mathrm{CO}_{2} / \mathrm{HCO}_{3}{ }^{-}$, which consumes hydrogen. Chapter 4 combines formate production via electrochemical reduction and chemical hydrogenation with the aim to reduce net hydrogen production. 


\subsubsection{Reaction mechanism}

Where chapter 4 considers practical aspects of combined hydrogenation and electrolysis of $\mathrm{CO}_{2}$, the next chapter focusses on kinetics, as reaction mechanisms in literature cannot fully describe the behaviour observed on Pd catalysts. Electrokinetic studies oftentimes feature density functional theory (DFT) calculations supplemented with measurements of the Tafel slope. Another approach is operando spectroscopy, typically performed in a synchrotron setting. Both approaches are quite complicated, especially for initial evaluation of potential mechanisms. Chapter 5 describes and applies an engineering method, historically used for finding catalytic reaction mechanisms, to electrochemistry using formate production on $\mathrm{Pd}$ as a case study.

Finally, chapter 6 contains a summary of the main conclusions and reflects on the work in this thesis in light of the research questions, other technological developments and perspective for the future. 


\section{References}

1. Sorensen, B. A history of renewable energy technology. (1991).

2. $\quad$ Ritchie, H. \& Roser, M. Energy. Our World in Data (2020).

3. Solomon, B. \& Yough, P. Coal Trains: The History of Railroading and Coal in the Unites States. (Voyageur Press, 2009).

4. Owen, E. W. Trek of the oil finders: a history of exploration for petroleum.

5. $\quad$ Meisner, T. O. \& Leffler, W. L. Oil \& Gas pipelines. (2006).

6. World Energy Counsil, W. E. C. World Energy Scenarios: Composing energy futures to 2050. Rep. From Http//Www.Worldenergy.Org/1-288 (2013). doi:ISBN: 9780946121335

7. World Energy Investment 2019. World Energy Invest. 2019 (2019). doi:10.1787/4f4f25b4-en

8. United Nations. Paris Agreement. (2015).

9. European Commission. A Clean Planet for all - A European long-term strategic vision for a prosperous , modern, competitive and climate neutral economy. Com(2018) 773. (2018).

10. Eurostat. Renewable energy in the EU in 2018. Newsrelease 32-34 (2020).

11. Fraunhofer ISE. Public Net Electricity Generation in Germany 2019. Public Net Electricity Generation in Germany 2019: Share from Renewables Exceeds Fossil Fuels (2020).

12. Aklin, M. \& Urpelainen, J. Renewables: The politics of a global energy transition. (MIT Press, 2018).

13. European Commission. Energy roadmap 2050. (2012). doi:10.2833/10759

14. Capros, P. et al. EU Reference Scenario 2016-Energy, transport and GHG emissions Trends to 2050. (European Commission Directorate-General for Energy, 2016). doi:10.2833/9127

15. Ueckerdt, F., Brecha, R. \& Luderer, G. Analyzing major challenges of wind and solar variability in power systems. Renew. Energy 81, 1-10 (2015).

16. Sandén, B. Systems Perspectives on Renewable Power. (2014).

17. Bos, M. Storage of Renewable Electricity in Methanol. (2019).

18. Babrowski, S., Jochem, P. \& Fichtner, W. Electricity storage systems in the future German energy sector: An optimization of the German electricity generation system until 2040 considering grid restrictions. Comput. Oper. Res. 66, 228-240 (2016).

19. Crossland, A. F., Jones, D. \& Wade, N. S. Planning the location and rating of distributed energy storage in LV networks using a genetic algorithm with simulated annealing. Int. J. Electr. Power Energy Syst. 59, 103-110 (2014).

20. Barbour, E., Wilson, I. A. G., Radcliffe, J., Ding, Y. \& Li, Y. A review of pumped hydro energy storage development in significant international electricity markets. Renew. Sustain. Energy Rev. 61, 421-432 (2016).

21. Ease/Eera. European Energy Storage Technology Development Roadmap. 2017 (2017).

22. Report, F. Study on energy storage - Contribution to the security of the electricity supply in Europe. (2020).

23. Ivy, J. Summary of Electrolytic Hydrogen Production Milestone Completion Report. Small 27 (2004). doi:10.1126/science.1066771

24. Kousksou, T., Bruel, P., Jamil, A., El Rhafiki, T. \& Zeraouli, Y. Energy storage: Applications and challenges. Sol. Energy Mater. Sol. Cells 120, 59-80 (2014).

25. ATKearney. Electricity Storage Gaining Momentum. 1-100 (2018).

26. IRENA. Hydrogen: a Renewable Energy Perspective. International Renewable Energy Agency (2019).

27. Schiebahn, S. et al. Power to gas: Technological overview, systems analysis and economic assessment for a case study in Germany. Int. J. Hydrogen Energy 40, 4285-4294 (2015).

28. Alotto, P., Guarnieri, M. \& Moro, F. Redox flow batteries for the storage of renewable energy: A review. Renew. Sustain. Energy Rev. 29, 325-335 (2014).

29. European Association for Storage of Energy. Energy Storage for a Decarbonised Europe by 2050. (2019).

30. Noe, P. M., Südmeyer, I. J. \& Bardají, M. E. G. Study on Mission- Oriented R \& I Energy 
Storage. (2018).

31. EASE - European Association for Energy Storage. Energy Storage Technology Descriptions Pumped Hydro Storage. 1-2 (2011). doi:10.1007/10858992

32. Conference, I. M. Small scale Methanol Plants a chance for re-industrialisation. (2017).

33. Ott, J. et al. Methanol. in Ullmann's Encyclopedia of Industrial Chemistry (American Cancer Society, 2012). doi:10.1002/14356007.a16_465.pub3

34. Zaunbrecher, B. S., Bexten, T., Wirsum, M. \& Ziefle, M. What is Stored, Why, and How? Mental Models, Knowledge, and Public Acceptance of Hydrogen Storage. Energy Procedia 99, 108-119 (2016).

35. Weber, A. Z. et al. Redox flow batteries: A review. J. Appl. Electrochem. 41, 1137-1164 (2011).

36. Boddien, A. et al. CO2-"Neutral" Hydrogen Storage Based on Bicarbonates and Formates. Angew. Chemie - Int. Ed. 50, 6411-6414 (2011).

37. Carriveau, R. \& Ting, D. S.-K. Methane and Hydrogen for Energy Storage. (Institution of Engineering and Technology).

38. US DOE. Target Explanation Document: Onboard Hydrogen Storage for Light-Duty Fuel Cell Vehicles. U.S Drive 1-29 (2017).

39. Duan, W. et al. Towards an all-vanadium redox flow battery with higher theoretical volumetric capacities by utilizing the VO2+/V3+ couple. J. Energy Chem. 27, 1381-1385 (2018).

40. Gross, M. M. \& Manthiram, A. Long-Life Polysulfide-Polyhalide Batteries with a MediatorIon Solid Electrolyte. ACS Appl. Energy Mater. 2, 3445-3451 (2019).

41. Zhang, S. et al. Recent Progress in Polysulfide Redox-Flow Batteries. Batter. Supercaps 2, 627-637 (2019).

42. Zubi, G., Dufo-lópez, R., Carvalho, M. \& Pasaoglu, G. The lithium-ion battery: State of the art and future perspectives. 89, 292-308 (2018).

43. $\mathrm{Zu}, \mathrm{C} . \mathrm{X} . \& \mathrm{Li}, \mathrm{H}$. Thermodynamic analysis on energy densities of batteries. Energy Environ. Sci. 4, 2614-2624 (2011).

44. Panasonic. Specifications for NCR18650GA. 65-68 (2019).

45. Fetcenko, M. A. et al. Recent advances in NiMH battery technology. J. Power Sources 165, 544-551 (2007).

46. Matteson, S. \& Williams, E. Residual learning rates in lead-acid batteries: Effects on emerging technologies. Energy Policy 85, 71-79 (2015).

47. May, G. J., Davidson, A. \& Monahov, B. Lead batteries for utility energy storage: A review. J. Energy Storage 15, 145-157 (2018).

48. Gunasekar, G. H., Park, K., Jung, K.-D. \& Yoon, S. Recent developments in the catalytic hydrogenation of $\mathrm{CO}_{2}$ to formic acid/formate using heterogeneous catalysts. Inorg. Chem. Front. 3, 882-895 (2016).

49. Engel, D. C., Versteeg, G. F. \& van Swaaij, W. P. M. Chemical equilibrium of hydrogen and aqueous solutions of 1:1 bicarbonate and formate salts with a common cation. Fluid Phase Equilib. 135, 109-136 (1997).

50. Bulushev, D. A. \& Ross, J. R. H. Heterogeneous catalysts for hydrogenation of $\mathrm{CO} 2$ and bicarbonates to formic acid and formates. Catal. Rev. - Sci. Eng. 60, 566-593 (2018).

51. Caiti, M., Padovan, D. \& Hammond, C. Continuous Production of Hydrogen from Formic Acid Decomposition Over Heterogeneous Nanoparticle Catalysts: From Batch to Continuous Flow. ACS Catal. 9, 9188-9198 (2019).

52. Hwang, Y. J. et al. Development of an Autothermal Formate-Based Hydrogen Generator: From Optimization of Formate Dehydrogenation Conditions to Thermal Integration with Fuel Cells. ACS Sustain. Chem. Eng. (2020). doi:10.1021/acssuschemeng.0c02775

53. $\mathrm{Bi}, \mathrm{Q}$. Y. et al. An aqueous rechargeable formate-based hydrogen battery driven by heterogeneous Pd catalysis. Angew. Chemie - Int. Ed. 53, 13583-13587 (2014).

54. Tran, K., Nguyen, T. Q., Bartrom, A. M., Sadiki, A. \& Haan, J. L. A fuel-flexible alkaline direct liquid fuel cell. Fuel Cells 14, 834-841 (2014). 
55. Saric, S. et al. An integrated device to convert carbon dioxide to energy. Appl. Energy 183, 1346-1350 (2016).

56. Miller, H. et al. Improving the Energy Efficiency of Direct Formate Fuel Cells with a Pd/C$\mathrm{CeO} 2$ Anode Catalyst and Anion Exchange Ionomer in the Catalyst Layer. Energies 11, 369 (2018).

57. Stalder, C. J., Chao, S. \& Wrighton, M. S. Electrochemical Reduction of Aqueous Bicarbonate to Formate with High Current Efficiency Near the Thermodynamic Potential at Chemically Derivatized Electrodes. J. Am. Chem. Soc. 106, 3673-3675 (1984).

58. Spichiger-Ulmann, M. \& Augustynski, J. Electrochemical reduction of bicarbonate ions at a bright palladium cathode. J. Chem. Soc. Faraday Trans. 1 Phys. Chem. Condens. Phases 81, 713 (1985).

59. Stalder, C. J., Chao, S., Summers, D. P. \& Wrighton, M. S. Supported Palladium Catalysts for the Reduction of Sodium Bicarbonate to Sodium Formate in Aqueous Solution at Room Temperature and One Atmosphere of Hydrogen. J. Am. Chem. Soc. 105, 6318-6320 (1983).

60. Min, X. \& Kanan, M. W. Pd-Catalyzed Electrohydrogenation of Carbon Dioxide to Formate: High Mass activity at Low Overpotential and Identification of the Deactivation Pathway. $J$. Am. Chem. Soc. 137, 4701-4708 (2015).

61. Zhu, S., Jiang, B., Cai, W. Bin \& Shao, M. Direct Observation on Reaction Intermediates and the Role of Bicarbonate Anions in CO2 Electrochemical Reduction Reaction on Cu Surfaces. J. Am. Chem. Soc. 139, 15664-15667 (2017).

62. Goyal, A., Marcandalli, G., Mints, V. A. \& Koper, M. T. M. Competition between CO 2 Reduction and Hydrogen Evolution on a Gold Electrode under Well-De fi ned Mass Transport Conditions. 2, (2020).

63. Kortlever, R., Shen, J., Schouten, K. J. P., Calle-Vallejo, F. \& Koper, M. T. M. Catalysts and Reaction Pathways for the Electrochemical Reduction of Carbon Dioxide. J. Phys. Chem. Lett. 6, 4073-4082 (2015).

64. Hori, Y., Wakebe, H., Tsukamoto, T. \& Koga, O. Electrocatalytic process of CO selectivity in electrochemical reduction of $\mathrm{CO} 2$ at metal electrodes in aqueous media. Electrochim. Acta 39, 1833-1839 (1994).

65. Köleli, F. et al. Electrochemical reduction of $\mathrm{CO} 2$ at $\mathrm{Pb}$-and $\mathrm{Sn}$-electrodes in a fixed-bed reactor in aqueous K2CO3 and KHCO3 media. J. Appl. Electrochem. 33, 447-450 (2003).

66. Innocent, B. et al. Electro-reduction of carbon dioxide to formate on lead electrode in aqueous medium. J. Appl. Electrochem. 39, 227-232 (2009).

67. Lee, C. H. \& Kanan, M. W. Controlling H+ vs CO2 Reduction Selectivity on Pb Electrodes. ACS Catal. 5, 465-469 (2015).

68. Azuma, M., Hashimoto, K., Hiramoto, M., Watanabe, M. \& Sakata, T. Electrochemical Reduction of Carbon Dioxide on Various Metal Electrodes in Low-Temperature Aqueous Media. Journal of The Electrochemical Society 137, 1772-1778 (1990).

69. Engel, D. C., Versteeg, G. F. \& Van Swaaij, W. P. M. Reaction kinetics of hydrogen and aqueous sodium and potassium bicarbonate catalysed by palladium on activated carbon. Chemical Engineering Research and Design 73, 701-706 (1995).

70. Bevilacqua, M., Filippi, J., Miller, H. A. \& Vizza, F. Recent Technological Progress in CO2 Electroreduction to Fuels and Energy Carriers in Aqueous Environments. Energy Technol. 3, 197-210 (2015).

71. Zhang, W. et al. Progress and Perspective of Electrocatalytic CO2 Reduction for Renewable Carbonaceous Fuels and Chemicals. Adv. Sci. 5, 1-24 (2018).

72. Lu, X., Leung, D. Y. C., Wang, H., Leung, M. K. H. \& Xuan, J. Electrochemical Reduction of Carbon Dioxide to Formic Acid. ChemElectroChem 1, 836-849 (2014).

73. Wuttig, A., Yoon, Y., Ryu, J. \& Surendranath, Y. Bicarbonate Is Not a General Acid in AuCatalyzed CO2 Electroreduction. J. Am. Chem. Soc. 139, 17109-17113 (2017).

74. Dunwell, M. et al. The Central Role of Bicarbonate in the Electrochemical Reduction of Carbon Dioxide on Gold. J Am Chem Soc 139, 3774-3783 (2017). 



\section{Chapter 2}

\section{Mass balance evaluation for $\mathrm{CO}_{2} / \mathrm{HCO}_{3}^{-}$ electrolyser}

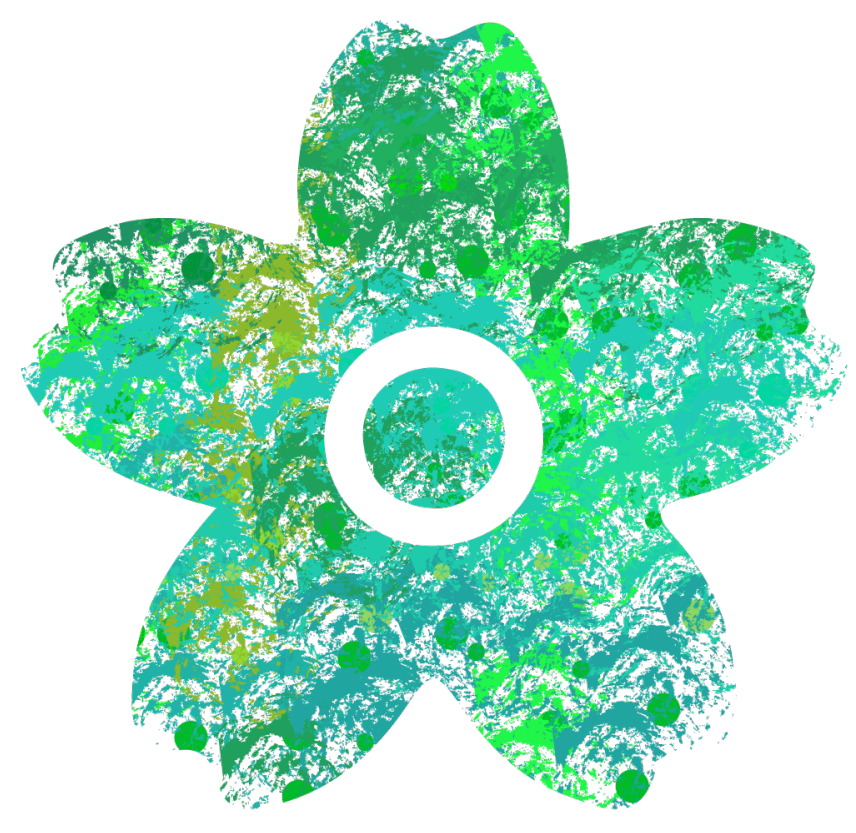

'Simplicity is an excat medium between too little and too much'

- Sir Joshua Reynolds - 


\begin{abstract}
The overall mass balance of an electrochemical reactor is a key instrument in assessing the viability of an electrochemical process, but is not immediately obvious from only the halfreactions. This chapter provides a simplified method to estimate the overall mass balance and electrolyte composition of electrochemical conversion systems and applies it to several $\mathrm{CO}_{2} / \mathrm{HCO}_{3}{ }^{-}$conversion systems for the production of $\mathrm{HCOOH}^{-} \mathrm{HCOO}^{-}$. In addition to the half-reactions, the method also considers transport through membranes, transport between phases and homogenous (acid-base) reactions. Due to the acidity of $\mathrm{HCOOH}$, in the presence of $\mathrm{HCO}_{3}^{-}, \mathrm{HCOO}^{-}$is formed, resulting in $\mathrm{HCOO}^{-}$production and negligible $\mathrm{HCOOH}$ yields. Moreover, due to the $\mathrm{CO}_{2}-\mathrm{HCO}_{3}{ }^{-}-\mathrm{CO}_{3}{ }^{2-}$ equilibrium, the overall balance is independent of $\mathrm{CO}_{2}$ or $\mathrm{HCO}_{3}{ }^{-}$being the reactive species. Therefore, under suitable conditions, $\mathrm{CO}_{2}$ reduction catalysts can be utilized for overall conversion of $\mathrm{HCO}_{3}{ }^{-}$to $\mathrm{HCOO}^{-}$. The requirements for $\mathrm{HCO}_{3}{ }^{-}$to $\mathrm{HCOO}^{-}$and $\mathrm{CO}_{2}$ to $\mathrm{HCOOH}$ conversion are discussed.
\end{abstract}

This chapter has been published as :

Blom, M. J. W., van Swaaij, W. P. M., Mul, G. \& Kersten, S. R. A. Overall mass balance evaluation of electrochemical reactors: The case of $\mathrm{CO}_{2}$ reduction. Electrochim. Acta 333, (2020). 


\section{Nomenclature}

\begin{tabular}{lll}
\hline Variable & Description & unit \\
\hline$c_{i}^{j}$ & Concentration of species i in electrolyte j & $\mathrm{mole} / \mathrm{L}$ \\
$c_{i, i n}^{j}$ & Concentration of species i in inlet flow to electrolyte $\mathrm{j}$ & $\mathrm{mole} / \mathrm{L}$ \\
$\mathrm{F}$ & Faraday constant & $\mathrm{C} / \mathrm{mole}$ \\
$f_{i}^{j}$ & Molar gas liquid exchange of species i to electrolyte $\mathrm{j}$ & $\mathrm{mole} / \mathrm{s}$ \\
$I$ & Current through reactor & $\mathrm{A}$ \\
$J_{i}$ & Molar transfer of species i across membrane & $\mathrm{mole} / \mathrm{s}$ \\
$n$ & Number of electrons in electrochemical reaction & - \\
$R_{\text {batch }}^{j}$ & Electrochemical productivity of batch reactor for electrolyte j (Faradaic & $\mathrm{C} / \mathrm{L}$ \\
$R_{f l o w}^{j}$ & charge in Coulomb, passed through one litre of electrolyte j) & \\
& Electrochemical productivity of steady state flow reactor for electrolyte & $\mathrm{C} / \mathrm{L}$ \\
$t$ & $\mathrm{j}$ (Faradaic charge in Coulomb, passed through one litre of electrolyte & \\
$\overline{t_{i}}$ & $\mathrm{j}$ ) & \\
$V^{j}$ & time & $\mathrm{s}$ \\
$z_{i}$ & Transport number of species i & - \\
$\phi_{V}^{j}$ & Colume of liquid electrolyte j & $\mathrm{L}$ \\
$v_{i}^{j}$ & Volumetric flow rate of electrolyte j & - \\
\hline Sub- and superscripts & $\mathrm{L} / \mathrm{s}$ \\
\hline $\mathrm{c}$ & Cathode/catholyte & - \\
$i$ & Species & - \\
$j$ & Electrolyte, e.g. catholyte & - \\
inter & Interface region between bipolar membrane layers & - \\
\hline & & - \\
\hline
\end{tabular}

\subsection{Introduction}

Many publications focused on the electrochemical production of formate and formic acid, state that $\mathrm{CO}_{2}$ is converted to either formic acid or formate. ${ }^{1-4}$ However, these studies are oftentimes conducted at low conversion and in the presence of $\mathrm{HCO}_{3}{ }^{-}$, another possible carbon source. ${ }^{5-8}$ Therefore, without attention to the overall mass balance, it is unclear whether the claimed conversion really occurred. A favourable mass balance is of vital importance to any conversion process, as it dictates what is produced and in which amounts. ${ }^{9}$ The mass balance of an electrochemical reactor is typically not directly obvious from the reaction equations. Unlike a conventional chemical reactor, where the overall conversion is usually the same as the reaction at the catalyst, the overall conversion of an electrochemical reactor includes the sum of reactions at the cathode and anode, and may be dependent on transport through a charge-selective membrane. Moreover, reactions at the cathode and anode, and charge transport are all coupled via the charge balance, which further convolutes the overall balance. Specific to $\mathrm{CO}_{2}$ conversion to formate, there is even uncertainty regarding the reactive species at the cathode, being either $\mathrm{CO}_{2}$ or formate. ${ }^{8,10-12}$ 
Therefore, this chapter introduces a simple method for evaluating the mass balance of an electrochemical reactor and applies that to $\mathrm{CO}_{2} / \mathrm{HCO}_{3}{ }^{-}$reduction systems. First, the method is applied to typical electrochemical reactor setups encountered in literature, with the aim to study how the membrane, anolyte, catholyte and reactive species, influence the overall mass balance. From there, the design space is explored further, to find a viable reactor design for the concept of this thesis, namely electrochemical conversion of bicarbonate to formate.

\subsection{The overall mass balance}

As a minimum requirement, an electrochemical reactor must have a mass balance that provides favourable economics when all reactor elements perform ideally. Therefore, the mass balance under ideal performance is best evaluated prior to scale up attempts, as its derivation does not require any experimental data and the results are required for determining the economic potential of a process. Consider a thought-experiment with a hypothetic ideal electrochemical reactor that has $100 \%$ Faraday efficiency (FE) at both electrodes and a $100 \%$ charge selective cation exchange membrane (CEM). The hypothetic reactor is aimed at the conversion of carbon dioxide to formic acid. The catholyte and anolyte respectively consist of aqueous solutions of $\mathrm{KHCO}_{3}$ and $\mathrm{H}_{2} \mathrm{SO}_{4}$, similar to some reactor designs used in literature 13,14. At the cathode, reduction of $\mathrm{CO}_{2}$ with protons to formic acid is considered (2.1), which is the targeted reaction in many recent publications ${ }^{1-4}$. For the anodic reaction, the oxygen evolution reaction (2.2) is selected. Figure 2.1 provides a schematic overview of the reactor.

Aqueous $\mathrm{KHCO}_{3}$ solution is a representative catholyte for studies towards the $\mathrm{CO}_{2}$ reduction reaction $(\mathrm{CO} 2 \mathrm{RR})$. The presence of bicarbonate $\left(\mathrm{HCO}_{3}{ }^{-}\right)$ions enhances the $\mathrm{CO} 2 \mathrm{RR}$ and provides a pH buffer ${ }^{5-7}$. In a $\mathrm{CO}_{2}$ saturated $\mathrm{KHCO}_{3}$ solution, $\mathrm{CO}_{2}$, bicarbonate and carbonate species are in equilibrium. Nearly all recent research focused on the CO2RR, including scaleup attempts ${ }^{13,15-19}$, is conducted in electrochemical cells that are divided by ion-exchange membranes ${ }^{5,6,20}$. The majority of CO2RR research is solely dedicated to the study of cathode and catholyte $5,7,21,22$. However, ion transfer across the membrane may shift the carbonaceous equilibrium and affect catholyte composition, $\mathrm{pH}$ and $\mathrm{CO}_{2}$ consumption, which in turn may have an effect on the electrochemistry at the electrode. Therefore, this chapter explores the effect of basic operating parameters (current and electrolyte flow), and membrane and anolyte choice on the composition of the catholyte, $\mathrm{pH}, \mathrm{CO}_{2}$ conversion and overall balance. 


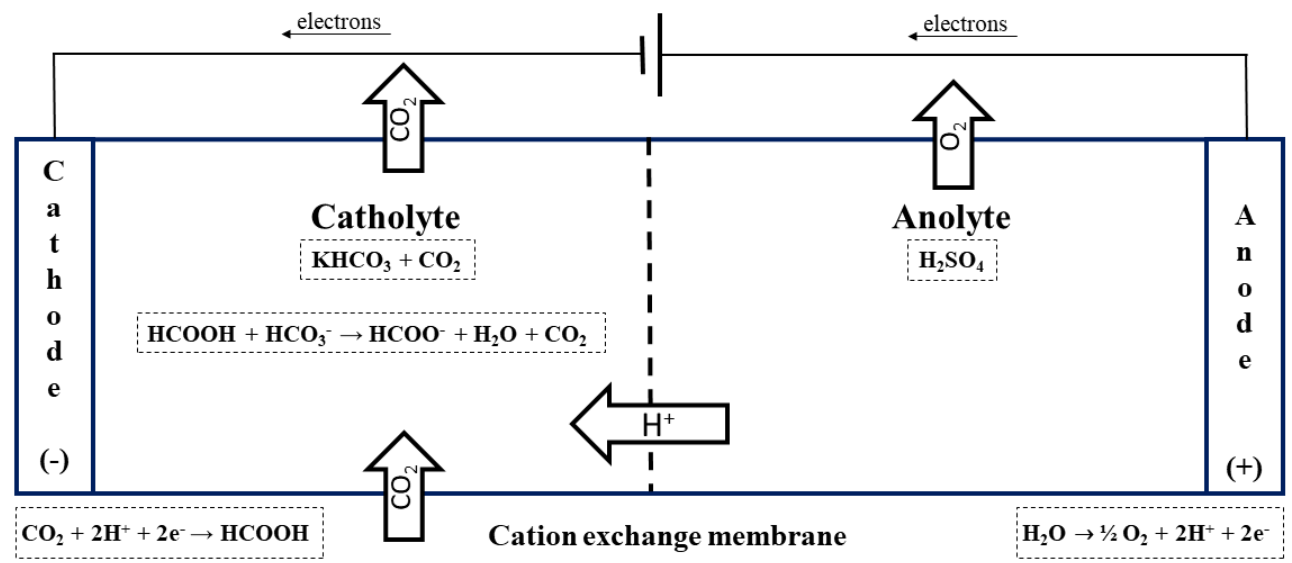

Figure 2.1: Schematic representation of an electrochemical reactor for the case: [Cathode $\left|\mathrm{CO}_{2}+\mathrm{KHCO}_{3}\right| \mathrm{CEM}\left|\mathrm{H}_{2} \mathrm{SO}_{4}\right|$ Anode].

Cathodic reaction:

$$
\mathrm{CO}_{2}+2 \mathrm{H}^{+}+2 e^{-} \rightarrow \mathrm{HCOOH}
$$

Anodic reaction:

$$
\mathrm{H}_{2} \mathrm{O} \rightarrow \frac{1}{2} \mathrm{O}_{2}+2 \mathrm{H}^{+}+2 e^{-}
$$

Initially, consider batch operation for both liquid electrolyte phases, which describes a typical $\mathrm{H}$-type electrochemical cell. The catholyte is assumed to be in constant equilibrium with pure gaseous $\mathrm{CO}_{2}$ at 1 bar. Any (gaseous) oxygen produced at the anode flows freely out of the reactor and does not accumulate. The respective electrolytes are assumed to be idealy mixed and no mass transport limitations are present. Therefore, no concentration gradients are present in the fluid phases. Accumulation of (mobile) ions in the membrane is neglected. Therefore, species transferred accros the membrane are directly available for reactions. This aproach regards all balances as quasi-stationairy.

First, the catholyte of the thought-experiment is considered, shown as the solid blue box in Figure 2.2. At $t>0$, sufficient potential is applied for the cathodic reaction (2.1) to occur. Due to the reaction, $\mathrm{CO}_{2}$ and protons are consumed and formic acid is produced. Simultaneously, an influx of electrons into the reaction products occurs at the cathode (2.3). For clarity, electron flux from/to an electrode and transfer of species across the membrane are shown between square brackets throughout this chapter. To satisfy the charge balance, protons transfer across the CEM to the catholyte (2.4).

Transport: $\quad\left[2 e^{-}\right]_{\text {cathode }} \rightarrow\left[2 e^{-}\right]_{\text {catholyte (in reaction products) }}$

$\left[2 \mathrm{H}^{+}\right]_{\text {anolyte }} \rightarrow\left[2 \mathrm{H}^{+}\right]_{\text {catholyte }}$ 


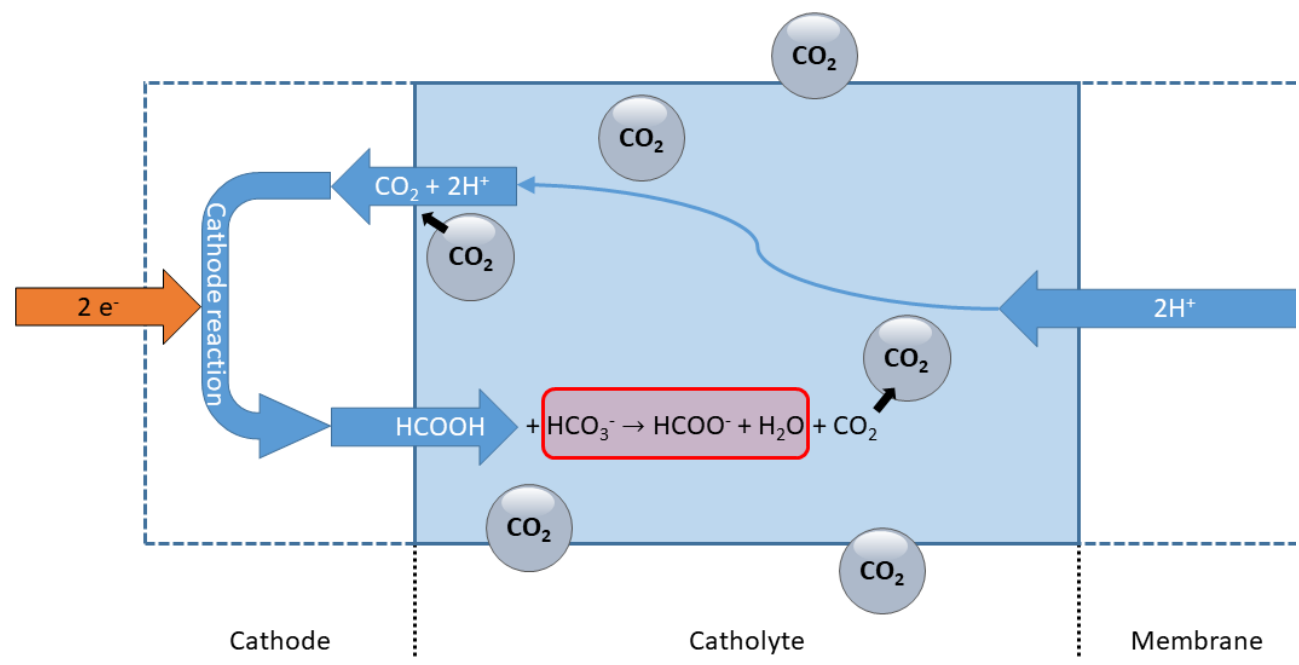

Figure 2.2: Schematic overview of reactions and transport in the catholyte.

Homogenous acid-base reactions must be considered. First, consider the reactants of the cathodic reaction. $\mathrm{CO}_{2}$ consumed in the cathode reaction is immediately resupplied from the gas phase and has no effect on the catholyte composition. The cathodic reaction also consumes two protons, which are resupplied by transfer across the membrane. Second, consider the product of the cathodic reaction. Formic acid has a $\mathrm{pK}_{\mathrm{a}}$ value of 3.75 whereas bicarbonate has $\mathrm{pK}_{\mathrm{a}}$ values of 6.35 and $10.33^{23}$. Therefore, the formic acid reacts with the bicarbonate via acid base reaction (2.5), to produce formate, water and $\mathrm{CO}_{2}$. Note that reaction (2.5) is the sum of several acid-base reaction steps, shown as reactions $(2.5 \mathrm{a}-2.5 \mathrm{c})$. The formed $\mathrm{CO}_{2}$ will transfer to the gas phase, as gas-liquid equilibrium is assumed.

Catholyte acid-base reaction: $\quad \mathrm{HCOOH}+\mathrm{HCO}_{3}^{-} \rightarrow \mathrm{HCOO}^{-}+\mathrm{H}_{2} \mathrm{O}+\mathrm{CO}_{2}$

$$
\begin{aligned}
& \mathrm{HCOOH} \rightarrow \mathrm{H}^{+}+\mathrm{HCOO}^{-} \\
& \mathrm{HCO}_{3}^{-}+\mathrm{H}^{+} \rightarrow \mathrm{H}_{2} \mathrm{CO}_{3} \\
& \mathrm{H}_{2} \mathrm{CO}_{3} \rightarrow \mathrm{H}_{2} \mathrm{O}+\mathrm{CO}_{2}
\end{aligned}
$$

Catholyte balance:

$$
\mathrm{HCO}_{3}^{-}\left[+2 \mathrm{H}^{+}+2 e^{-}\right] \Rightarrow \mathrm{HCOO}^{-}+\mathrm{H}_{2} \mathrm{O}
$$

Addition of all reactions in the catholyte $(2.1,2.5)$ and transports to the catholyte $(2.3,2.4)$, yield the catholyte balance (2.6). Species not between square brackets can be observed in the catholyte. Species that are between brackets were transported into the catholyte and immediately consumed, hence are not observed as such in the catholyte. The reaction of formic acid with bicarbonate to formate, $\mathrm{CO}_{2}$ and water results in the overall conversion of bicarbonate to formate. 
Next, consider the balance over the anolyte. In the anodic reaction (2.2), water is consumed and oxygen, protons and electrons are produced. Simultaneous with the anodic reaction, electrons flow from reactants in the anolyte, into the anode (2.7). Consequently, to satisfy the charge balance, protons are transported from the anolyte to the catholyte (2.4). Oxygen transfers to the gas phase and no acid-base reactions occur. The anolyte balance is shown as reaction equation 2.9, which is the sum of all reactions in and transports into the anolyte (2.2, 2.3, 2.7 and 2.8). Considering the balances over the catholyte (2.6) and anolyte (2.9) separately, water is produced in the catholyte and consumed from the anolyte. Therefore, there is net water transport from anolyte to catholyte, but this is not reflected in the overall cell balance 2.10 (the sum of equations 2.6 and 2.9). Anolyte, catholyte and overall balances must all be evaluated to identify internal transports and overall conversion.

Transport:

$\left[2 e^{-}\right]_{\text {anolyte (in reagents) }} \rightarrow\left[2 e^{-}\right]_{\text {anode }}$

Anolyte acid-base reaction:

Anolyte balance:

$$
\mathrm{H}_{2} \mathrm{O} \Rightarrow \frac{1}{2} \mathrm{O}_{2}\left[+2 \mathrm{H}^{+}+2 e^{-}\right]
$$

Overall cell balance:

$$
\mathrm{HCO}_{3}^{-} \rightarrow \mathrm{HCOO}^{-}+\frac{1}{2} \mathrm{O}_{2}
$$

Now assume that the hypothetical batch reactor initially contains 1 mole/ $\mathrm{LHCO}_{3}$ solution. When all bicarbonate is consumed, acid-base reaction 2.5 can no longer occur. If the cathodic reaction is continued, the produced formic acid is not able to participate in acid-base reactions any more (formic acid is not acidic enough to protonate water in significant amounts). When no bicarbonate is present, the catholyte balance will therefore be the addition of reaction 2.1 and equations 2.3 and 2.4, shown as equation 2.11. The overall balance is shown as equation 2.12 .

$$
\begin{array}{lll}
\text { Catholyte balance: } & \mathrm{CO}_{2}\left[+2 \mathrm{H}^{+}+2 e^{-}\right] \Rightarrow \mathrm{HCOOH} & \left\{\mathrm{C}_{\mathrm{HCO}_{3}^{-}}=0 \text { mole } / \mathrm{L}\right\} \\
\text { Overall cell balance: } & \mathrm{CO}_{2}+\mathrm{H}_{2} \mathrm{O} \rightarrow \mathrm{HCOOH}+\frac{1}{2} \mathrm{O}_{2} \quad\left\{\mathrm{C}_{\mathrm{HCO}_{3}^{-}}=0 \text { mole } / \mathrm{L}\right\}
\end{array}
$$

Overall balance (2.10) shows that a $\mathrm{CO}_{2}$ electrolyzer using acidic anolyte, a cation exchange membrane and a $\mathrm{CO}_{2}+$ bicarbonate catholyte does not actually convert $\mathrm{CO}_{2}$ to formate, due to the acid-base reactions that occur. The actual overall reactant is bicarbonate, instead of $\mathrm{CO}_{2}$. However, when no (more) bicarbonate is present, that same set-up allows for the net production of formic acid from $\mathrm{CO}_{2}$ in a formate/formic acid catholyte, as described by overall cell balance 2.12. Several studies reporting on the conversion of $\mathrm{CO}_{2}$ to formic acid/formate under inappropriate conditions ${ }^{13,14,24}$, are actually studying the overall conversion of their supporting electrolyte: potassium/sodium bicarbonate. 


\section{Table 2.1: Algorithm for deriving a mass balance and assumptions for the simplified method}

\begin{tabular}{ll}
\hline Step & Assumptions in simplified method \\
\hline Definition of electrochemical reactor & \\
\hline Select electrode reactions & $100 \%$ Faraday efficiency \\
Select electrolytes & No mass transport limitations \\
& $100 \%$ electrolyte purity \\
& Gas and liquid are in vapour liquid equilibrium (VLE) \\
& Constant density of liquid \\
Select membrane & $100 \%$ charge selective membrane \\
\hline Identification of homogenous reactions and transports \\
\hline Identify charge carrier and account for its & All ionic current is carried by one charge carrier \\
transport & No accumulation of mobile ions in the membrane \\
& Ideal mixing \\
& No mass transport limitations \\
& Water transport through the membrane is negligeble \\
& Dissolved gasses do not transfer throught the \\
membrane \\
Identify and account for homogenous & Irreversible reactions \\
reactions & Homogenous reactions are instantaneous \\
& No mass transport limitations \\
Identify limitations & Homogenous reactions proceed to complete \\
& conversion of the limiting reactant \\
\hline Processing & \\
\hline Derive balances per electrolyte & \\
\hline
\end{tabular}

\subsection{Simplified method for mass balance evaluation}

In the previous section, an overall cell balance was derived in several steps, which are summarized in Table 2.1. To estimate the mass balance without the need for detailed calculations, several assumptions can be made, also summarized in Table 2.1. The relevant steps and assumptions can be applied to any reactor, which yields an estimate of the overall cell balance, electrolyte balances and internal transports. From here on, this is referred to as the simplified method. To derive a more detailed mass balance, assumptions can be replaced with an appropriate mathematical description. Thereby the simplified method provides guidance for detailed modelling.

For identification of the charge carrier, it holds that higher concentration and ion mobility increase the contribution of an ionic species to the ionic current ${ }^{25}$. This is especially relevant to some studies that employ a Nafion ${ }^{\mathrm{TM}}$ proton exchange membrane (PEM) and assume that it only conducts protons, even when the anolyte is highly alkaline ${ }^{19,26}$. However, a Nafion ${ }^{\mathrm{TM}}$ 
PEM is a type of CEM (although optimised for proton transport) and will transport other cations (e.g. $\mathrm{K}^{+}$) when proton availability is too low. ${ }^{27}$ Lastly, the validity limits of the solutions should be identified, as limitations can occur through e.g. a reactant reaching $100 \%$ conversion or reaching a solubility limit.

\subsection{Application to: Cathode $\left|\mathrm{CO}_{2}+\mathrm{KHCO}_{3}\right| \mathrm{CEM}\left|\mathrm{H}_{2} \mathrm{SO}_{4}\right|$ Anode}

The balances derived in the thought-experiment can be used to visualize the concentration of selected species and the consumption of $\mathrm{CO}_{2}$ as reactions progress. To make this analysis independent of reactor type and size, consider the charge that has been passed through a unit volume of electrolyte (Coulomb per litre) and define the electrochemical productivity (R) as such. For a batch reactor, the electrochemical productivity in electrolyte $\mathrm{j}$ is defined in equation 2.13. With this definition a reactor that contains $1 \mathrm{~L}$ catholyte and is operated at 10 A for 10 minutes, has the same electrochemical productivity as a reactor that e.g. contains $0.1 \mathrm{~L}$ catholyte and is operated at $2 \mathrm{~A}$ for 5 minutes. Furthermore, the electrochemical productivity is fully defined by parameters that can be measured and controlled ex-situ, which makes it useful for practical applications.

$R_{\text {batch }}^{j}=\int_{0}^{t} \frac{1}{V^{j}} d t$

Consider an ideally stirred batch reactor with a control system to keep the gaseous $\mathrm{CO}_{2}$ pressure at 1 bar in the catholyte. Initial conditions are: $1 \mathrm{M} \mathrm{KHCO}_{3}$ catholyte and $1 \mathrm{M} \mathrm{H}_{2} \mathrm{SO}_{4}$ anolyte. The change in catholyte composition is described by equations 2.6 and 2.11 , for which the results are plotted in Figure 2.3 and Figure 2.4A (See appendix for algebraic equations A2.1-A2.3). The figures can be divided into two electrochemical productivity domains: domain I, from 0 to 193 kiloCoulomb per litre when there is bicarbonate present and domain II from 193 to $600 \mathrm{kC} / \mathrm{L}$ when all bicarbonate has reacted. This is illustrated in Figure 2.3. In domain I, bicarbonate is converted to formate as per equation 2.6, whereas in domain II, $\mathrm{CO}_{2}$ is converted to formic acid as per equation 2.11. This is further illustrated by Figure 2.4A, where $\mathrm{CO}_{2}$ consumption starts from domain II. Catholyte compositions and $\mathrm{pH}$ change continuously with time in the batch system considered. 


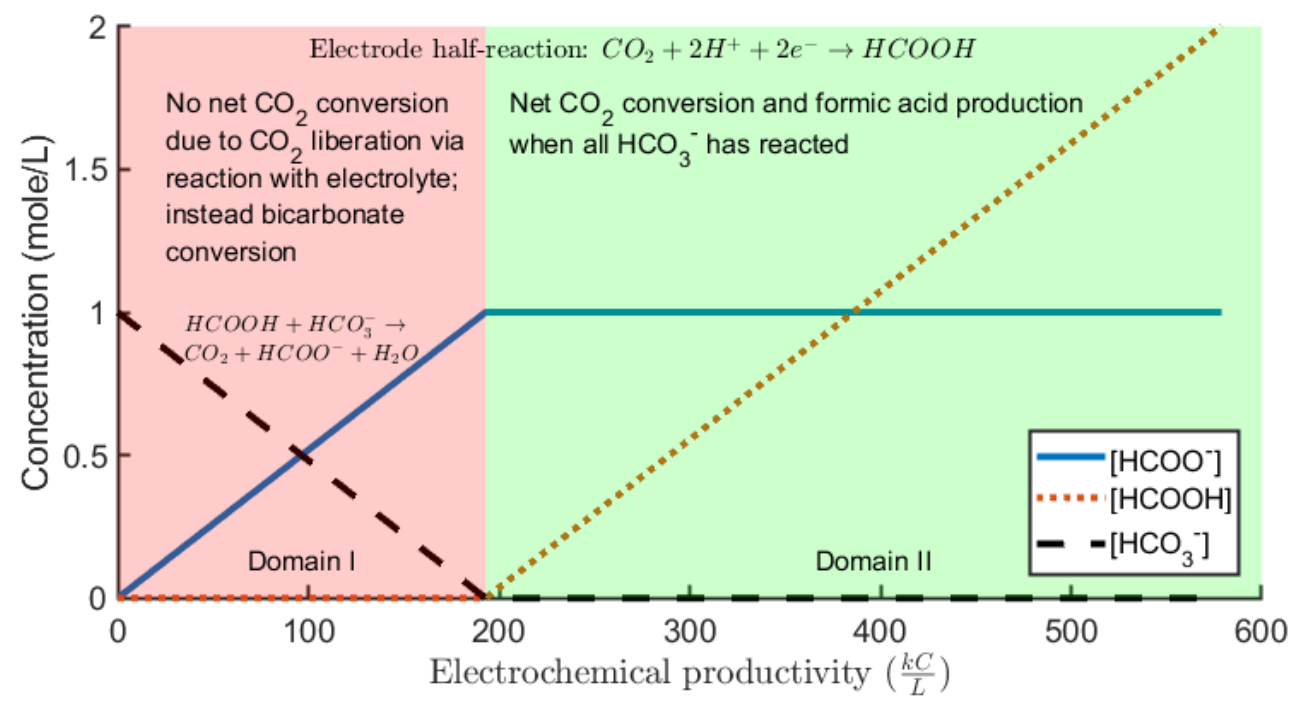

Figure 2.3: Concentration of selected species in catholyte using the simplified method for system: $\quad\left[\right.$ Cathode $\left|\mathrm{CO}_{2}+\mathrm{KHCO}_{3}\right| \mathrm{CEM}\left|\mathrm{H}_{2} \mathrm{SO}_{4}\right|$ Anode $]$.

The same system was also modelled using acid-base equilibrium calculations in the catholyte (See appendix section A2.2). The results of this extended method are shown in Figure A2.1 (appendix) and resemble the simplified method results very closely, showing the strength of the simplified method. Unlike the simplified method, the extended model can also predict $\mathrm{pH}$, which is shown in Figure 2.4B for the thought-experiment. In domain I, the buffer effect of bicarbonate is clearly visible. When domain II is reached, $\mathrm{pH}$ drops as the reaction medium now resembles a formic acid/formate solution.

Figures 2.3 and 2.4 are constructed for a hypothetical batch system, whereas an industrially relevant process will use a flow reactor. Such a process may show mixing behaviour ranging between that of a plug flow reactor (PFR) to a continuous ideally stirred tank reactor (CSTR). For a CSTR it is shown in appendix section A2.3 that the steady state concentration follows equation 2.14. The electrochemical productivity is defined in equation 2.15 , based on the volumetric flow through the reactor. The transport number of ion $i$ is defined in equation 2.16 and represents the fraction of the total ionic current, carried by species i. Equation 2.14 is a simplification of equation A2.22 (appendix) and assumes constant density. 

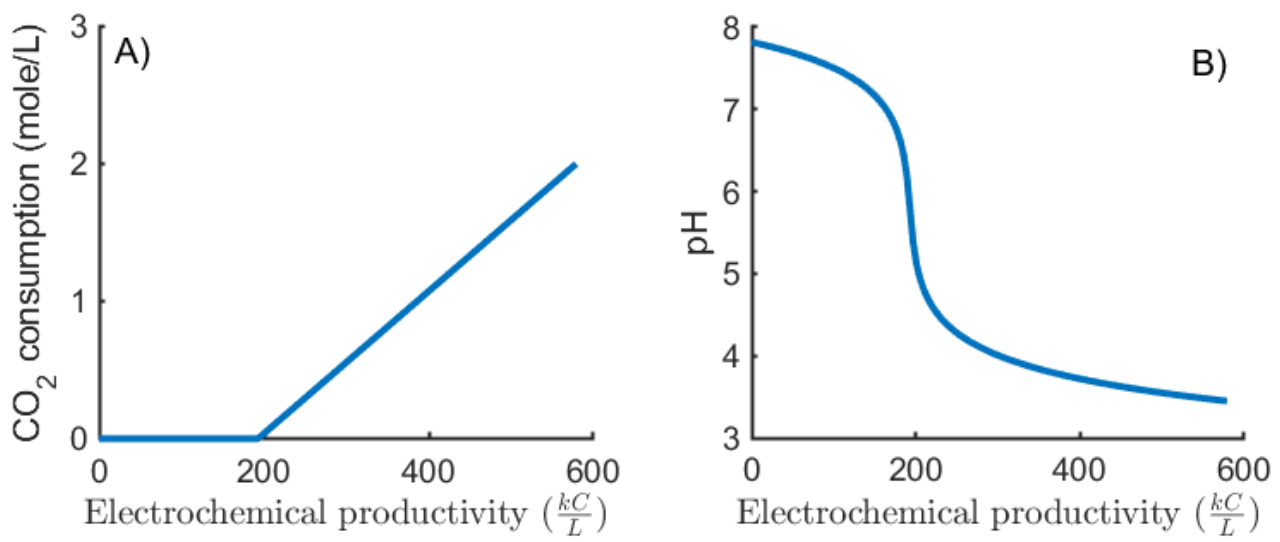

Electrochemical productivity $\left(\frac{k C}{L}\right)$

Figure 2.4: A) $\mathrm{CO}_{2}$ consumption as function of electrochemical productivity using the simplified method. B) pH change as function of electrochemical productivity using acid-base equilibrium calculations in the catholyte. Both for system: [Cathode | $\mathrm{CO}_{2}+\mathrm{KHCO}_{3}|\mathrm{CEM}| \mathrm{H}_{2} \mathrm{SO}_{4} \mid$ Anode].

The terms $f_{i}^{c} \frac{n F}{I}, \overline{t_{i}} \frac{n}{z_{i}}$ and $v_{i}^{c}$ are all dimensionless as shown in equations 2.17, 2.18 and 2.19. With the assumptions of the simplified method, those terms are also constant and independent of mixing. E.g. for protons in the catholyte, equation 2.17 equals zero, as there is no exchange with the gas phase, equation 2.18 equals 2 , as obtained from equation 2.4 and equation 2.19 equals -2 , as obtained from equation 2.1. Since all parameters in equation 2.14 are independent of mixing, modelling yields results that are identical to those in Figure 2.3 and Figure 2.4. Therefore, Figures 2.3 and 2.4 also hold for CSTR behaviour and visualize possible operating points for a CSTR with $1 \mathrm{M} \mathrm{KHCO} 3+\mathrm{CO}_{2}$ as catholyte feed.

$$
\begin{aligned}
& c_{i, \text { in }}^{c}-c_{i}^{c}+\left(f_{i}^{c} \frac{n F}{I}+\overline{t_{i}} \frac{n}{z_{i}}+v_{i}^{c}\right) \frac{R_{\text {flow }}^{c}}{n F}=0 \\
& R_{\text {flow }}^{j}=\frac{I}{\phi_{V}^{j}} \\
& \overline{t_{i}}=\frac{z_{i} J_{i}}{\sum_{i} z_{i} J_{i}} \\
& f_{i}^{c} \frac{n F}{I}=\frac{f_{i}^{c}}{\left(\frac{I}{n F}\right)}=\frac{\text { Transport of species } i \text { from gas to electrolyte }[\text { mole } / \mathrm{s}]}{\text { Rate of cathodic reaction }[\text { mole } / \mathrm{s}]} \\
& \bar{t}_{i} \frac{n}{z_{i}}=\frac{z_{i} J_{i}}{\sum_{i} z_{i} J_{i}} \frac{n}{z_{i}}=\frac{J_{i}}{\left(\frac{I}{n F}\right)}=\frac{\text { Transfer of species } i \text { across the membrane }[\text { mole } / s]}{\text { Rate of cathodic reaction }[\text { mole } / \mathrm{s}]} \\
& v_{i}^{c}=\frac{\text { Rate of production of species } i[\text { mole } / \mathrm{s}]}{\text { Rate of cathodic reaction }[\text { mole } / \mathrm{s}]}
\end{aligned}
$$


With the assumption in Table 2.1, the plug in a PFR, may be seen as a batch reactor moving through a tube. Therefore, Figures 2.3 and 2.4 also hold for PFR behaviour. More general, when the Faraday efficiency, $\overline{t_{i}}$ and $f_{i}^{c} / I$ are independent of concentration, then the overall balance is not influenced by mixing behaviour. In practical situations this could happen when the electrode reactions are highly selective and only one ionic species can be transported through the membrane, for example in the case of PEM water electrolysis. Examples where the transport of species through the membrane is a function of productivity are described in the supporting information of the paper corresponding to this chapter. ${ }^{28}$ In those cases, $\overline{t_{i}}$ is dependent on concentration, hence on the degree of mixing. Any attempt of modelling this type of electrolyzer would require a mathematic model that describes $\overline{t_{i}}$ as a function of concentration.

For any production process, the concentration of products at the outlet of the reactor needs to be significant, to have meaningful production and allow for easy separation or storage. When the goal is to produce formate from bicarbonate, the reactor should be operated at the righthand side of domain I. The electrolyte then closely resembles a formate solution with some bicarbonate, in at least a part of the reactor. When the goal is to produce formic acid from $\mathrm{CO}_{2}$, the reactor must be operated in domain II. The catholyte must then be formate/formic acid solution, without bicarbonate. Both industrially relevant electrolyte compositions are vastly different from the almost pure (potassium) bicarbonate solutions currently used in literature. ${ }^{5-7}$ Therefore, promising electro-catalysts should also be validated under industrially relevant conditions, which resemble the desired reactor output.

\section{What happens when $\mathrm{HCO}_{3}{ }^{-}$is the reactive species?}

Since the reduction of $\mathrm{CO}_{2}$ at the cathode does not necessarily result in an overall mass balance wherein $\mathrm{CO}_{2}$ is consumed, the question arises what the overall balance would be if bicarbonate were the reactive species. Table 2.2 shows the relevant balances for the same electrolyzer as before, where the cathodic reaction is changed to electro-reduction of bicarbonate (2.20). Protons are still transported through the membrane (2.21) and also the anodic reaction remains unchanged (2.21). In the catholyte, hydroxide is generated via reaction 2.20, whilst protons are transported to the catholyte (2.21). Therefore, those will react to form water via reaction 2.23. No acid-base reactions occur in the anolyte (2.24). The resulting catholyte, anolyte and overall balances $(2.25,2.26$ and 2.27$)$ are identical to those of the $\mathrm{CO}_{2}$ electrolyzer (2.6, 2.9 and 2.10). Another perspective is regarding $\mathrm{HCO}_{3}{ }^{-}$as $\mathrm{CO}_{2}+\mathrm{OH}^{-}$. Therefore, due to the $\mathrm{CO}_{2}-\mathrm{HCO}_{3}{ }^{-}-\mathrm{CO}_{3}{ }^{2-}$ equilibrium, the overall conversion of an electrolyzer with $\mathrm{CO}_{2}+\mathrm{KHCO}_{3}$ as catholyte does not depend on $\mathrm{CO}_{2}$ or $\mathrm{HCO}_{3}{ }^{-}$being the reactive species. 


\section{Table 2.2: Mass balance for a $\mathrm{HCO}_{3}^{-}$electrolyzer with cation exchange membrane and acidic anolyte.}

\begin{tabular}{ll}
\hline Cathode $\left|\mathrm{KHCO}_{3}\right| \mathrm{CEM}\left|\mathrm{H}_{2} \mathrm{SO}_{4}\right|$ Anode \\
Cathodic reaction & $\mathrm{HCO}_{3}^{-}+\mathrm{H}_{2} \mathrm{O}+2 e^{-} \rightarrow \mathrm{HCOO}^{-}+2 \mathrm{OH}^{-}$ \\
Transport & $2 \mathrm{H}_{\text {anolyte }}^{+} \rightarrow 2 \mathrm{H}_{\text {catholyte }}^{+}$ \\
Anodic reaction & $\mathrm{H}_{2} \mathrm{O} \rightarrow \frac{1}{2} \mathrm{O}_{2}+2 \mathrm{H}^{+}+2 e^{-}$ \\
Catholyte acid-base reaction & $2 \mathrm{OH}^{-}+2 \mathrm{H}^{+} \rightarrow 2 \mathrm{H}_{2} \mathrm{O}$ \\
Anolyte acid-base reaction & - \\
\hline Catholyte balance & $\mathrm{HCO}_{3}^{-}\left[+2 \mathrm{H}^{+}+2 e^{-}\right] \rightarrow \mathrm{HCOO}^{-}+\mathrm{H}_{2} \mathrm{O}$ \\
Anolyte balance & $\mathrm{H}_{2} \mathrm{O} \rightarrow \frac{1}{2} \mathrm{O}_{2}\left[+2 \mathrm{H}^{+}+2 e^{-}\right]$ \\
Overall balance & $\mathrm{HCO}_{3}^{-} \rightarrow \mathrm{HCOO}^{-}+\frac{1}{2} \mathrm{O}_{2}$
\end{tabular}

\subsection{Application to: Cathode $\left|\mathrm{CO}_{2}+\mathrm{KHCO}_{3}\right| \mathrm{CEM}|\mathrm{KOH}|$ Anode}

A factor that does influence the overall balance is the anolyte. To illustrate the importance of anolyte choice, again consider a $\mathrm{CO}_{2}$ electrolyzer, but with alkaline $(\mathrm{KOH})$ anolyte instead of acidic ${ }^{15-18}$, shown in Table 2.3. As a result, the ionic species that is transported through the membrane changes from $\mathrm{H}^{+}$to $\mathrm{K}^{+}$. The protons required in the cathodic reaction (2.1) are now not supplied via transfer across the membrane, but must be supplied from the catholyte. Half of the required protons are supplied via deprotonation of the produced formic acid and the other half via water dissociation to $\mathrm{H}^{+}$and $\mathrm{OH}^{-}$. All hydroxide ions are consumed by a reaction with dissolved $\mathrm{CO}_{2}$, to produce $\mathrm{HCO}_{3}{ }^{-}$. Resulting balances are shown as equation 2.28, 2.29 and 2.30. The use of an alkaline anolyte results in double the stoichiometric $\mathrm{CO}_{2}$ consumption and two to one consumption of $\mathrm{OH}^{-}$. Hence, a simple change in anolyte can drastically alter the overall mass balance of an electrochemical system. Moreover, this system is not advised for the conversion of $\mathrm{CO}_{2}$ to products, due to the inherent amount of sideproducts and excessive $\mathrm{KOH}$ consumption. 
Table 2.3: Mass balance for a $\mathrm{CO}_{2}$ electrolyzer with cation exchange membrane and alkaline anolyte.

\begin{tabular}{ll}
\hline Cathode $\left|\mathrm{CO}_{2}+\mathrm{KHCO}_{3}\right| \mathrm{CEM}|\mathrm{KOH}|$ Anode \\
Catholyte balance & $2 \mathrm{CO}_{2}+\mathrm{H}_{2} \mathrm{O}\left[+2 \mathrm{~K}^{+}+2 e^{-}\right] \Rightarrow \mathrm{HCOO}^{-}+\mathrm{HCO}_{3}^{-}+2 \mathrm{~K}^{+}$ \\
Anolyte balance & $2 \mathrm{KOH} \Rightarrow \frac{1}{2} \mathrm{O}_{2}+\mathrm{H}_{2} \mathrm{O}\left[+2 \mathrm{~K}^{+}+2 e^{-}\right]$ \\
Overall balance & $2 \mathrm{CO}_{2}+2 \mathrm{KOH} \rightarrow \mathrm{HCOOK}+\mathrm{KHCO}_{3}+\frac{1}{2} \mathrm{O}_{2}$
\end{tabular}

The concentration vs electrochemical productivity profiles for a reactor design with alkaline anolyte are shown in Figure 2.5. Results are for $1 \mathrm{M} \mathrm{KHCO}_{3}+\mathrm{CO}_{2}(\mathrm{~g})$ catholyte and assuming $\mathrm{KOH}$ supply is not limiting at the anode. The $\mathrm{K}^{+}$concentration rises in a two to one molar ratio compared to formate, due to the transfer across the membrane. The unwanted production of $\mathrm{HCO}_{3}{ }^{-}$is observed as a rise in concentration with electrochemical productivity. Because no reactant reaches $100 \%$ conversion, there is no separation of domains. A realistic operating point in this set-up would be at significant $\mathrm{K}^{+}$and $\mathrm{HCO}_{3}{ }^{-}$concentrations, approaching the solubility limit of $\mathrm{KHCO}_{3}$. Formate concentration can therefore not exceed $0.96 \mathrm{~mole} / \mathrm{L}$ for the feed considered. Concluding, changing something as seemingly meaningless as the anolyte in a $\mathrm{CO}_{2}$ electro-conversion system, can result in a drastic change in overall balances, electrolyte compositions, possible operating points and ultimately, reactor design feasibility.

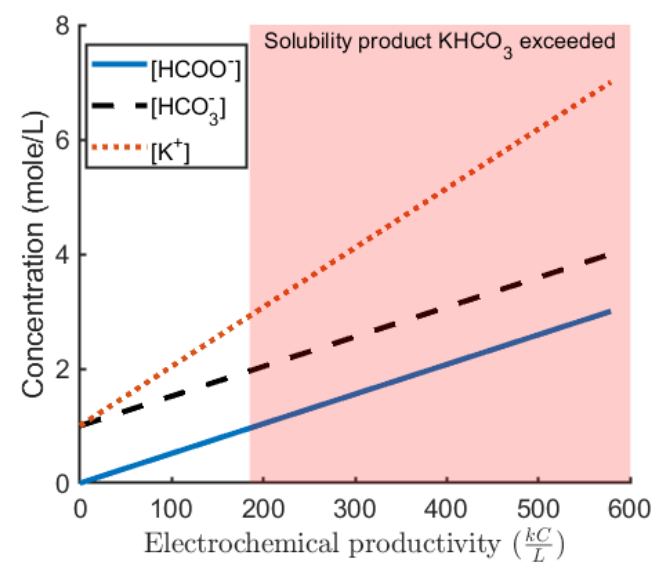

Figure 2.5: Concentration of selected species in the catholyte as function of electrochemical productivity for the system: [Cathode $\left|\mathrm{CO}_{2}+\mathrm{KHCO}_{3}\right| \mathrm{CEM} \mid$ KOH | Anode].

\subsection{Application to: Cathode $\left|\mathrm{CO}_{2}+\mathrm{KHCO}_{3}\right| \mathrm{BPM}|\mathrm{KOH}|$ Anode}

In the previous analysis it was observed that an alkaline anolyte in combination with a cation exchange membrane does not yield a favourable overall mass balance. Moreover, an anion exchange membrane (in combination with any anolyte) never results in a favourable mass 
balance, as it does not block $\mathrm{HCOO}^{-}$transport, hence cannot prevent $\mathrm{HCOO}^{-}$oxidation at the anode. However, from a construction viewpoint, it would be beneficial to have alkaline conditions at the anode, as acidic conditions require titanium (coated) cell components, whereas cheeper stainless steel or nickel suffices in alkaline conditions. ${ }^{29-31}$ Moreover, the oxygen evolution reaction proceeds at less overpotential in alkaline conditions and nonnoble-metal catalysts are, to-date, only stable in alkaline conditions. ${ }^{32,33}$ These conditions could be realized by utilizing a bipolar membrane (BPM) ${ }^{34}$ Therefore, the balance over an electrolyzer with BPM and alkaline anolyte is constructed.

In a bipolar membrane, a cation exchange membrane and anion exchange membrane are sandwiched together. When exposed to a sufficiently strong electric field, water at the interface between the cation and anion exchange layers (CEL and AEL) can form protons and hydroxide ions, which are transported through the CEL and AEL respectively. Protons could then be consumed at the cathodic reaction and anions at the anodic reaction. ${ }^{35}$ Bipolar membranes are more suitable to maintain $\mathrm{pH}$ gradients over the membrane than regular membranes. ${ }^{34,36}$ E.g. through a CEM, $\mathrm{H}^{+}$from the anolyte may exchange for $\mathrm{K}^{+}$from the catholyte, resulting in undesired transports. However, in a BPM that exchange path is blocked by the anion exchange layer.

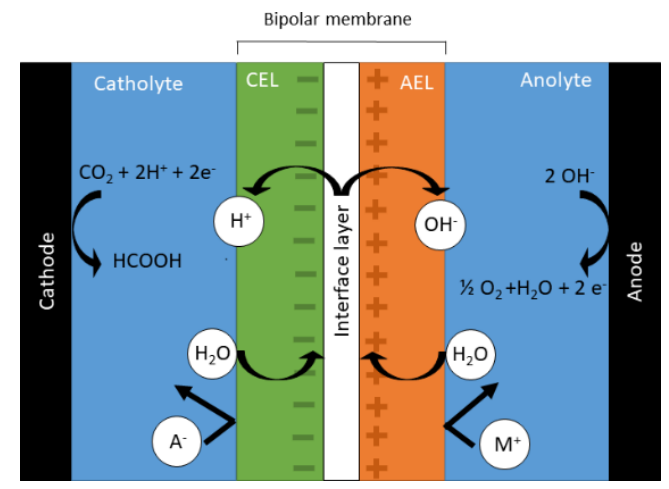

Figure 2.6: Schematic representation of an electrochemical reactor for the case: [Cathode | $\mathrm{CO}_{2}+\mathrm{KHCO}_{3}|\mathrm{BPM}| \mathrm{KOH} \mid$ Anode].

Figure 2.6 shows a schematic representation of an electrolyzer with bipolar membrane. The mass balance is evaluated in Table 2.4, under the assumption that water transport to the membrane occurs in equal amounts from anolyte and catholyte. The overall balance (2.40) yields a favourable conversion, namely from bicarbonate to formate and oxygen. By utilising a bipolar membrane, favourable conversion can be realised under optimal catholyte and anolyte conditions. Therefore, bipolar membranes should be considered for electrochemical bicarbonate to formate conversion systems. Cation exchange membranes should not yet be discarded, but the potential advantages of bipolar membranes appear significant. 


\section{Table 2.4: Short-cut mass balance results for a $\mathrm{CO} 2$ electrolyzer with bipolar membrane and alkaline anolyte.}

\begin{tabular}{|c|c|c|}
\hline \multicolumn{3}{|c|}{ Cathode $\left|\mathrm{KHCO}_{3}+\mathrm{CO}_{2}\right| \mathrm{CEM} \mid$ interface layer $|\mathrm{AEM}| \mathrm{KOH} \mid$ Anode } \\
\hline Cathodic reaction & $\mathrm{CO}_{2}+2 \mathrm{H}^{+}+2 e^{-} \rightarrow \mathrm{HCOOH}$ & $(2.31)$ \\
\hline Transport CEM & $\begin{array}{l}2 \mathrm{H}_{\text {inter }}^{+} \rightarrow 2 \mathrm{H}_{\text {catholyte }}^{+} \\
\mathrm{H}_{2} \mathrm{O}_{\text {catholyte }} \rightarrow \mathrm{H}_{2} \mathrm{O}_{\text {inter }}\end{array}$ & $(2.32)$ \\
\hline Membrane interface reaction & $2 \mathrm{H}_{2} \mathrm{O} \rightarrow 2 \mathrm{H}^{+}+2 \mathrm{OH}^{-}$ & $(2.33)$ \\
\hline Transport AEM & $\begin{array}{l}2 \mathrm{OH}_{\text {inter }}^{-} \rightarrow 2 \mathrm{OH}_{\text {anolyte }}^{-} \\
\mathrm{H}_{2} \mathrm{O}_{\text {anolyte }} \rightarrow \mathrm{H}_{2} \mathrm{O}_{\text {inter }}\end{array}$ & $(2.34)$ \\
\hline Anodic reaction & $2 \mathrm{OH}^{-} \rightarrow \frac{1}{2} \mathrm{O}_{2}+\mathrm{H}_{2} \mathrm{O}+2 e^{-}$ & $(2.35)$ \\
\hline Catholyte acid-base reaction & $\mathrm{HCO}_{3}^{-}+\mathrm{HCOOH} \rightarrow \mathrm{HCOO}^{-}+\mathrm{H}_{2} \mathrm{O}+\mathrm{CO}_{2}$ & $(2.36)$ \\
\hline Anolyte acid-base reaction & - & $(2.37)$ \\
\hline Catholyte balance & $\mathrm{HCO}_{3}^{-}\left[+2 \mathrm{H}^{+}+2 e^{-}\right] \rightarrow \mathrm{HCOO}^{-}\left[+\mathrm{H}_{2} \mathrm{O}\right]$ & $(2.38)$ \\
\hline Anolyte balance & {$\left[2 \mathrm{OH}^{-}\right] \rightarrow \frac{1}{2} \mathrm{O}_{2}\left[+\mathrm{H}_{2} \mathrm{O}+2 e^{-}\right]$} & $(2.39)$ \\
\hline Overall balance & $\mathrm{HCO}_{3}^{-} \rightarrow \mathrm{HCOO}^{-}+\frac{1}{2} \mathrm{O}_{2}$ & $(2.40)$ \\
\hline
\end{tabular}

\subsection{Discussion}

Out of many possible options for reactor operation regarding electrochemical reduction of $\mathrm{CO}_{2} / \mathrm{HCO}_{3}{ }^{-}$to formic acid/formate, the most common examples were analysed. Many others are analysed in the supporting information of the publication corresponding to this chapter. ${ }^{28}$ All operation methods with a bicarbonate-based catholyte produce formate in the catholyte, due to an acid base reaction with formic acid. Reactor operation employing an AEM allows crossover of the negatively charged formate, which subsequently oxidises at the anode. The use of a CEM with acidic anolyte results in the conversion of bicarbonate to formate and oxygen, regardless whether $\mathrm{CO}_{2}$ or $\mathrm{HCO}_{3}{ }^{-}$is the electrochemically active species. The same reactor with alkaline anolyte, results in to conversion of $\mathrm{CO}_{2}$ and $\mathrm{OH}^{-}$to bicarbonate, formate and oxygen. The latter operation method is the only one that allows $\mathrm{CO}_{2}$ consumption in the presence of $\mathrm{HCO}_{3}{ }^{-}$whilst preventing product crossover. However, the consumption of 2:1 hydroxide to formate diminishes the economic potential of such $\mathrm{CO}_{2}$ conversion processes ${ }^{20}$. Therefore, scale-up attempts using these reactor operation methods ${ }^{13,15-18}$ have a low likelihood of commercial development.

Commercially attractive electrochemical reduction of $\mathrm{CO}_{2}$ to formate requires different catholyte from that described in the examples, to which the simplified method provides guidance. As shown with equations 2.11 and 2.12, the acid-base reaction between $\mathrm{HCOOH}$ and $\mathrm{HCO}_{3}{ }^{-}$prevents the desired conversion. Therefore, a reactor with: 1) catholyte that does not participate in acid-base reactions with formic acid; 2) a cation exchange membrane and 
3) acidic anolyte, results in overall $\mathrm{CO}_{2}$ conversion to formic acid. E.g. Aqueous $\mathrm{KCl}$ or $\mathrm{K}_{2} \mathrm{SO}_{4}$ electrolyte as described by Wu et al. ${ }^{2}$ would result in overall conversion of $\mathrm{CO}_{2}$ and water to formic acid and oxygen. The same conversion may also be achieved by e.g. using two membranes, as demonstrated by Hongzhou et al. ${ }^{37}$, using solid polymer electrolytes as demonstrated by Aeshala et al. ${ }^{38}$ or using a bipolar membrane. In all cases, the catholyte differs significantly from the potassium bicarbonate electrolyte used in most electro-catalysis studies ${ }^{5,6}$. Therefore, promising electrocatalysts should also be studied at industrially representative operating conditions and the simplified method is useful to identify those conditions.

Conclusions drawn in sound electrocatalysis studies, using bicarbonate-based catholyte remain valid. However, when interpreting these results for further process development, it is important to consider the electrolyte condition under which these results were obtained. At high electrochemical productivity, the composition and $\mathrm{pH}$ of the electrolyte change, depending on reactor operation, as shown in Figures 2.3, 2.4 and 2.5. That likely influences the performance of the electrocatalysts, which is highly dependent on the composition and $\mathrm{pH}$ of the catholyte. ${ }^{39}$ Moreover, the reversible cell potential, calculated via the Gibbs free energy of reaction is dependent on the overall cell balance. Therefore, the overall cell balance should be known, before energy efficiency can be calculated.

\subsection{Conclusion}

This chapter posed the question what the overall mass balance is for proposed electrochemical $\mathrm{CO}_{2} / \mathrm{HCO}_{3}^{-}$to formic acid/formate conversion systems using aqueous bicarbonate-based catholyte. To that end a simplified method for structured mass balance analyses was developed. The analysis shows that the overall balance this is not a simple addition of the relevant half-reactions. Transport of species through ion-selective membranes and (homogenous) acid-base reactions, make the overall balance dependent on the combination of electrolytes and membrane. In all cases employing a bicarbonate-based catholyte and a cation exchange membrane, the overall balance is not the conversion of $\mathrm{CO}_{2}$ and water to formic acid and oxygen. With acidic anolyte, bicarbonate is converted to formate and oxygen. With alkaline anolyte, $\mathrm{CO}_{2}$ and $\mathrm{OH}^{-}$are converted to $\mathrm{HCOO}^{-}, \mathrm{HCO}_{3}{ }^{-}$and $\mathrm{O}_{2}$. Neither case has favourable economics for electrochemical $\mathrm{CO}_{2}$ reduction. Several examples of reactor operation do result in the conversion of $\mathrm{CO}_{2}$ to $\mathrm{HCOOH}$ and $\mathrm{O}_{2}$. The main requirements are that the catholyte may not participate in acid-base reactions with formic acid and that protons must be transferred via the membrane to the catholyte. In all cases, the reaction conditions differ vastly from the almost pure potassium bicarbonate electrolyte that is used in many catalysis-oriented studies. Therefore, evaluation of those catalysts at industrially relevant conditions, identified with the method presented in this chapter, is necessary.

Considering the aim of this thesis, converting bicarbonate to formate, the results paint an optimistic picture. Mass balance analyses yielded a set of conditions that result in overall conversion of bicarbonate to formate, even when bicarbonate is not necessarily the electrochemically active species. Namely, when the catholyte contains bicarbonate and the 
membrane transfers only protons to the catholyte. In that case, the overall balance is conversion of bicarbonate to formate and oxygen. The most promising setup for this incorporates a $\mathrm{KHCO}_{3}$ catholyte, a bipolar membrane and $\mathrm{KOH}$ anolyte. Those conditions are favourable for both overall bicarbonate conversion and efficient oxygen evolution. Under overall bicarbonate conversion conditions, as a result of the carbonaceous equilibrium reactions, the mass balance is independent of $\mathrm{HCO}_{3}{ }^{-}$or $\mathrm{CO}_{2}$ being the electrochemically active species. Therefore, all literature concerning electrochemical conversion of $\mathrm{CO}_{2}$ to formate in $\mathrm{KHCO}_{3}$ electrolyte is relevant to this thesis and this thesis itself concerns electroreduction of $\mathrm{CO}_{2}$. 


\section{References}

1. Back, S., Kim, J.-H., Kim, Y.-T. \& Jung, Y. On the mechanism of high product selectivity for $\mathrm{HCOOH}$ using $\mathrm{Pb}$ in CO2 electroreduction. Phys. Chem. Chem. Phys. 18, 9652-9657 (2016).

2. Wu, J., Risalvato, F. G., Ke, F.-S., Pellechia, P. J. \& Zhou, X.-D. Electrochemical Reduction of Carbon Dioxide I. Effects of the Electrolyte on the Selectivity and Activity with $\mathrm{Sn}$ Electrode. J. Electrochem. Soc. 159, F353-F359 (2012).

3. Scialdone, O. et al. Electrochemical reduction of carbon dioxide to formic acid at a tin cathode in divided and undivided cells: effect of carbon dioxide pressure and other operating parameters. Electrochim. Acta 199, 332-341 (2016).

4. Irtem, E. et al. Low-energy formate production from $\mathrm{CO} 2$ electroreduction using electrodeposited tin on GDE. J. Ma 4, 13582-13588 (2016).

5. Bevilacqua, M., Filippi, J., Miller, H. A. \& Vizza, F. Recent Technological Progress in CO2 Electroreduction to Fuels and Energy Carriers in Aqueous Environments. Energy Technol. 3, 197-210 (2015).

6. Lu, X., Leung, D. Y. C., Wang, H., Leung, M. K. H. \& Xuan, J. Electrochemical Reduction of Carbon Dioxide to Formic Acid. ChemElectroChem 1, 836-849 (2014).

7. Zhang, W. et al. Progress and Perspective of Electrocatalytic CO2 Reduction for Renewable Carbonaceous Fuels and Chemicals. Adv. Sci. 5, 1-24 (2018).

8. Wuttig, A., Yoon, Y., Ryu, J. \& Surendranath, Y. Bicarbonate Is Not a General Acid in AuCatalyzed CO2 Electroreduction. J. Am. Chem. Soc. 139, 17109-17113 (2017).

9. Goodridge, F. \& Scott, K. Electrochemical process engineering: a guide to the design of electrolytic plant. (Springer Science \& Business Media, 1995).

10. Zhu, S., Jiang, B., Cai, W. Bin \& Shao, M. Direct Observation on Reaction Intermediates and the Role of Bicarbonate Anions in CO2 Electrochemical Reduction Reaction on Cu Surfaces. J. Am. Chem. Soc. 139, 15664-15667 (2017).

11. Dunwell, M. et al. The Central Role of Bicarbonate in the Electrochemical Reduction of Carbon Dioxide on Gold. J. Am. Chem. Soc. 139, 3774-3783 (2017).

12. Pander, J. E., Baruch, M. F. \& Bocarsly, A. B. Probing the Mechanism of Aqueous CO2 Reduction on Post-Transition-Metal Electrodes using ATR-IR Spectroelectrochemistry. ACS Catal. 6, 7824-7833 (2016).

13. Innocent, B. et al. Electro-reduction of carbon dioxide to formate on lead electrode in aqueous medium. J. Appl. Electrochem. 39, 227-232 (2009).

14. White, J. L., Herb, J. T., Kaczur, J. J., Majsztrik, P. W. \& Bocarsly, A. B. Photons to formate: Efficient electrochemical solar energy conversion via reduction of carbon dioxide. J. CO2 Util. 7, 1-5 (2014).

15. Li, H. \& Oloman, C. The electro-reduction of carbon dioxide in a continuous reactor. J. Appl. Electrochem. 35, 955-965 (2005).

16. Li, H. \& Oloman, C. Development of a continuous reactor for the electro-reduction of carbon dioxideto formate - Part 1: Process variables. J. Appl. Electrochem. 36, 1105-1115 (2006).

17. Li, H. \& Oloman, C. Development of a continuous reactor for the electro-reduction of carbon dioxide to formate - Part 2: Scale-up. J. Appl. Electrochem. 37, 1107-1117 (2007).

18. Oloman, C. \& Li, H. Electrochemical processing of carbon dioxide. ChemSusChem 1, 385391 (2008).

19. Kopljar, D., Inan, A., Vindayer, P., Wagner, N. \& Klemm, E. Electrochemical reduction of $\mathrm{CO} 2$ to formate at high current density using gas diffusion electrodes. J. Appl. Electrochem. 44, 1107-1116 (2014).

20. Agarwal, A. S., Zhai, Y., Hill, D. \& Sridhar, N. The electrochemical reduction of carbon dioxide to formate/formic acid: Engineering and economic feasibility. ChemSusChem 4, 1301-1310 (2011).

21. Larrazábal, G. O., Martín, A. J. \& Pérez-Ramírez, J. Building Blocks for High Performance in Electrocatalytic CO2 Reduction: Materials, Optimization Strategies, and Device Engineering. 
J. Phys. Chem. Lett. 8, 3933-3944 (2017).

22. Wu, J., Huang, Y., Ye, W. \& Li, Y. CO2 Reduction: From the Electrochemical to Photochemical Approach. Adv. Sci. 4, 1-29 (2017).

23. Rumble, J. CRC handbook of chemistry and physics: A ready-reference book of chemical and physical data. (CRC Press/Taylor \& Francis, Boca Raton, FL, 2018).

24. Salazar-villalpando, M. D. Effect of Electrolyte on the Electrochemical Reduction of CO2. ECS Trans. 33, 77-88 (2011).

25. Tanaka, Y. Fundamental Properties of Ion Exchange Membranes. in Ion Exchange Membranes 29-65 (2015). doi:10.1016/B978-0-444-63319-4.00002-X

26. Wu, J. et al. Electrochemical Reduction of Carbon Dioxide: II. Design, Assembly, and Performance of Low Temperature Full Electrochemical Cells. J. Electrochem. Soc. 160, F953F957 (2013).

27. Chemours. Product Bulletin P-12 Nafion N115, N117, N110. (2016).

28. Blom, M. J. W., van Swaaij, W. P. M., Mul, G. \& Kersten, S. R. A. Overall mass balance evaluation of electrochemical reactors: The case of $\mathrm{CO} 2$ reduction. Electrochim. Acta 333, 135460 (2020).

29. Ayers, K. E. et al. Research Advances Towards Low Cost, High Efficiency PEM Electrolysis. Electrochem. Soc. 33, 3-15 (2010).

30. Rashid, M. M., Mesfer, M. K. Al, Naseem, H. \& Danish, M. Hydrogen Production by Water Electrolysis: A Review of Alkaline Water Electrolysis, PEM Water Electrolysis and High Temperature Water Electrolysis. Int. J. Eng. Adv. Technol. 2249-8958 (2015).

31. Yang, Y., Power, A. \& Hart, D. PEM \& Alkaline Electrolyzers Bottom-up Manufacturing Cost Analysis. (2014).

32. Tahir, M. et al. Electrocatalytic oxygen evolution reaction for energy conversion and storage: A comprehensive review. Nano Energy 37, 136-157 (2017).

33. Wu, Z., Lu, X. F., Zang, S., Wen, X. \& Lou, D. Non-Noble-Metal-Based Electrocatalysts toward the Oxygen Evolution Reaction. 1910274, 1-20 (2020).

34. Zhou, X. et al. Solar-Driven Reduction of $1 \mathrm{~atm}$ of CO2 to Formate at 10\% Energy-Conversion Efficiency by Use of a TiO2-Protected III-V Tandem Photoanode in Conjunction with a Bipolar Membrane and a Pd/C Cathode. ACS Energy Lett. 1, 764-770 (2016).

35. Vermaas, D. A., Wiegman, S., Nagaki, T. \& Smith, W. A. Ion transport mechanisms in bipolar membranes for (photo)electrochemical water splitting. Sustain. Energy Fuels 2006-2015 (2018). doi:10.1039/C8SE00118A

36. Li, Y. C. et al. Electrolysis of CO2to Syngas in Bipolar Membrane-Based Electrochemical Cells. ACS Energy Lett. 1, 1149-1153 (2016).

37. Yang, H., Kaczur, J. J., Sajjad, S. D. \& Masel, R. I. Electrochemical conversion of CO2 to formic acid utilizing Sustainion ${ }^{\mathrm{TM}}$ membranes. J. CO2 Util. 20, 208-217 (2017).

38. Aeshala, L. M., Rahman, S. U. \& Verma, A. Effect of solid polymer electrolyte on electrochemical reduction of CO2. Sep. Purif. Technol. 94, 131-137 (2012).

39. Du, D., Lan, R., Humphreys, J. \& Tao, S. Progress in inorganic cathode catalysts for electrochemical conversion of carbon dioxide into formate or formic acid. J. Appl. Electrochem. 47, 661-678 (2017). 


\section{Appendix}

\section{A2.1 Algebraic equations for shortcut method}

$\mathrm{R}=$ Electrochemical productivity in coulomb per liter of catholyte.

$$
\begin{aligned}
& {\left[\mathrm{HCO}_{3}^{-}\right]=\left\{\begin{array}{r}
{\left[\mathrm{HCO}_{3}^{-}\right]_{0}-\frac{R}{n F}, \frac{R}{n F}<\left[\mathrm{HCO}_{3}^{-}\right]_{0}} \\
0, \frac{R}{n F} \geq\left[\mathrm{HCO}_{3}^{-}\right]_{0}
\end{array}\right.} \\
& {\left[\mathrm{HCOO}^{-}\right]=\left\{\begin{array}{r}
\frac{R}{n F}, \frac{R}{n F}<\left[\mathrm{HCO}_{3}^{-}\right]_{0} \\
{\left[\mathrm{HCO}_{3}^{-}\right]_{0}, \frac{R}{n F} \geq\left[\mathrm{HCO}_{3}^{-}\right]_{0}}
\end{array}\right.} \\
& {[\mathrm{HCOOH}]=\left\{\begin{array}{r}
0, \frac{R}{n F}<\left[\mathrm{HCO}_{3}^{-}\right]_{0} \\
\frac{R}{n F}-\left[\mathrm{HCO}_{3}^{-}\right]_{0}, \frac{R}{n F} \geq\left[\mathrm{HCO}_{3}^{-}\right]_{0}
\end{array}\right.}
\end{aligned}
$$

\section{A2.2 Extended catholyte acid-base equilibrium model}

Extended acid-base equilibrium calculations are performed using the equilibrium equations shown in Table A2.1 and equilibrium constants shown in Table A2.2. Details regarding the method are presented below.

Table A2.1: Catholyte equilibrium equations for electrochemical conversion reactor in main article

$$
\begin{aligned}
& {\left[\mathrm{CO}_{2}\right]=\mathrm{H} \cdot \mathrm{p}_{\mathrm{CO}_{2}}} \\
& \frac{\left[\mathrm{HCO}_{3}^{-}\right]}{\left[\mathrm{CO}_{2}\right]\left[\mathrm{OH}^{-}\right]}=K_{1} \\
& \frac{\left[\mathrm{CO}_{3}^{2-}\right]}{\left[\mathrm{HCO}_{3}^{-}\right]\left[\mathrm{OH}^{-}\right]}=K_{2} \\
& {\left[\mathrm{OH}^{-}\right]\left[\mathrm{H}^{+}\right]=K_{w}} \\
& \frac{\left[\mathrm{H}^{+}\right]\left[\mathrm{HCOO}^{-}\right]}{[\mathrm{HCOOH}]}=K_{3} \\
& {\left[\mathrm{~K}^{+}\right]+\left[\mathrm{H}^{+}\right]=2\left[\mathrm{CO}_{3}^{2-}\right]+\left[\mathrm{HCO}_{3}^{-}\right]+\left[\mathrm{HCOO}^{-}\right]+\left[\mathrm{OH}^{-}\right]} \\
& {\left[\mathrm{HCOO}^{-}\right]+[\mathrm{HCOOH}]=c_{f}}
\end{aligned}
$$

Step 1: substitute equation A2.10 into equation A2.8a and rewrite. 


$$
\frac{\left[\mathrm{HCOO}^{-}\right]}{c_{f}-\left[\mathrm{HCOO}^{-}\right]}=\frac{K_{3}}{\left[\mathrm{H}^{+}\right]}
$$

Step 2: Rewrite

$$
\left[\mathrm{HCOO}^{-}\right]=\frac{K_{3}}{\left[\mathrm{H}^{+}\right]} \cdot\left(c_{f}-\left[\mathrm{HCOO}^{-}\right]\right)=\frac{K_{3} \cdot c_{f}}{\left[\mathrm{H}^{+}\right]}-\frac{K_{3}}{\left[\mathrm{H}^{+}\right]} \cdot\left[\mathrm{HCOO}^{-}\right]
$$

Step 3: rewrite all [HCOO$\left.{ }^{-}\right]$to one side

$$
\left(1+\frac{K_{3}}{\left[H^{+}\right]}\right) \cdot\left[\mathrm{HCOO}^{-}\right]=\frac{K_{3} \cdot c_{f}}{\left[H^{+}\right]}
$$

Step 4: Result.

$$
\left[\mathrm{HCOO}^{-}\right]=\frac{K_{3} \cdot c_{f}}{\left[H^{+}\right] \cdot\left(1+\frac{K_{3}}{\left[H^{+}\right]}\right)}=\frac{K_{3} \cdot c_{f}}{\left[H^{+}+k_{3}\right]}
$$

Table A2.2: Values of equilibrium constants

\begin{tabular}{ll}
\hline $\mathrm{H}$ & $0.034 \mathrm{~mol} /(\mathrm{L} \cdot \mathrm{bar})$ \\
$\mathrm{K}_{1}$ & $4.44 \cdot 10^{7} \mathrm{~L} / \mathrm{mol}$ \\
$\mathrm{K}_{2}$ & $4.66 \cdot 10^{3} \mathrm{~L} / \mathrm{mol}$ \\
$\mathrm{K}_{3}$ & $1.78 \cdot 10^{-4} \mathrm{~mol} / \mathrm{L}$ \\
$\mathrm{K}_{\mathrm{w}}$ & $1 \cdot 10^{-14} \mathrm{~mol}^{2} / \mathrm{L}^{2}$ \\
$\mathrm{c}_{\mathrm{f}}$ & Constant, equal to productivity \\
\hline
\end{tabular}
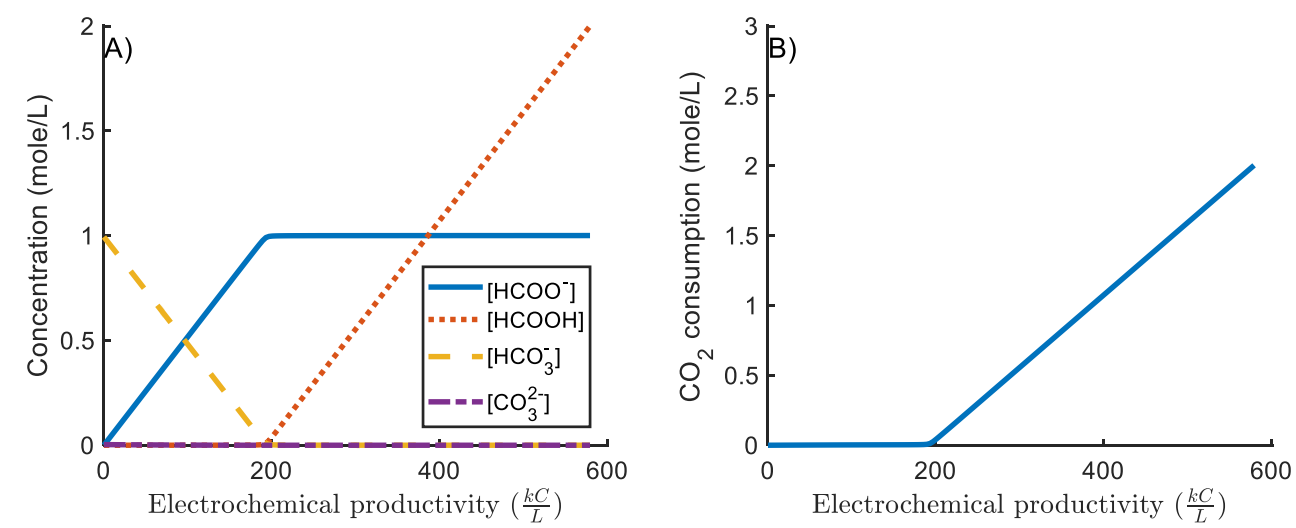

Figure A2.1: A) Concentration of selected species in catholyte and B) $\mathrm{CO2}$ consumption as function productivity, both using extended acid-base equilibrium model) [Cathode | CO2 + KHCO3 | CEM | H2SO4 | Anode]

To calculate the equilibrium composition at various values for the productivity, $\mathrm{c}_{\mathrm{f}}$ was set equal to the productivity (mole/L). Since the transport of protons cancels out the consumption 
of protons, the net combined Cathodic reaction + transport flux equals 0 . Therefore all variables are known and acid-base equilibria are calculated at $298 \mathrm{~K}$ and 1 bar. The results are shown in Figure A2.1 and closely resemble that of Figure 2.3 and 2.4A in the main text.

\section{A2.3 CSTR analytic equations}

\begin{tabular}{lll}
\multicolumn{2}{l}{ Extra nomenclature appendix } & \\
\hline Variable & Description & $\mathrm{unit}$ \\
\hline$b_{i}^{j}$ & Molal concentration of species i in electrolyte j & $\mathrm{mole} / \mathrm{kg}$ \\
$b_{i, \text { in }}^{j}$ & Molal concentration of species i in inflow to electrolyte j & $\mathrm{mole} / \mathrm{kg}$ \\
$M_{i}$ & Molecular weight of species i & $\mathrm{kg} / \mathrm{mole}$ \\
$\rho^{j}$ & Density of electrolyte j & $\mathrm{kg} / \mathrm{L}$ \\
$\phi_{m, \text { in }}^{j}$ & Mass flow into electrolyte j & $\mathrm{kg} / \mathrm{s}$ \\
$\phi_{m, \text { out }}^{j}$ & Mass flow out of electrolyte j & $\mathrm{kg} / \mathrm{s}$ \\
\hline
\end{tabular}

The steady state mass balance over a continuous ideally stirred tank rea ctor (CSTR) is considered. The balance is constructed per liquid phase electrolyte $\mathrm{j}$ in mole/s, based on mass flow and molality. For a steady state balance, the sum of inflow, outflow, transports and reactions should be zero (equation A2.14). Transports include transport through the membrane and transport between the gas and liquid phase. Reactions are the sum of electrode reactions occurring at the electrode surface and bulk reactions, e.g. acid-base reactions or homogeneous catalytic reactions. Reaction are defined based on stoichiometry and the Faradaic current through the reactor.

The steady state mass balance is shown in algebraic form for the catholyte as equations A2.15 and the anolyte as equation A2.16. The transport number for transfer of species i across the membrane is defined in equation A2.17. And the relation between current and ion transfer across the membrane as equation A2.18. From here on, only the catholyte balance shall be considered. Mass conservation dictates that the outgoing mass equals the ingoing mass plus the mass added by transports (equation A2.19). Substitution of A2.19 into A2.15 yields equation A2.20, which rearranges to equation A2.21 and is the formal mass balance over the catholyte.

Feed inflow - Product outflow + Transport + reaction $=0$

$\phi_{m, \text { in }}^{c} b_{i, \text { in }}^{c}-\phi_{m, \text { out }}^{c} b_{i}^{c}+f_{i}^{c}+\frac{I}{z_{i}} \overline{t_{i}}+v_{i}^{c} \frac{I}{n F}=0$

$\phi_{m, \text { in }}^{a} b_{i, \text { in }}^{a}-\phi_{m, \text { out }}^{a} b_{i}^{a}+f_{i}^{a}-\frac{I}{F z_{i}} \bar{t}_{i}+v_{i}^{a} \frac{I}{n F}=0$

$\overline{t_{i}}=\frac{z_{i} J_{i}}{\sum_{i} z_{i} J_{i}}$

$I=F \sum_{i} z_{i} J_{i}$ 


$$
\begin{aligned}
& \phi_{m, \text { out }}^{a}=\phi_{m, \text { in }}^{a}+\sum_{i}\left(f_{i}^{j} M_{i}+\frac{I}{F z_{i}} \overline{t_{i}} M_{i}\right) \\
& \left(\phi_{m, \text { out }}^{a}-\sum_{i}\left(f_{i}^{c} M_{i}+\frac{I}{F z_{i}} \overline{t_{i}} M_{i}\right)\right) b_{i, \text { in }}^{c}-\phi_{m, \text { out }}^{c} b_{i}^{c}+f_{i}^{c}+\frac{I}{F z_{i}} \overline{t_{i}}+v_{i}^{c} \frac{I}{n F}=0 \\
& \left(1-\frac{\sum_{i}\left(f_{i}^{c} M_{i}+\frac{I}{F z_{i}} \overline{t_{i}} M_{i}\right)}{\phi_{m, \text { out }}^{c}}\right) b_{i, \text { in }}^{c}-b_{i}^{c}+\frac{f_{i}^{c}}{\phi_{m, \text { out }}^{j}}+\frac{\overline{t_{i}}}{F z_{i}} \frac{I}{\phi_{m, \text { out }}^{c}}+\frac{v_{i}^{c}}{n F} \frac{I}{\phi_{m, \text { out }}^{c}}=0
\end{aligned}
$$

In specific cases, this mass balance may be simplified. When the molar mass of species transported through the membrane is low (e.g. protons) and transport between gas and liquid phase is negligible, the mass inflow and outflow are approximately equal, which simplifies A2.21 to A2.22. Moreover, when reactions and transport have a negligible effect on electrolyte density, A2.22 may be written in terms of molar concentrations (A2.23). The electrochemical productivity is defined in equation A2.24. When this is substituted into equation A2.23, it yields the final simplified balance, equation A2.25. The results from equation A2.25 are identical to those presented as Figure 2.3 in the main article, when the same reactions and transports are considered. This shows that mixing does not affect the results, as long as electrode reactions and transport are not a function of concentration.

$b_{i, \text { in }}^{c}-b_{i}^{c}+\frac{f_{i}^{c}}{\phi_{m, \text { out }}^{j}}+\overline{\frac{t_{i}}{F z_{i}}} \frac{I}{\phi_{m, \text { out }}^{c}}+\frac{v_{i}^{c}}{n F} \frac{I}{\phi_{m, \text { out }}^{c}}=0$

Assume constant density

$$
\begin{aligned}
& c_{i, i n}^{c}-c_{i}^{c}+\frac{f_{i}^{c}}{\phi_{v}^{c}}+\frac{\overline{t_{i}}}{F z_{i}} \frac{I}{\phi_{v}^{c}}+\frac{v_{i}^{c}}{n F} \frac{I}{\phi_{v}^{c}}=0 \\
& \frac{I}{\phi_{v}^{j}}=R_{\text {flow }}^{j} \\
& c_{i, \text { in }}^{c}-c_{i}^{c}+\left(f_{i}^{c} \frac{n F}{I}+\bar{t}_{i} \frac{n}{z_{i}}+v_{i}^{c}\right) \frac{R_{\text {flow }}^{c}}{n F}=0
\end{aligned}
$$






\section{Chapter 3}

\section{Pulsed reduction of $\mathrm{CO}_{2}$ on $\mathrm{Pb}$ electrodes}

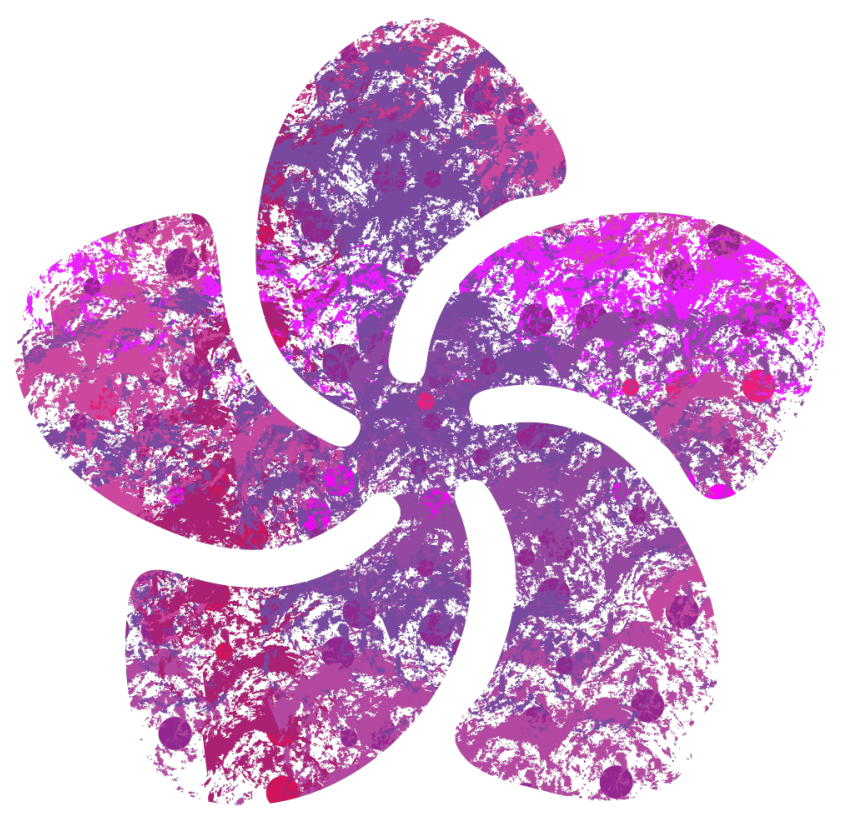

'You must be ready to give up even the most attractive ideas when experiments show them to be wrong'

$$
\text { - Alessandro Volta - }
$$




\begin{abstract}
Lead cathodes show decreasing Faradaic Efficiency (FE) in electrochemical conversion of $\mathrm{CO} 2$ to formate, favoring hydrogen within minutes of operation in bicarbonate electrolyte at -1 to $-1.3 \mathrm{~V}$ vs RHE. Periodic anodic polarization (pulsed electrochemistry) is used to obtain a high time-averaged FE towards formate. An anodic polarization time of $0.1-1 \mathrm{~s}$, in combination with cathodic polarization of $0.1 \mathrm{~s}$, appears optimal to maintain a $\mathrm{Pb}$-surface providing a continuously high averaged formate FE of $\sim 50 \%$. Raman spectroscopy shows that $\mathrm{PbCO} 3$ is initially present on the surface of the cathode, inducing a high FE, while this is reductively converted to metallic $\mathrm{Pb}$ at -1 to- $1.3 \mathrm{~V}$ vs RHE. This species is easily regenerated by anodic polarization at $0.05 \mathrm{~V}$ vs RHE, thus restoring activity.
\end{abstract}

This chapter has been published as :

Blom, M. J. W., Smulders, V., van Swaaij, W. P. M., Kersten, S. R. A., \& Mul, G. Pulsed electrochemical synthesis of formate using $\mathrm{Pb}$ electrodes. Applied Catalysis $\mathrm{B}$ : Environmental 268, (2020) 118420. 


\subsection{Introduction}

Most heterogeneous electrocatalysts that can reduce $\mathrm{CO}_{2}$ to formate are based on $\mathrm{Pb}, \mathrm{Pd}, \mathrm{Sn}$, $\mathrm{In}, \mathrm{Hg}, \mathrm{Zn}$ and $\mathrm{Bi}^{1-4}$ Of those metals, only $\mathrm{Pb}$ and $\mathrm{Sn}$ based electrocatalysts are oftentimes reported to have high selectivity for reduction of $\mathrm{CO} 2$ to formate (3.1), whereas other metals are more selective towards $\mathrm{H} 2, \mathrm{CO}$ or other $\mathrm{CO} 2$ reduction products. ${ }^{1-4}$ From a technology readiness viewpoint, processes for the production of $\mathrm{Pb}$ electrodes have long existed for manufacturing lead-acid batteries. ${ }^{5}$ Therefore, this chapter focusses on $\mathrm{Pb}$ electrodes as a potential easy-to-implement $\mathrm{CO}_{2}$ reduction catalyst.

$$
\mathrm{CO}_{2}+\mathrm{HA}^{\mathrm{z}+1}+2 e^{-} \rightleftarrows \mathrm{HCOO}^{-}+A^{z}
$$

One of the major challenges identified for the scale-up of $\mathrm{CO}_{2}$ electro-reduction is activity degradation of non-noble metal catalysts. ${ }^{6} \mathrm{~Pb}$ cathodes have been reported to show an initial FE as high as $97 \% .^{7}$ However, the maximum Faraday efficiency (FE) and corresponding partial current density to formate $\left(i_{\text {formate }}\right.$ ) for $\mathrm{Pb}$ cathodes is largely dependent on the nature of the electrolyte used, the applied electrochemical reactor, but also reaction time after which product concentrations were determined ${ }^{1}$, as illustrated in Table 3.1. Therefore, understanding and increasing the temporal stability of $\mathrm{Pb}$ electrocatalysts is needed.

Table 3.1: Selection of literature results on maximum reported FE, and corresponding cell parameters for electrochemical reduction of $\mathrm{CO} 2$ on $\mathrm{Pb}$ cathodes at $18^{\circ} \mathrm{C}-25^{\circ} \mathrm{C}$ and 1 bar $\mathrm{CO2}$ pressure.

\begin{tabular}{lllllllc}
\hline $\begin{array}{l}\text { Potential } \\
\mathrm{V}\end{array}$ & & Electrolyte & $\mathrm{i}_{\text {formate }}$ & $\mathrm{FE}$ & Reactor & Time & Ref \\
$\mathrm{Ag} / \mathrm{AgCl}$ & $\mathrm{RHE}$ & & $\mathrm{mA} / \mathrm{cm}^{2}$ & $\%$ & & min & \\
\hline-1.46 & -0.81 & $0.5 \mathrm{M} \mathrm{KHCO}_{3}$ & -0.71 & 90 & Fixed bed & 30 & 8 \\
-1.46 & -0.81 & $0.5 \mathrm{M} \mathrm{KHCO}_{3}$ & -0.24 & 30 & Fixed bed & 120 & 8 \\
-1.56 & -0.91 & $0.5 \mathrm{M} \mathrm{NaHCO}_{3}$ & & 62 & Filter-press & $120-240$ & 9 \\
-1.61 & -0.96 & $0.5 \mathrm{M} \mathrm{NaHCO}_{3}$ & -0.06 & 55 & H-cell & & 10 \\
-1.84 & -1.22 & $0.1 \mathrm{M} \mathrm{KHCO}_{3}$ & -4.87 & 97 & H-cell & & 7 \\
-2.00 & & & -30 & 65 & zero gap & & 11 \\
-2.16 & -1.56 & $0.05 \mathrm{M} \mathrm{KHCO}_{3}$ & & 10 & H-cell & & 12 \\
\hline
\end{tabular}

\footnotetext{
${ }^{\dagger}$ Where $\mathrm{A}$ can be $\mathrm{H}_{2} \mathrm{O}, \mathrm{OH}^{-}, \mathrm{HCO}_{3}{ }^{-}, \mathrm{CO}_{3}{ }^{2-}$ or $\mathrm{HCOO}^{-}$and $\mathrm{z}$ denotes charge

* The reversible half-reaction potential for reduction of $\mathrm{CO}_{2}$ to formate under $1 \mathrm{~atm} . \mathrm{CO}_{2}$ in $1 \mathrm{M} \mathrm{KHCO}$ is $-0.72 \mathrm{~V}$ vs $\mathrm{Ag} / \mathrm{AgCl}$. The $\mathrm{pH}$ for calculating potential versus RHE was estimated based on $\mathrm{p}_{\mathrm{CO} 2}$, the electrolyte and carbonaceous equilibrium description (Appendix Chapter 2).
} 
In a recent publication by Lee and Kanan, the preparation method of $\mathrm{Pb}$ cathodes is shown to have a drastic effect on electrode activity. ${ }^{10}$ They showed that lead cathodes made by reduction of $\mathrm{PbO}_{2}$ provide an initial $\mathrm{FE}$ to formate of $95 \%$ in $\mathrm{N}_{2}$ saturated $1 \mathrm{M} \mathrm{KHCO}_{3}$, whereas regular $\mathrm{Pb}$ foil only showed a $\mathrm{FE}$ of $5 \%$ under similar conditions. They hypothesize that the difference is due to a thin lead oxide (hydroxide) layer, passivating the electrode for $\mathrm{H}_{2}$ evolution, but allowing reactivity for formate production. $\mathrm{Pb}^{0}$ sites thus likely induce hydrogen evolution. ${ }^{10}$ Lee and Kanan show a decline in $i_{\text {formate }}$ over 4 hours experimental time, possibly explained by the metastable nature of the active $\mathrm{Pb}$ (oxide) species. ${ }^{10}$ In situ (re)generation of the active species should prevent the $\mathrm{i}_{\text {formate }}$ decline.

Changes in oxidation state of as-prepared electrodes in electrochemical reduction of $\mathrm{CO}_{2}$ have also been previously reported for $\mathrm{Cu}$-oxide-derived electrodes, which is thought by some researchers to induce electrode deactivation ${ }^{13,14}$. Interestingly, periodic anodic polarization of $\mathrm{Cu}$ diminished such deactivation, extending the lifetime of copper electrodes for high Faraday Efficiency. ${ }^{13,14}$ The effect of periodic anodic polarization on the performance of $\mathrm{Pb}$-electrodes was not previously studied and is the subject of this chapter.

\subsection{Materials and methods}

All electrochemical experiments were conducted in a three-electrode, divided electrochemical cell at ambient temperature. Both the anolyte and catholyte were $1 \mathrm{M}$ $\mathrm{KHCO}_{3}(99.7 \%$, Sigma Aldrich) in Milli-Q water. Prior to experiments, the electrolyte was sparged with 0.3 bar partial $\mathrm{CO}_{2}$ pressure in Ar for 30 minutes. During experiments, $0.3 \mathrm{bar}$ partial $\mathrm{CO}_{2}$ pressure in $\mathrm{Ar}$ was supplied as a gas cap above the solution at atmospheric pressure, resulting in a constant $\mathrm{pH}$ of the solution of 8.4. This mimics a situation where all $\mathrm{CO}_{2}$ is supplied from bicarbonate via the carbonaceous equilibrium reactions, as the equilibrium pressure of $\mathrm{CO}_{2}$ in contact with $\mathrm{KHCO}_{3}$ is 0.3 bar at $\mathrm{pH} 8.35$. The constant $\mathrm{pH}$ before and after the experiment indicates that $\mathrm{CO}_{2}$ saturation was sufficient. The catholyte and anolyte volumes were $30 \mathrm{ml}$ and approximately $3 \mathrm{ml}$ respectively. The catholyte was stirred continuously. The short time experiments in Figure 3.2 are conducted in a different but similar cell that has higher electrode area to volume ratio. That is needed to build up a high enough formate concentration for accurate detection within the short experimental time. The cell and method are described in appendix A3.1.

A fresh $\mathrm{Pb}$ foil working electrode of $0.81 \mathrm{~cm}^{2}$ (99.8\%, Alfa Aesar), was consecutively rinsed in $70 \% \mathrm{HNO}_{3}$ (Sigma Aldrich), Milli-Q water and wiped with paper, prior to each experiment. The counter electrode was a Pt mesh (Alfa Aesar) and the membrane, that separates the catholyte and anolyte, was an AMI-7001S anion exchange membrane (Membranes International Inc.). The authors are aware of recent concerns regarding $\mathrm{Pt}$ dissolution from the anode. ${ }^{15}$ Additional test with a graphite counter electrode showed no significant effect of Pt dissolution. $\mathrm{A} \mathrm{Ag} / \mathrm{AgCl}$ reference electrode (3M NaCl, ProSense) was used and potentials are reported relative to the reversible hydrogen electrode (RHE). 
Electrochemical experiments were controlled using a Versastat 3 potentioSTAT (Princeton Applied Research).

Electrochemical reduction of $\mathrm{CO}_{2}$ was performed for 16 hours, to obtain sufficiently high formic acid concentration in solution to be detected by HPLC after the experiment. The pulsed experiments (periodic anodic polarization) were conducted using repeated square wave potential pulses, as defined in Figure 3.1. Per wave, the anodic and cathodic polarization time are defined as $t_{\text {anodic }}$ and $t_{\text {cathodic }}$ respectively. The period of the wave is denoted as $\lambda$ and is reported in seconds. The total number of waves (cycles) per experiment (N) is equal to $\frac{16 \text { hours } 3600}{\lambda}$.

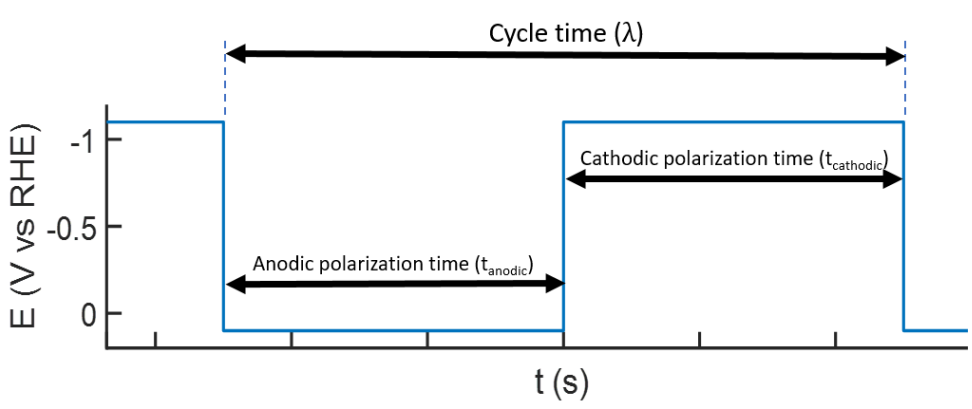

Figure 3.1: Definition of applied potential waveform in pulsed experiments; these were repeated to a total electrochemical experiment of 16 hours.

During the pulsed experiments, especially at high frequency, (reversible) transient processes occurring at the switching of potential can attribute significantly to the total current. Therefore, the FE is defined based on the net charge flow $Q_{\text {net }}$ (the sum of oxidative and reductive charge flow), equation 3.2. In equation 3.2, $\mathrm{n}$ denotes the molar amount of formate formed (HPLC with RID, Agilent Technologies. Hi-Plex $\mathrm{H}$ column at $65^{\circ} \mathrm{C}$, using $5 \mathrm{mM}$ $\mathrm{H}_{2} \mathrm{SO}_{4}$ eluent at $0.6 \mathrm{~mL} / \mathrm{min}$.), $\mathrm{S}$ the exposed working electrode area and $\mathrm{F}$ the Faraday constant. Formate can only be formed electrochemically during cathodic polarization, hence $\mathrm{i}_{\text {formate }}$ is calculated based on the total cathodic polarization time, via equation 3.3.

$F E=\frac{-2 \cdot n \cdot F}{Q_{n e t}} \cdot 100 \%$

$i_{\text {formate }}=\frac{-2 \cdot n \cdot F}{S \cdot N \cdot t_{\text {cathodic }}}$

To determine proper operation of the membrane, in several experiments a small initial amount of formate was added to the cathodic electrolyte ( $1 \mathrm{mM} \mathrm{KHCOO,} \mathrm{Potassium} \mathrm{Formate,}$ Sigma Aldrich). If formate would transfer across the membrane, this would then be evident as loss of formate. Fortunately, 'leaking' membranes have not been observed in the present study. Error bars presented show the measurement error introduced by the uncertainty in HPLC analysis, electrolyte volume (evaporation) and charge flow, which is further described in appendix A3.2. 
Raman spectroscopy was conducted in a homemade electrochemical flow-cell that allowed a Raman probe to be inserted. The Raman spectroscope was an Avantes Sensline AvaSpecHSC-TEC using a laser wavelength of $785 \mathrm{~nm}$ at a laser power of $1 \mathrm{~A}$. A Pb working electrode was used in combination with a Pt counter electrode and Pt wire as pseudo-reference electrode. Prior to experiments, the $\mathrm{Pt}$ wire was calibrated versus the $\mathrm{Ag} / \mathrm{AgCl}$ reference electrode. The electrolyte used was $0.1 \mathrm{M} \mathrm{KHCO} 3$, as in $1 \mathrm{M} \mathrm{KHCO}_{3}$ the $\mathrm{HCO}_{3}^{-}$(aq) peak overlapped with some of the other features.

\subsection{Results and discussion}
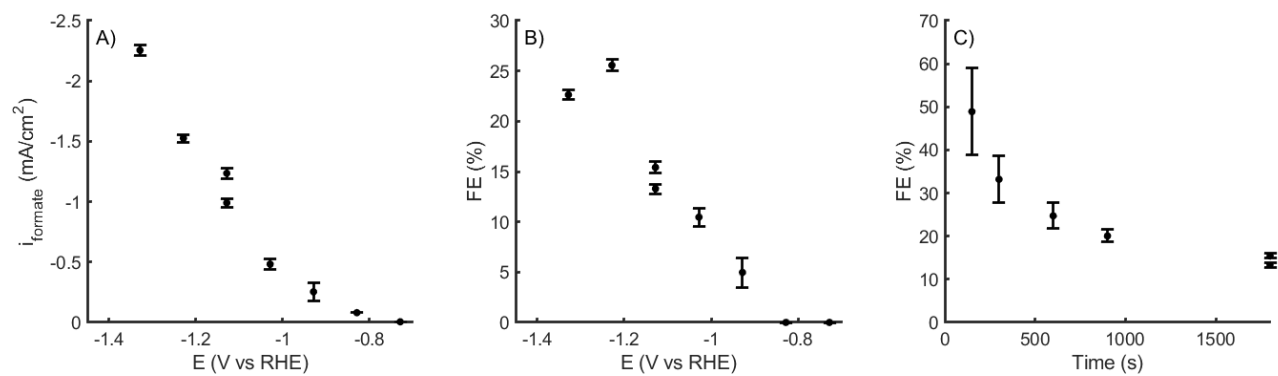

Figure 3.2: The performance of a $\mathrm{Pb}$ cathode in $\mathrm{CO}_{2}$ reduction in $1 \mathrm{M} \mathrm{KHCO}_{3}$ catholyte. A) Partial current density to formate (30 minutes experimental time). B) Faraday efficiency to formate (30 minutes experimental time). C) Faraday efficiency to formate at $-1.1 \mathrm{~V}$ vs RHE

First, $\mathrm{Pb}$ electrodes were studied under continuous cathodic polarization at various potentials, to compare performance versus literature benchmarks. The formate specific current density (Figure 3.2A) increases monotonically with increasingly negative potential and FE shows a maximum of $26 \%$ at $-1.2 \mathrm{~V}$ vs RHE (Figure 3.2B). Those results do not stand out from data obtained by others, as reported in Table 3.1. Then, at constant potential, the runtime of an experiment was varied (Figure 3.2C), which clearly shows decreasing activity over time. The FE to formate decreases from $50 \%$ after $150 \mathrm{~s}$ to $14 \%$ after $1800 \mathrm{~s}$. This trend is in agreement with the results of Köleli et al. who observed a decline in average activity from $-0.71 \mathrm{~mA} / \mathrm{cm}^{2}$ and $90 \%$ FE to $-0.24 \mathrm{~mA} / \mathrm{cm}^{2}$ and $30 \%$ FE, respectively, when experimental times of $0.5 \mathrm{~h}$ and $2 \mathrm{~h}$ were compared. ${ }^{8}$ The 16 hour experimental time employed in the remainder of this study results in less than $3 \%$ Faraday efficiency for all potentials measured (-0.8 to $-1.3 \mathrm{~V} v \mathrm{~s}$ RHE) in continuous cathodic polarization experiments (Figure A3.1). Evidently, under operating conditions, $\mathrm{Pb}$ cathodes lose a significant part of their activity within 30 minutes.

To survey the effects of periodic anodic polarization, symmetric square waves were applied to the cathode, over a wide frequency range. The experiments were performed in duplo, showing good reproducibility. Figure 3.3 shows $i_{\text {formate }}$ and FE for cycles of cathodic and anodic potentials of $-1.1 \mathrm{~V}$ and $+0.05 \mathrm{~V}$ (slightly anodic of the open circuit voltage) $v s \mathrm{RHE}$, respectively. For very high frequency waves $(\lambda=0.002 \mathrm{~s})$, there is no significant positive effect, and formate production is low. It is reasonable to assume that non-faradaic startup 
processes e.g. double layer formation, dominate in the high frequency regime. Formate production could be inhibited by fast re-oxidation of intermediates. At lower frequency, there is a significant increase in $\mathrm{i}_{\text {formate }}$ and $\mathrm{FE}$ using periodic anodic polarization, as compared to chrono-amperometry measurements at constant potential. A time-averaged FE of $\sim 50 \%$ was obtained with $\lambda=0.02 \mathrm{~s}$ and $0.2 \mathrm{~s}$, while increasing $\lambda$ to $10 \mathrm{~s}$, results in a lower FE of approximately $30 \%$. Periodic anodic polarization at $\lambda \geq 0.02 \mathrm{~s}$ maintains average electrode activity for at least 16 hours, by regenerating the electrode activity during the anodic polarization.

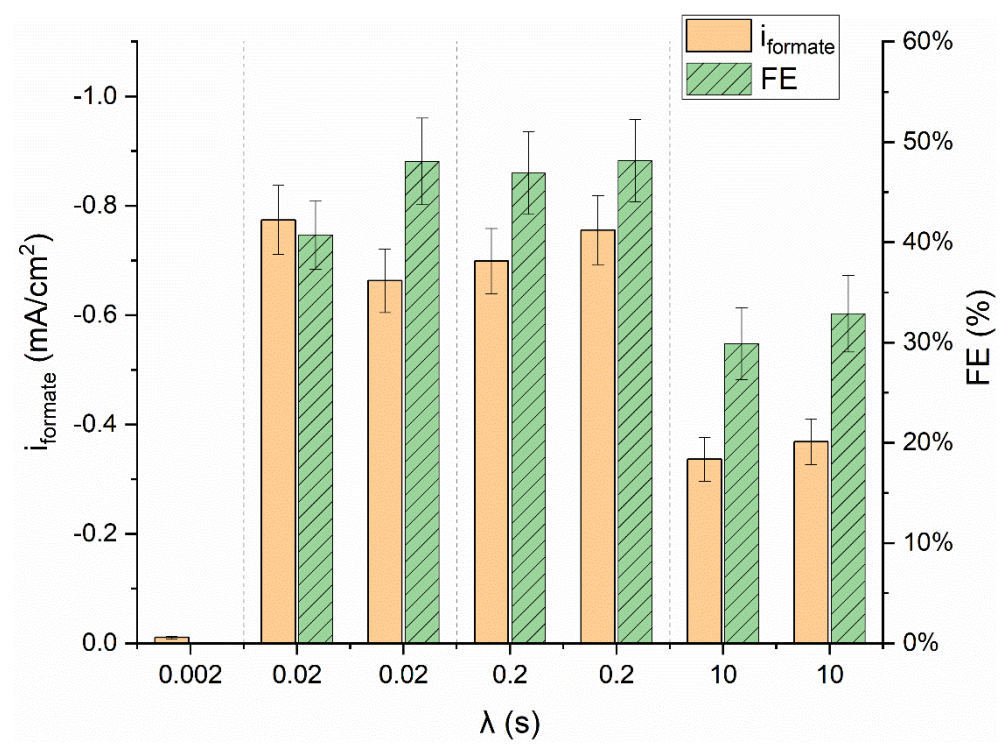

Figure 3.3: Effect of symmetric waves $\left(t_{\text {anodic }}=t_{\text {cathodic }}\right)$ on partial current density to formate (left-axis) and Faraday efficiency to formate (right-axis), determined after 16 hours in an electrolyte containing $1 \mathrm{M} \mathrm{KHCO}+1 \mathrm{mM} \mathrm{KHCOO}$.

To investigate the effect of the anodic polarization time $\left(\mathrm{t}_{\text {anodic }}\right)$ on the FE to formate, $\mathrm{t}_{\text {anodic }}$ was varied between 0 and $5 \mathrm{~s}$, adjusting $\mathrm{t}_{\text {cathodic }}$ between 95 and $100 \mathrm{~s}$, to maintain a total cycle time of 100s. Cathodic and anodic potentials of $-1.1 \mathrm{~V}$ and $+0.1 \mathrm{~V}$ vs RHE, respectively, were again applied. Figure $3.4 \mathrm{~A}$ shows a clear increase of $i_{\text {formate }}$ with increasing anodic polarization time. However, a clear trend in FE is not observed (Figure 3.4B), suggesting the anodic treatment of the electrode might also favor hydrogen evolution rates, for example due to roughening of the electrode surface during an experiment. Although not as high as observed for combination of short anodic and cathodic pulses, the FE is significantly improved as compared to chrono-amperometry measurements of 16 hours.

With increasing $\mathrm{t}_{\text {anodic }}$, anodic processes become more pronounced, as observed from the anodic to cathodic charge ratio in Figure 3.4C. For the applied conditions, the anodic charge does not constitute more than $5 \%$ of the total charge. Figure $3.4 \mathrm{D}$ shows that for very low 
anodic charge $\left(\mathrm{Q}_{\text {anodic }}=0.09 \mathrm{C}\right.$ at $\left.\mathrm{t}_{\text {anodic }}=0.1 \mathrm{~s}\right)$ there is significant charge to formate $\left(\mathrm{Q}_{\text {formate }}\right.$ $=5.2 \mathrm{C}$ ). The relatively small anodic charge compared to the cathodic charge to formate, indicates that a catalyst activation/regeneration process occurs rather than a stoichiometric process. The process does not reach completion within the 5 seconds of anodic polarization, as the activity does not reach a plateau value, but keeps increasing (Figure 3.4A). However, as little as $0.1 \mathrm{~s}$ anodic polarization every $100 \mathrm{~s}$ is sufficient to significantly enhance to average activity of the $\mathrm{Pb}$ electrode.
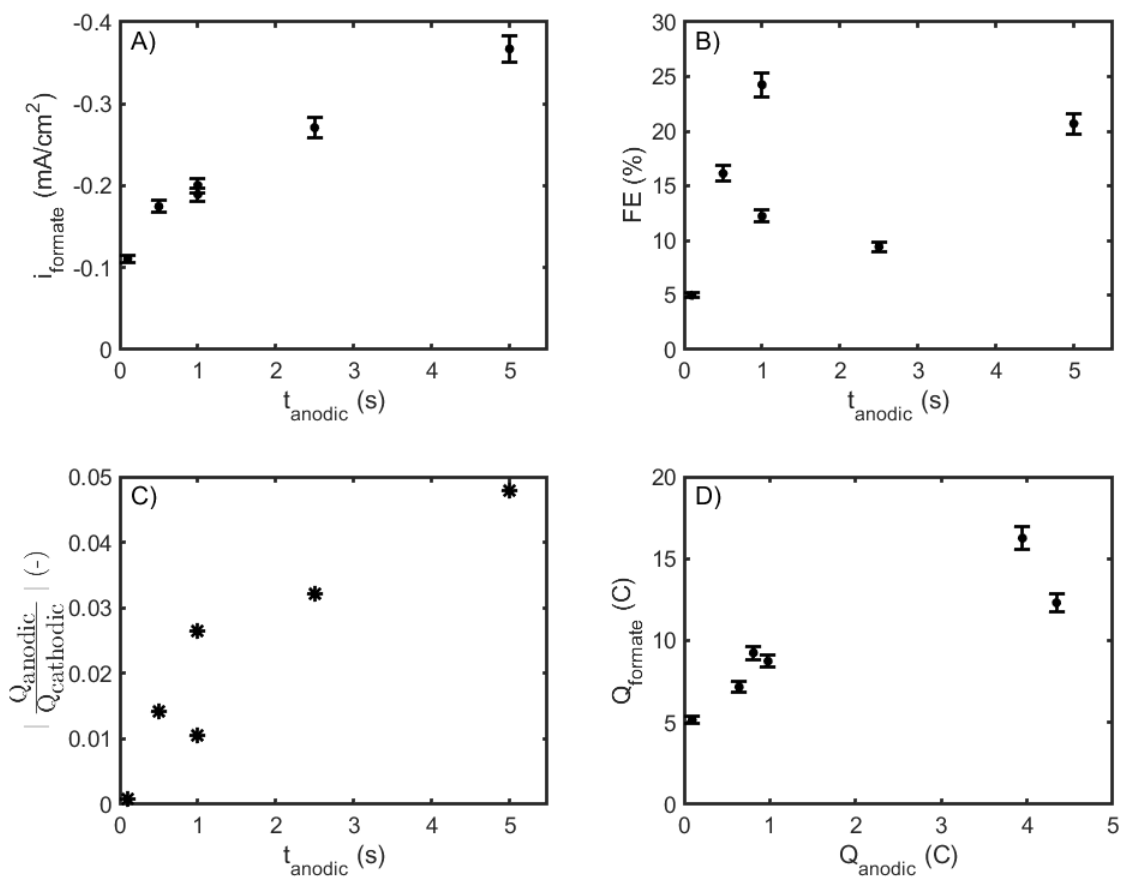

Figure 3.4: Effect of varying tanodic at a total cycle time of $100 \mathrm{~s}$, for 16 hour experiments in $1 \mathrm{M} \mathrm{KHCO}_{3}+1 \mathrm{mM}$ KHCOO. A) Partial current density to formate. B) Faraday efficiency to formate. C) Ratio between anodic and cathodic charge. D) Charge to formate versus anodic charge

The cathodic polarization time was varied at constant anodic polarization time of $5 \mathrm{~s}$, to study how long the regenerative effect of anodic polarization lasts. Figures $3.5 \mathrm{~A}$ and $\mathrm{B}$ show that $\mathrm{i}_{\text {formate }}$ and the FE rapidly fall-off from values of $-0.37 \mathrm{~mA} / \mathrm{cm}^{2}$ and $35 \%$ at $\mathrm{t}_{\text {cathodic }}$ of $5-10 \mathrm{~s}$, to values of $-0.09 \mathrm{~mA} / \mathrm{cm}^{2}$ and $2-3 \%$ at $\mathrm{t}_{\text {cathodic }}>200 \mathrm{~s}$. The quantity $1 / \lambda$, as shown in Figure $3.5 \mathrm{C}$, scales with the total number of cycles per experiment, as each experiment lasted 16 hours. The figure shows that $Q_{\text {anodic }}$ scales linearly with $1 / \lambda$, indicating that the average anodic charge flow per cycle is constant. The anodic over cathodic charge ratio increases with $1 / \lambda$, 
which shows that at smaller values of $\mathrm{t}_{\text {cathodic }}$ (hence large $1 / \lambda$ ), a comparatively larger amount of anodic charge flows. However, at those conditions the FE is also highest (Figure 3.5B), indicating a trade-off between high FE during cathodic polarization and production time lost due to anodic regeneration. The latter if further illustrated by Figure 3.5D which shows an

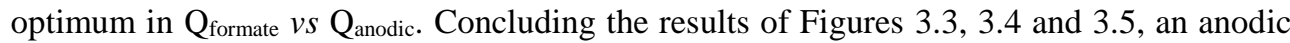
polarization time of $0.2-1 \mathrm{~s}$ appears sufficient to obtain a $\mathrm{Pb}$-surface with high FE towards formate, while the cathodic polarization time should be maintained small, and can be optimized for highest time-averaged $i_{\text {formate }}$.
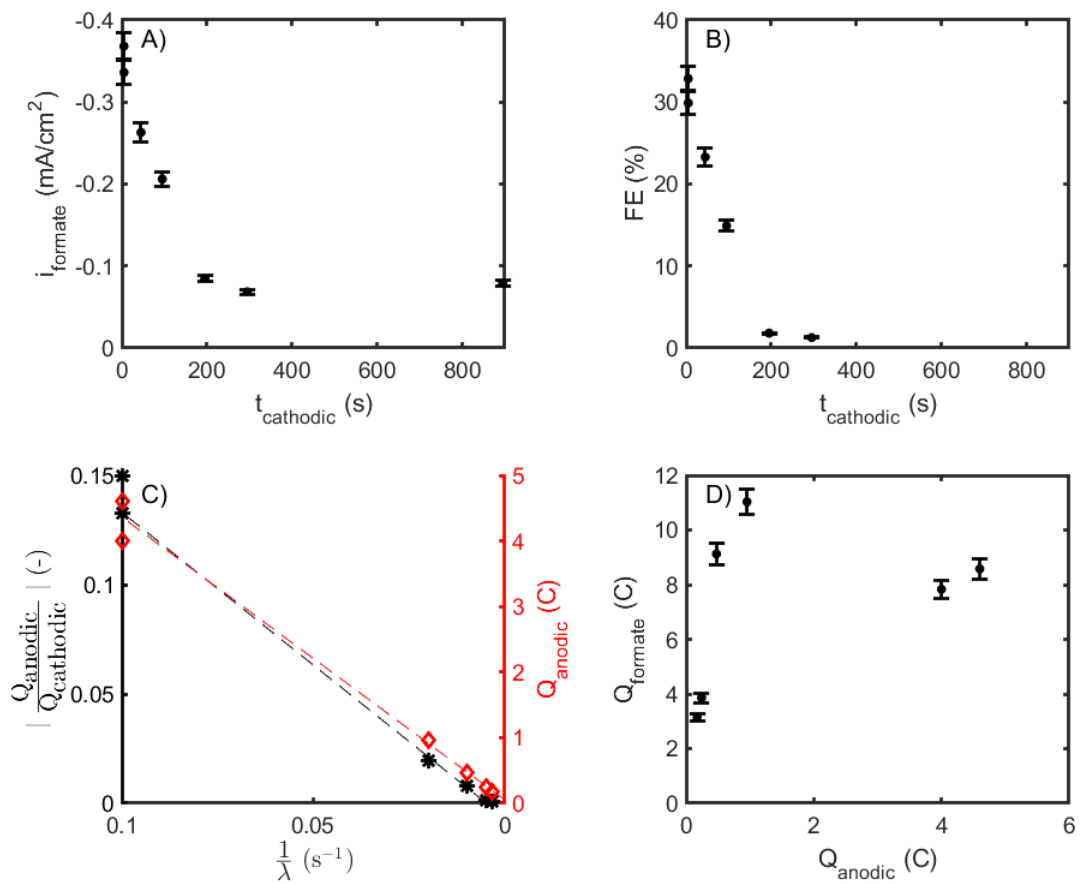

Figure 3.5: Effect of varying $t_{\text {cathodic }}$ at constant $t_{\text {anodic }}(5 \mathrm{~s})$. Concentrations were determined after 16 hours in $1 \mathrm{M} \mathrm{KHCO}_{3}+1 \mathrm{mM}$ KHCOO. A) Partial current density to formate. B) Faraday efficiency to formate. C) Ratio between anodic and cathodic current. D) Charge to formate versus anodic charge.

During the anodic polarization of the $\mathrm{Pb}$ electrode, a relatively small positive current was observed, resulting from an oxidation process. The applied anodic potential is insufficient for oxygen evolution, hence the current can either be attributed to formate/hydrogen oxidation and/or Pb oxidation. A CV study (appendix A3.3) showed no significant $\mathrm{HCOO}^{-}$oxidation peaks. Lee and Kanan attributed the improved activity of oxide derived $\mathrm{Pb}$ to the presence of $\mathrm{PbO}_{\mathrm{X}}$ species. ${ }^{10}$ Following the same train of thought, we propose that during periodic anodic polarization, a layer containing oxidized $\mathrm{Pb}$ species rapidly forms at the surface of the $\mathrm{Pb}$ 
electrode, increasing activity. During the applied cathodic polarization, the oxidized $\mathrm{Pb}$ surface layer decomposes, presumably at a slower rate than the formation, which is supported by the fast increase of $i_{\text {formate }}$ with $t_{\text {anodic }}$ as shown in Figure 3.4, and the slower decrease in $\mathrm{i}_{\text {formate }}$ with $\mathrm{t}_{\text {cathodic }}$, shown in Figure 3.5. The metastable nature of the oxidized $\mathrm{Pb}$ surface is only observed in the presence of $\mathrm{HCO}_{3}{ }^{-}$as indicated by a $\mathrm{CV}$ study in appendix A3.3. Based on Figure 3.5, the oxidized $\mathrm{Pb}$ surface created in $5 \mathrm{~s}$, takes approximately $100 \mathrm{~s}$ to be fully converted. The actual $i_{\text {formate }}$ at time $t$, would therefore respond to the applied potential as shown schematically in Figure 3.6.
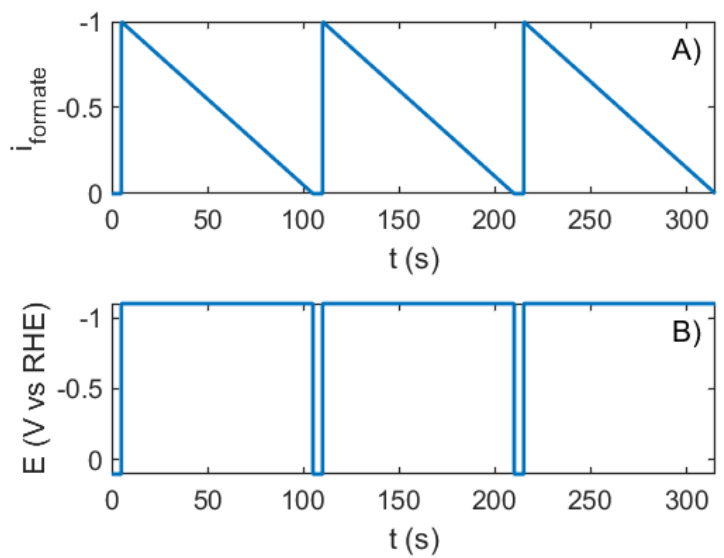

Figure 3.6: Simplified representations of A) iformate over time. B) Potential over time. During pulsed electrochemistry.

To identify the relevant oxidized phase of $\mathrm{Pb}$, a Pourbaix diagram, Figure 3.7, was constructed for $\mathrm{Pb}$, using conditions equivalent to the experimental conditions. The Pourbaix calculations incorporate the bicarbonate/carbonate acid-base equilibrium in $1 \mathrm{M} \mathrm{KHCO}_{3}$ and relevant $\mathrm{Pb}$-species (Appendix A3.4). It can be seen that the anodic polarization of the electrode is thermodynamically sufficient to produce oxidized $\mathrm{Pb}$-species in the form of $\mathrm{PbCO}_{3}$. 


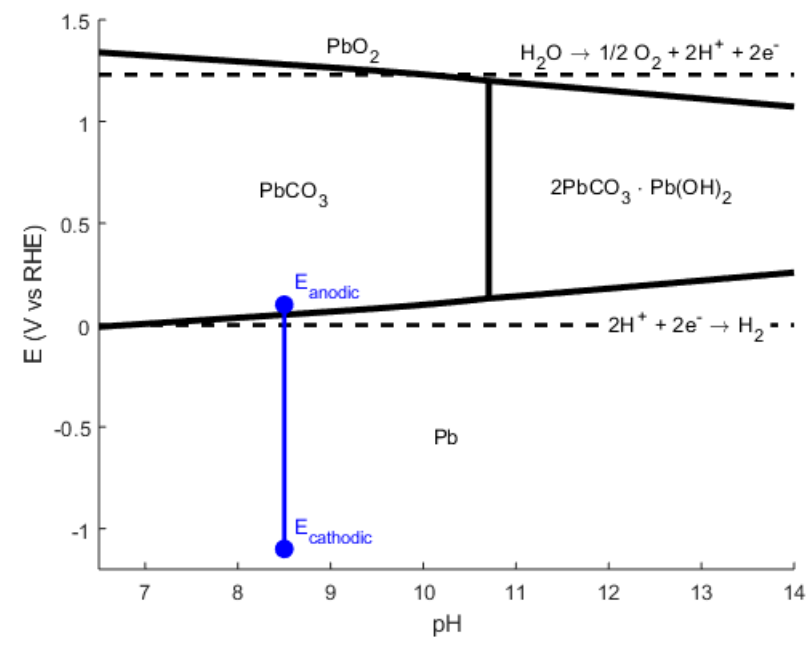

Figure 3.7: Pourbaix diagram, incorporating carbonate equilibrium (1M total carbonate concentration), showing thermodynamically stable $\mathrm{Pb}$-compounds. Dashed lines denote hydrogen and oxygen evolution, respectively. Blue dots denote cathodic and anodic potential at -1.1 and $0.1 \mathrm{~V}$ vs RHE in $1 \mathrm{M} \mathrm{KHCO}$ respectively.

To verify the thermodynamic results, in-situ Raman spectrometry was performed in $1 \mathrm{M}$ $\mathrm{KHCO}_{3}$ solution on a $\mathrm{Pb}$ electrode under anodic and cathodic polarization. Figure 3.8 shows the difference between the respective spectra. The observed Raman (difference) peak at 1055 $\mathrm{cm}^{-1}$ can be assigned to $\mathrm{CO}_{3}{ }^{-}$vibrations of $\mathrm{PbCO}_{3}$ or $2 \mathrm{PbCO}_{3} \cdot \mathrm{Pb}(\mathrm{OH})_{2} \cdot{ }^{16,17}$ This observation, combined with the thermodynamic results in Figure 3.7, suggests $\mathrm{PbCO}_{3}$ is formed during the anodic polarization of the electrode, and that $\mathrm{PbCO}_{3}$ is converted to $\mathrm{Pb}$ during cathodic polarization. The observed increased activity for formate production when $\mathrm{PbCO}_{3}$ is present, strongly suggest that $\mathrm{PbCO}_{3}$ acts as an active surface for formate production, different, but similar in oxidation state to the previously suggested $\mathrm{PbO}$-species by Lee and Kanan. ${ }^{10}$

During reduction of $\mathrm{CO}_{2}$ (cathodic polarization), the $\mathrm{PbCO}_{3}$ layer is converted: consequently, the $\mathrm{CO}_{2}$ reduction activity drops and the $\mathrm{H}_{2}$ formation rate rises. The longer the cathodic polarization time, the lower the average formate production activity and the higher the average rate of hydrogen evolution. Therefore, both $i_{\text {formate }}$ and FE drop with increasing $t_{\text {cathodic, }}$ as shown in Figure 3.5. For very long $t_{\text {cathodic }}$ the operation method approaches that of continuous operation; indeed FE approaches the continuous operation value of only a few $\%$.

In-situ spectroscopy is a necessity, as the $\mathrm{PbCO}_{3}$ layer is not fully stable when removed from solution and discoloration of the layer was observed after rinsing and drying. By taking the difference between two Raman spectra under anodic and cathodic polarization, the effect of changing polarization is isolated and confirms the thermodynamic calculations. Thereby, this 
work supports the theory that $\mathrm{Pb}^{2+}$ species are catalytically active for reduction of $\mathrm{CO}_{2}$ to formate ${ }^{10}$ and identifies $\mathrm{PbCO}_{3}$ as the active material.

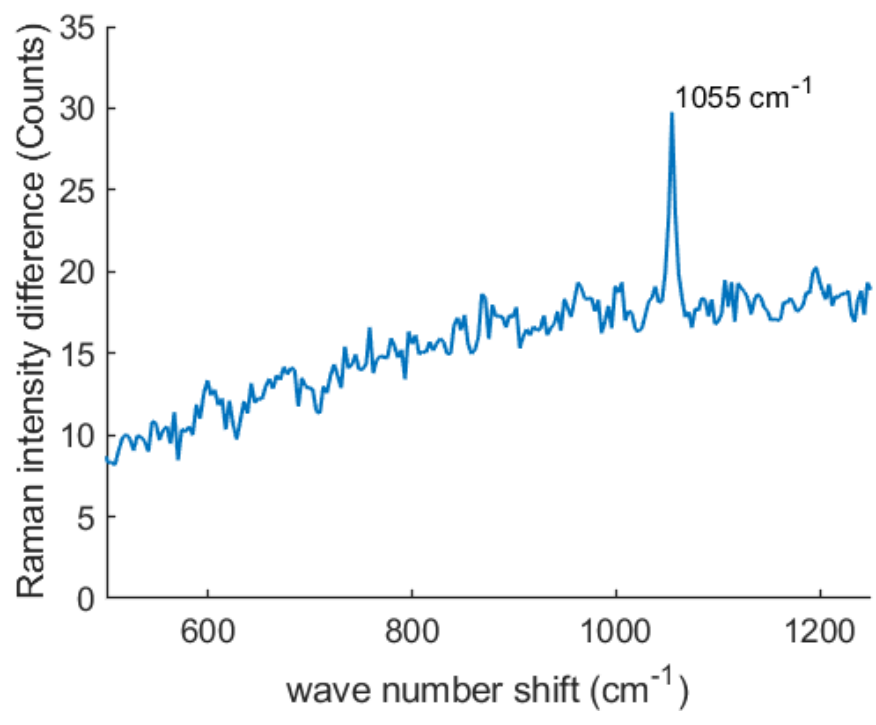

Figure 3.8: In-situ Raman difference spectrum between anodically polarized $\mathbf{P b}$, minus cathodically polarized $\mathrm{Pb}$ at 0.1 and $-1.1 \mathrm{~V}$ vs RHE, respectively, in $0.1 \mathrm{M}$ $\mathrm{KHCO}_{3}$.

Anodic regeneration has also been studied for noble metal catalysts. There, deactivation occurs via $\mathrm{CO}$ poisoning and the regeneration mechanism is based on anodic $\mathrm{CO}$ stripping, a proven method, that is still used to date. ${ }^{18-21}$ The regeneration of $\mathrm{Pb}$ electrodes cannot occur by a $\mathrm{CO}$ stripping mechanism as no $\mathrm{CO}$ formation is observed for $\mathrm{Pb}$ electrodes under $\mathrm{CO}_{2}$ reduction conditions. ${ }^{22} \mathrm{The}^{\mathrm{PbCO}_{3}}$ formation mechanism is the most likely mechanism for anodic regeneration of $\mathrm{Pb}$ electrodes.

The importance of the surface oxidation state of $\mathrm{Pb}$ cathodes shown in this work agrees with other literature and may explain some of the observed behavior. Oxygen derived $\mathrm{Pb}$ and $\mathrm{Pb}$ roughened by oxidation-reduction cycling both show increased $\mathrm{FE}$ compared to polished $\mathrm{Pb}$. 10,23 This is likely due to increased surface oxidation state, similar to our periodic anodic polarization effect. We observed $\mathrm{PbCO}_{3}$ formation in the presence of dissolved oxygen at open circuit potential, albeit at slow rate. This and the electrode deactivation over time (Figure 3.2C) may explain part of the large variation on FE reported in literature (Table 3.1).

With the focus on scale-up to industrial size, the pulsed method results in a significant increase in activity and stability. The electrodes can be reactivated without removing them from the reactor and without changing the electrolyte, which is advantageous in terms of time 
and effort needed for reactivation. Moreover, as only little anodic charge is associated with the reactivation, the energy costs for regeneration are low. Therefore, periodic anodic polarization, or pulsed electrochemistry, may be a viable operation method in industrial-size applications and could prove to be a significant process intensification.

In that regard, the toxicity of $\mathrm{Pb}$ may be an issue if it would exit the reactor as a $\mathrm{Pb}^{2+}$ contamination in the electrolyte. Fortunately, based on Figure $3.7, \mathrm{~Pb}^{2+}$ is unstable during both anodic and cathodic polarization. Therefore, the $\mathrm{Pb}^{2+}$ concentration is limited by the $\mathrm{PbCO}_{3}$ solubility $\left(\mathrm{K}_{\mathrm{sp}}=1.5 \cdot 10^{-13} \mathrm{~L}^{2} / \mathrm{mol}^{2}{ }^{24}\right)$. Recycling of the electrolyte and wastewater treatment should be sufficient to keep $\mathrm{Pb}$ emissions within acceptable levels. ${ }^{25}$

The reversible half-cell potential for reduction of $\mathrm{CO}_{2}$ to formate is $+0.01 \mathrm{~V}$ vs $\mathrm{RHE}^{\S}$. However, in this chapter and throughout literature (Table 3.1), potentials much more cathodic were applied, generally between -0.8 and $-1.2 \mathrm{~V}$ vs RHE. Consequently, cathodic overpotential alone is in the order of $1 \mathrm{~V}$. In comparison, many $\mathrm{H}_{2} \mathrm{O}$ electrolysis catalysts, at similar current density, exhibit cathodic overpotential less than $0.1 \mathrm{~V} .{ }^{26}$ If the FE would be $100 \%, 1 \mathrm{~V}$ overpotential for reduction of $\mathrm{CO}_{2}$ results in an electric energy loss of $192 \mathrm{KJ} / \mathrm{mole}$ formate. In the context of an aqueous energy storage system, that waste energy comes available as low temperature heat, with only domestic heating, in winter time, as potential use. Therefore, to increase energy efficiency, other catalysts with less overpotential should be considered for the bicarbonate-formate storage system.

$\S$ At standard conditions: $1 \mathrm{M} \mathrm{KHCO}_{3}+1 \mathrm{M} \mathrm{KHCOO}$ in equilibrium with 1 atm. partial pressure of $\mathrm{CO}_{2}$ 


\subsection{Conclusion}

Lead cathodes for electrochemical $\mathrm{CO}_{2}$ reduction show high initial Faraday Efficiency, but decreasing performance with time. In-situ periodic anodic polarization can significantly increase average current density to formate and Faraday efficiency. After 16 hours of experimental time at $-1.1 \mathrm{~V} v s$ RHE a maximum increase from $-0.03 \mathrm{~mA} / \mathrm{cm}^{2}$ and $0.6 \% \mathrm{FE}$ to $-0.73 \mathrm{~mA} / \mathrm{cm}^{2}$ and $48 \% \mathrm{FE}$ was realized by using sub-second periodic anodic polarization.

In-situ Raman spectroscopy combined with thermodynamic calculations shows that $\mathrm{PbCO}_{3}$ is formed on the surface during the anodic polarization. The increased $\mathrm{CO}_{2}$ reduction activity is attributed to this $\mathrm{PbCO}_{3}$ layer, in particular the $\mathrm{Pb}^{2+}$ surface oxidation state, which is in agreement with literature. Anodic polarization time of only $0.1 \mathrm{~s}$ is sufficient to enhance the activity and further enhancement is achieved by increasing anodic polarization time. The activity is highest for short cathodic polarization time, as activity decreases during cathodic polarization. Formate is only produced during cathodic polarization, therefore an optimum exists between cathodic and anodic polarization. The operation method provides a means to regenerate $\mathrm{Pb}$ electrodes for electrochemical $\mathrm{CO}_{2}$ reduction without removing them from the reactor or changing electrolyte and at low energy costs, which is highly relevant to commercial implementation. Unfortunately, for the purpose of this thesis, the energy efficiency of $\mathrm{Pb}$ electrodes, requiring approximately $1 \mathrm{~V}$ overpotential, is too low for application in the bicarbonate-formate system. Therefore, a more energy efficient catalyst will be considered in the next chapters. 


\section{References}

1. Du, D., Lan, R., Humphreys, J. \& Tao, S. Progress in inorganic cathode catalysts for electrochemical conversion of carbon dioxide into formate or formic acid. J. Appl. $\begin{array}{lll}\text { Electrochem. } & 47,661-678 & \text { (2017). }\end{array}$ 2. Díaz-Sainz, G. et al. CO2 electroreduction to formate: Continuous single-pass operation in a filter-press reactor at high current densities using $\mathrm{Bi}$ gas diffusion electrodes. J. CO2 Util. 34, 12-19 (2019).

3. Qiao, J., Liu, Y., Hong, F. \& Zhang, J. A review of catalysts for the electroreduction of carbon dioxide to produce low-carbon fuels. Chem. Soc. Rev. 43, (2014).

4. Bagger, A., Ju, W., Varela, A. S., Strasser, P. \& Rossmeisl, J. Electrochemical CO2 Reduction: A Classification Problem. ChemPhysChem 18, 3266-3273 (2017).

5. Rand, D. A. J. \& Moseley, P. T. Energy Storage with Lead-Acid Batteries. Electrochemical Energy Storage for Renewable Sources and Grid Balancing (Elsevier B.V., 2014). doi:10.1016/B978-0-444-62616-5.00013-9

6. Zhang, W. et al. Progress and Perspective of Electrocatalytic CO2 Reduction for Renewable Carbonaceous Fuels and Chemicals. Adv. Sci. 5, 1-24 (2018).

7. Hori, Y., Wakebe, H., Tsukamoto, T. \& Koga, O. Electrocatalytic process of CO selectivity in electrochemical reduction of $\mathrm{CO} 2$ at metal electrodes in aqueous media. Electrochim. Acta 39, 1833-1839 (1994).

8. Köleli, F. et al. Electrochemical reduction of $\mathrm{CO} 2$ at $\mathrm{Pb}$-and $\mathrm{Sn}$-electrodes in a fixed-bed reactor in aqueous K2CO3 and KHCO3 media. J. Appl. Electrochem. 33, 447-450 (2003).

9. Innocent, B. et al. Electro-reduction of carbon dioxide to formate on lead electrode in aqueous medium. J. Appl. Electrochem. 39, 227-232 (2009).

10. Lee, C. H. \& Kanan, M. W. Controlling H+ vs CO2 Reduction Selectivity on Pb Electrodes. ACS Catal. 5, 465-469 (2015).

11. MacHunda, R. L., Lee, J. \& Lee, J. Microstructural surface changes of electrodeposited $\mathrm{Pb}$ on gas diffusion electrode during electroreduction of gas-phase CO2. Surf. Interface Anal. 42, 564-567 (2010).

12. Azuma, M., Hashimoto, K., Hiramoto, M., Watanabe, M. \& Sakata, T. Electrochemical Reduction of Carbon Dioxide on Various Metal Electrodes in Low-Temperature Aqueous Media. Journal of The Electrochemical Society 137, 1772-1778 (1990).

13. Shiratsuchi, R., Aikoh, Y. \& Nogami, G. Pulsed Electroreduction of CO2 on Copper Electrodes. J. Electrochem. Soc. 140, 3479-3482 (1993).

14. Nogami, G., Itagaki, H. \& Shiratsuchi, R. Pulsed Electroreduction of CO2 on Copper Electrodes-II. J. Electrochem. Soc. 141, 1138-1142 (1994).

15. Chen, J. G., Jones, C. W., Linic, S. \& Stamenkovic, V. R. Best Practices in Pursuit of Topics in Heterogeneous Electrocatalysis. ACS Catal. 7, 6392-6393 (2017).

16. Burgio, L., Clark, R. J. H. \& Firth, S. Raman spectroscopy as a means for the identification of plattnerite ( $\mathrm{PbO} 2)$, of lead pigments and of their degradation products. Analyst 126, 222-227 (2001).

17. Lafuente, B., Downs, R. T., Yang, H. \& Stone, N. The power of databases: the RUFF project. Highlights in Mineralogical Crystallography (2015).

18. Ha, S., Larsen, R. \& Masel, R. I. Performance characterization of Pd/C nanocatalyst for direct formic acid fuel cells. J. Power Sources 144, 28-34 (2005).

19. Zhang, H. X., Wang, S. H., Jiang, K., André, T. \& Cai, W. Bin. In situ spectroscopic investigation of $\mathrm{CO}$ accumulation and poisoning on Pd black surfaces in concentrated HCOOH. J. Power Sources 199, 165-169 (2012).

20. Ha, S., Larsen, R., Zhu, Y. \& Masel, R. I. Direct formic acid fuel cells with $600 \mathrm{~mA} \mathrm{~cm}-2$ at $0.4 \mathrm{~V}$ and $22^{\circ} \mathrm{C}$. Fuel Cells 4, 337-343 (2004).

21. Lee, C. W., Cho, N. H., Nam, K. T., Hwang, Y. J. \& Min, B. K. Cyclic two-step electrolysis for stable electrochemical conversion of carbon dioxide to formate. Nat. Commun. 10, 1-8 
(2019).

22. Innocent, B. et al. FTIR spectroscopy study of the reduction of carbon dioxide on lead electrode in aqueous medium. Appl. Catal. B Environ. 94, 219-224 (2010).

23. $\mathrm{He}, \mathrm{Z}$. et al. Electrochemically created roughened lead plate for electrochemical reduction of aqueous CO2. Catal. Commun. 72, 38-42 (2015).

24. Sarig, S. \& Kahana, F. On the association between sparingly soluble carbonates and polyelectrolytes. J. Cryst. Growth 35, 145-152 (1976).

25. Zouaoui, N. et al. Electroreduction of $\mathrm{CO} 2$ to formate on amine modified $\mathrm{Pb}$ electrodes. $\mathrm{J}$. Mater. Chem. A 7, 11272-11281 (2019).

26. Wang, H. \& Gao, L. Recent developments in electrochemical hydrogen evolution reaction. Curr. Opin. Electrochem. 7, 7-14 (2018).

27. Rumble, J. CRC handbook of chemistry and physics: A ready-reference book of chemical and physical data. (CRC Press/Taylor \& Francis, Boca Raton, FL, 2018).

28. Internal corrosion of water distribution systems. (American Water Works Association Research Foundation, 1996). 


\section{Appendix}

\section{A3.1 Short time continuous experiments materials and methods}

The short time experiments, other than the ones described in section 3.2, were conducted in an in-house developed membrane-divided electrochemical cell. The $\mathrm{Pb}$ working electrode area was $6 \mathrm{~cm}^{2}(2$ by $3 \mathrm{~cm}$ ) and for each experiment a new electrode was used. The counter electrode was platinum-coated titanium (Magneto) of the same size. Both electrolytes were separates from the membrane by $1 \mathrm{~cm}$ of solution. The working electrode was a $\mathrm{Ag} / \mathrm{AgCl}$ $3 \mathrm{M} \mathrm{KCl}$ reference electrode that was built in-house. Prior to an experiment pure $\mathrm{CO}_{2}$ was sparged through solution for 15 minutes. During experiments, $\mathrm{CO}_{2}$ was also sparged through solution at $5 \mathrm{ml} / \mathrm{min}$. Both the catholyte and anolyte were $6 \mathrm{ml} 1 \mathrm{M} \mathrm{KHCO}$. The compartments were separated by a cation exchange membrane (CMI-7000, Membranes international inc., $450 \mu \mathrm{m}$ thick.).

\section{A3.2 Calculation of error bars}

Equations A3.1 and A3.2 show the error in the specific formate current density and Faraday efficiency respectively, calculated by propagation of errors. There, $\delta$ denotes the error a certain quantity. The magnitude of which was estimated. Especially at low concentrations, the errors are dominated by the uncertainty in the formate concentration, the value of which was estimated from HPLC calibration (6 concentrations, 3 repeats per concentration). At higher concentration, the errors are dominated by the uncertainty in electrolyte volume (evaporation) which results in an error of $1 \mathrm{ml}$ in the electrolyte volume for the large cell, estimated by gas flow, experimental time and vapor pressure of water. The error in the measured charge flow is $0.2 \%$, as described by the manufacturer. Typically, each experiment was performed once and selected duplo measurements are shown as separate data points in the graphs.

$$
\begin{aligned}
& \delta i_{\text {formate }}=\left(\frac{\delta c_{\text {formate }}}{c_{\text {formate }}}+\frac{\delta V}{V}\right) \cdot i_{\text {formate }} \\
& \delta F E=\left(\frac{\delta c_{\text {formate }}}{c_{\text {formate }}}+\frac{\delta V}{V}+\frac{\delta Q_{\text {net }}}{Q_{\text {net }}}\right) \cdot F E
\end{aligned}
$$

\section{A3.3 CV study formate oxidation}

Figure A3.1 compares CV's in $1 \mathrm{M} \mathrm{KHCO}_{3}$ with and without formate present in the bulk solution. There is no distinct difference in the oxidation peaks at $0.0 \mathrm{~V}$ vs RHE. Comparing the CV (Figure A3.1) to the Pourbaix diagram (Figure 3.7), it is likely that the oxidation and reduction peak at $0.0 \mathrm{~V}$ vs $\mathrm{RHE}$ are due to the transition from $\mathrm{Pb}$ to $\mathrm{PbCO}_{3}$. The broad reduction peak of the $\mathrm{PbCO}_{3}$ is an indication that the formed $\mathrm{PbCO}_{3}$ is metastable. The lack of a formate oxidation peak can be attributed to the high overpotential for formate production ( $>0.8 \mathrm{~V}$ from Figure A3.2), hence high overpotential for formate oxidation. In that case formate oxidation would not occur until a potential of $0.8 \mathrm{~V}$ vs RHE is reached. 


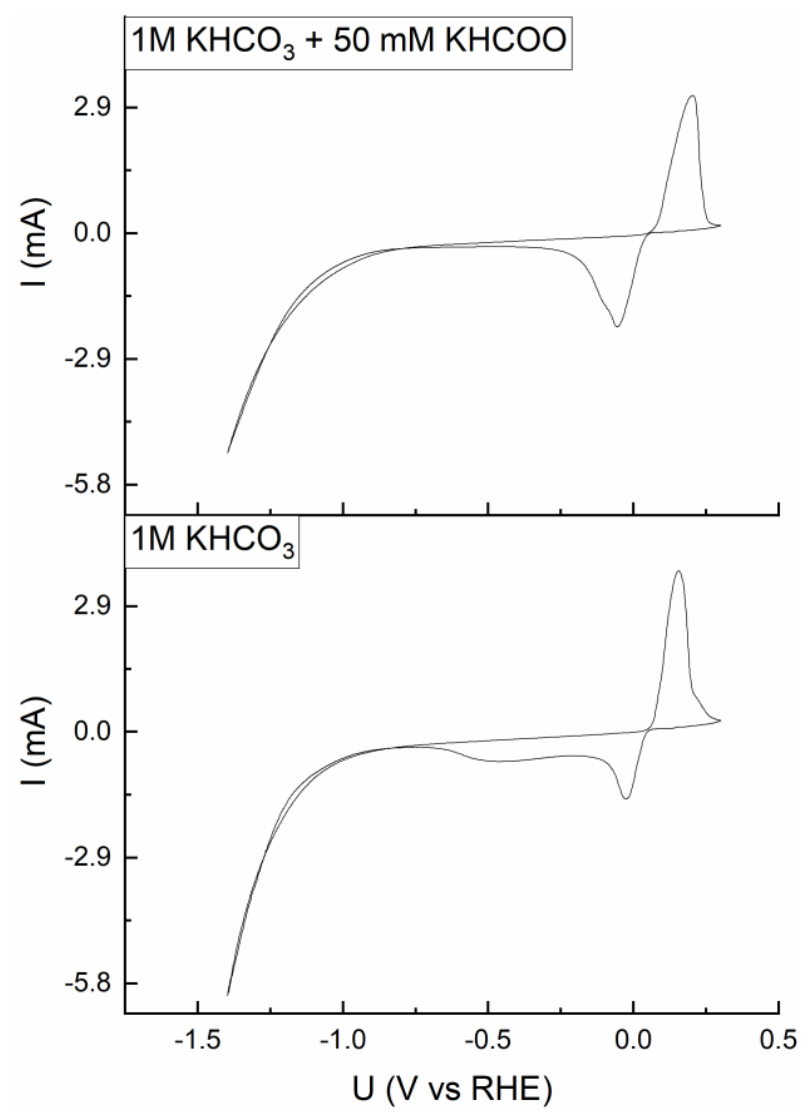

Figure A3.1: $\mathrm{CV}$ of $\mathrm{Pb}$ electrode in $1 \mathrm{M} \mathrm{KHCO}_{3}$ with and without added formate at $5 \mathrm{mV} / \mathrm{s}$

Figure A3.2 shows CV's of Pb electrodes in a 'blank' electrolyte with added formate or bicarbonate to study their effect independently. It is shown that with only supporting electrolyte, oxidation peaks are still observed, which is likely $\mathrm{PbO}$ formation. The presence of $\mathrm{HCOO}^{-}$seems to hinder this oxidation. The presence of $\mathrm{HCO}_{3}{ }^{-}$results in a distinct difference in the reduction peak at $0.0 \mathrm{~V}$ vs RHE. In the presence of $\mathrm{HCO}_{3}{ }^{-}$, the reduction peak becomes extremely broad, indicating a clear stabilisation of the oxidised surface, likely due to $\mathrm{PbCO}_{3}$ formation. 

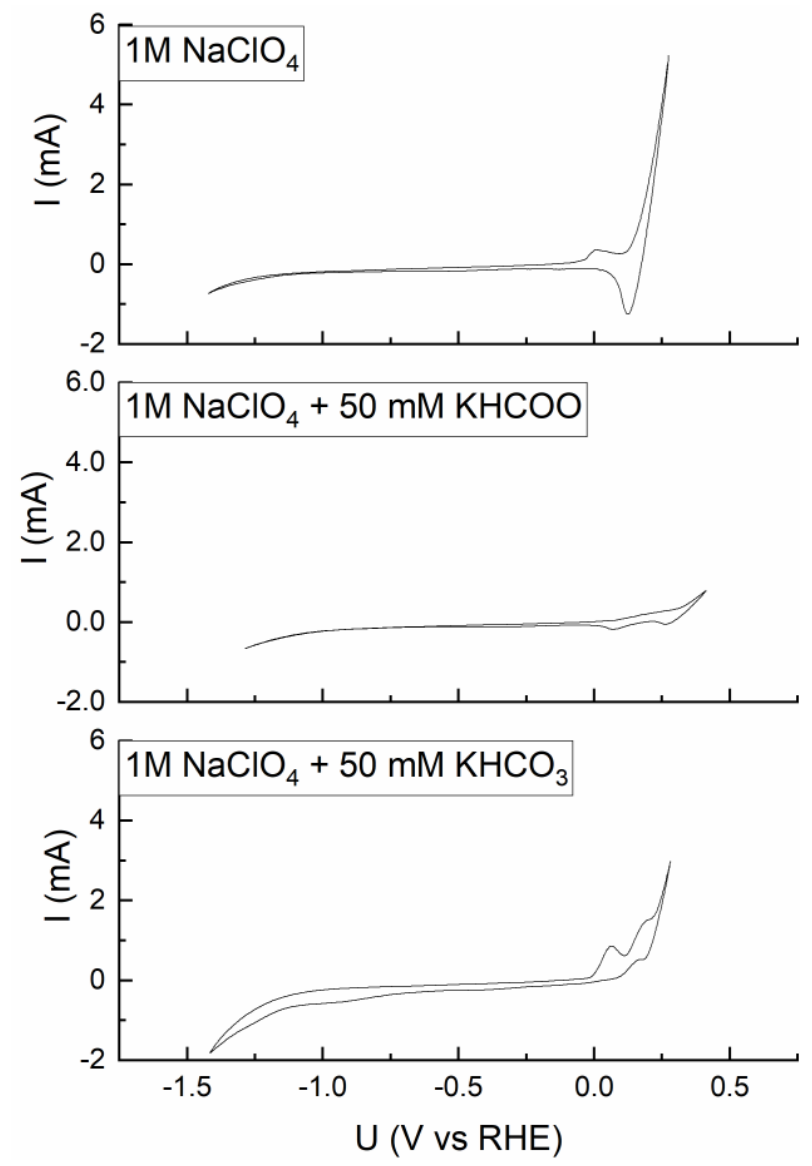

Figure A3.2: $\mathrm{CV}$ of $\mathrm{Pb}$ electrode in $\mathrm{1M} \mathrm{NaClO}_{4}$ with and without added formate or bicarbonate at $5 \mathrm{mV} / \mathrm{s}$

\section{A3.4 Pourbaix diagram calculations}

For every $\mathrm{Pb}$ species that was identified as relevant, the standard equilibrium potential $\left(\mathrm{E}^{0}\right)$ was calculated using equation A3.3 and the Gibbs free energy of formation shown in Table A3.1. In equation A3.3, $\mathrm{n}$ denotes the amount of electrons participating in the reaction and $\mathrm{F}$ is the Faraday constant. As a function of $\mathrm{pH}$ and carbonate concentration, $\mathrm{E}^{0}$ was converted to the actual equilibrium potential at the relevant $\mathrm{pH}$, using the Nernst equation A3.4. There, $\mathrm{R}$ denotes the gas constant and $\mathrm{T}$ the temperature. $\mathrm{Q}$ is defined by A3.6 for reaction A3.5. For dissolved $\mathrm{Pb}$ species, the concentration was assumed to be $1 \cdot 10^{-6} \mathrm{~mol} / \mathrm{L}$, due to the low solubility. As the carbonate concentration is dependent on $\mathrm{pH}$, this was incorporated using equation A3.7. This is a function of the initially dissolved bicarbonate concentration (1 $\mathrm{mol} / \mathrm{L}$ ) and the $\mathrm{pH} . \mathrm{K}_{1}$ is the equilibrium constant and $K_{1}=4.66 \cdot 10^{3} \cdot{ }^{27}$ Therefore, the Pourbaix diagram describes a system of initially $1 \mathrm{M} \mathrm{KHCO}_{3}$ to which lye is added, without contact/exchange with gaseous $\mathrm{CO}_{2}$. 
$\mathrm{E}^{0}=-\frac{\Delta_{\mathrm{r}} \mathrm{G}}{\mathrm{nF}}$

$\mathrm{E}=\mathrm{E}^{0}-\frac{\mathrm{RT}}{\mathrm{nF}} \ln (\mathrm{Q})$

$\mathrm{A}^{\mathrm{m}+}+\mathrm{ne}^{-} \rightarrow \mathrm{B}^{(\mathrm{m}-\mathrm{n})+}$

$\mathrm{Q}=\frac{[\mathrm{B}]}{[\mathrm{A}]}$

$\left[\mathrm{CO}_{3}^{2-}\right]=\left[\mathrm{HCO}_{3}^{-}\right]_{0} \cdot \frac{\mathrm{K}_{1} \cdot 10^{-(14-\mathrm{pH})}}{1+\mathrm{K}_{1} \cdot 10^{-(14-\mathrm{pH})}}$

Table A3.1: Standard Gibbs free energy of formation at 298.15K for selected species $^{27,28}$

\begin{tabular}{ll}
\hline Species & $\begin{array}{l}\Delta \mathrm{G}_{\mathrm{f}} \\
(\mathrm{KJ} / \text { mole })\end{array}$ \\
\hline $\mathrm{Pb}$ & 0 \\
$\mathrm{~Pb}^{2+}$ & -24 \\
$\mathrm{~Pb}^{4+}$ & 303 \\
$\mathrm{PbO}$ & -188 \\
$\mathrm{PbO}_{2}$ & -217 \\
$2 \mathrm{PbCO}_{3} \cdot \mathrm{Pb}(\mathrm{OH})_{2}$ & -1699.8 \\
$\mathrm{H}^{+}$ & 0 \\
$\mathrm{OH}^{-}$ & -157 \\
$\mathrm{CO}_{3}^{2-}$ & -528 \\
$\mathrm{H}_{2} \mathrm{O}^{2-}$ & -237 \\
$\mathrm{PbCO}_{3}$ & -626 \\
\hline
\end{tabular}






\section{Chapter 4}

\section{The effect of partial pressure of hydrogen and $\mathrm{CO}_{2}$ on rate and selectivity at $\mathrm{Pd} / \mathrm{C}$}

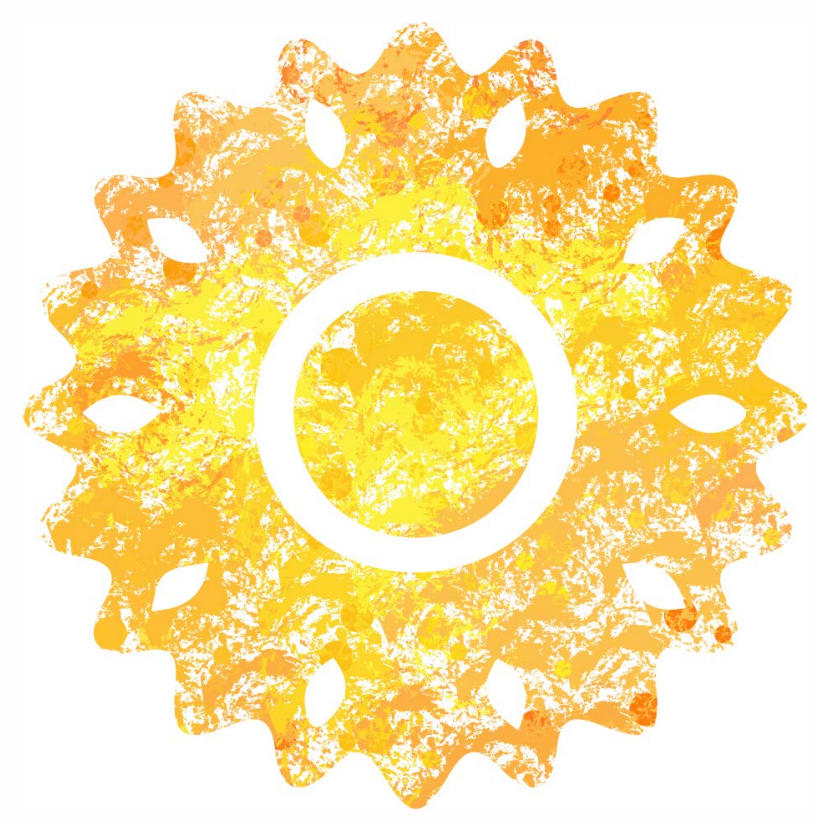

'A problem well stated is a problem half-solved'

- Charles F. Kettering - 


\begin{abstract}
Electrochemical reduction of $\mathrm{CO}_{2}$ on a $\mathrm{Pd} / \mathrm{C}$ cathode produces formate and hydrogen at low overpotentials. An increase in the partial pressure of formate in the catholyte results in a reduction of the net hydrogen evolution rate, whilst the rate to formate remains unaffected. By applying 4 bar partial hydrogen pressure, hydrogen evolution can be fully avoided at $0.05 \mathrm{~V}$ vs RHE and 1 bar partial $\mathrm{CO}_{2}$ pressure. The effect is observed during operation at various partial pressure of $\mathrm{CO}_{2}$ and applied potentials. Therefore, the partial pressure of hydrogen can be utilised to increase selectivity to formate, whilst other parameter are free to steer productivity and energy efficiency. A reactor concept that employs this principle is described and a set of potential steady state operating conditions is estimated.
\end{abstract}

This chapter is published as Blom, M. J. W., van Swaaij, W. P. M., Mul, G. \& Kersten, S. R. A. Increased hydrogen partial pressure suppresses and reverses hydrogen evolution during Pd catalyzed electrolysis of $\mathrm{CO}_{2}$. Sustainable Energy and Fuels 2020 (4) 4459-4463. 


\subsection{Introduction}

Electrocatalysts that reportedly show high intrinsic selectivity for $\mathrm{CO}_{2}$ reduction towards formate over hydrogen production and other $\mathrm{CO}_{2}$ reduction products $(\mathrm{Pb}, \mathrm{Sn}, \mathrm{Bi}, \mathrm{In})$, all require significant overpotential for $\mathrm{CO}_{2}$ reduction to occur. ${ }^{1-4}$ The overpotential is associated with activation of $\mathrm{CO}_{2}$ on the catalysts surface. ${ }^{5,6}$ However, under $\mathrm{CO}_{2}$ reduction conditions, even more overpotential is associated with the activation of water, thus they are selective towards $\mathrm{CO}_{2}$ reduction. ${ }^{4,7}$ These metals are not good electrocatalysts for $\mathrm{CO}_{2}$ reduction, but are even worse catalysts for hydrogen evolution. Energy efficient $\mathrm{CO}_{2}$ reduction requires a good catalyst that exhibits low overpotential.

Conversion of $\mathrm{CO}_{2}$ to formate at near zero overpotential $(<0.05 \mathrm{~V})$ is only observed on $\mathrm{Pd}$ based electrocatalysts and the enzyme formate dehydrogenase and its derivatives ${ }^{8-10}$, making $\mathrm{Pd}$ based catalysts especially relevant for heterogeneous, energy efficient electrocatalysis. Although $\mathrm{CO}_{2}$ reduction occurs close to the equilibrium potential, the catalyst is not intrinsically selective. When operated at less than $0.25 \mathrm{~V}$ overpotential, $\mathrm{Pd}$ based electrocatalysts produce $\mathrm{HCOO}^{-}$(reaction 4.1) with $\mathrm{H}_{2}$ as a byproduct (reaction 4.2). ${ }^{11}$ Since $\mathrm{Pd}$ is an excellent hydrogen evolution catalyst and $\mathrm{H}_{2}$ and $\mathrm{HCOO}^{-}$are both formed via palladium hydride as an intermediate, suppressing hydrogen evolution is challenging. ${ }^{9,12}$ Many recent publications try to minimize hydrogen evolution by changing the nature of the catalyst via alloying (88\% - 100\% Faraday Efficiency (FE)) ${ }^{13,14}$, doping (70\% FE) ${ }^{15}$ or (nano)structuring $(50 \%-97 \% \mathrm{FE}){ }^{16,17}$. This chapter described an alternative approach, which utilizes the reversible Pd-catalysed hydrogenation of $\mathrm{CO}_{2}{ }^{18,19}$ (reaction 4.3).

$$
\begin{aligned}
& \mathrm{CO}_{2}+\mathrm{HA}^{z+1}+2 e^{-} \rightleftarrows \mathrm{HCOO}^{-}+A^{z} \\
& 2 \mathrm{HA}^{z+1}+2 e^{-} \rightleftarrows \mathrm{H}_{2}+2 A^{z} \\
& \mathrm{CO}_{2}+\mathrm{H}_{2}+A^{z} \rightleftarrows \mathrm{HCOO}^{-}+\mathrm{HA}^{z+1}
\end{aligned}
$$

Generally, electrochemical setups for the electrochemical reduction of $\mathrm{CO}_{2}$ continuously sparge fresh $\mathrm{CO}_{2}$ through the catholyte, as is good practise, to avoid mass transfer limitations by undersaturation of the bulk electrolyte. ${ }^{20-22}$ However, $\mathrm{CO}_{2}$ sparging also strips any formed $\mathrm{H}_{2}$ from solution and pulls reaction 4.2 towards more hydrogen production. In contrast, in the absence of applied potential, $\mathrm{Pd} / \mathrm{C}$ catalyses hydrogenation of $\mathrm{CO}_{2}$ dissolved in aqueous solution at elevated hydrogen partial pressure $\left(\mathrm{p}_{\mathrm{H} 2}\right) .{ }^{19}$ Moreover, at electrochemical $\mathrm{CO}_{2}$ reduction conditions, reactions 4.2 and 4.3 were observed to occur simultaneously on $\mathrm{Pd} / \mathrm{C}$. ${ }^{23,24}$ The rate of reaction 4.3 increases with $\mathrm{p}_{\mathrm{H} 2}{ }^{19}$, whereas the rate of reaction 4.2 decreases with $\mathrm{p}_{\mathrm{H} 2}$, but the latter is mostly governed by the applied potential ${ }^{25}$. If, at a certain potential and $\mathrm{p}_{\mathrm{H} 2}$, the rates of reaction 4.2 and 4.3 are equal, net hydrogen production is zero. In a continuous reactor (without gaseous $\mathrm{CO}_{2}$ reduction products), that would correspond to an

\footnotetext{
${ }^{\dagger}$ Where A can be $\mathrm{H}_{2} \mathrm{O}, \mathrm{OH}^{-}, \mathrm{HCO}_{3}{ }^{-}, \mathrm{CO}_{3}{ }^{2-}$ or $\mathrm{HCOO}^{-}$and $\mathrm{z}$ denotes charge
} 
operating point where no external hydrogen supply is required and net no hydrogen is produced, hence formate would be the sole product.

This chapter concerns the overall kinetics of combined chemical hydrogenation and electrochemical reduction of $\mathrm{CO}_{2}$ to formate with the aim to control the net production of hydrogen and thus selectivity to formate. (Selectivity is considered instead of Faraday Efficiency, as the latter only concerns electrochemical reactions and selectivity incorporates chemical reactions as well.) To that end, first a pressurizable electrochemical cell with incorporated membrane and reference electrode has to be developed.

\subsection{Design of reactor and setup}

The electrochemical cell should meet four main criteria to perform well in the envisioned experiments. First, the cell should obviously be pressurizable. Second, the cell should have a high electrode area relative to the electrolyte volume ( $\mathrm{S} / \mathrm{V}$ ratio), to build-up measurable product concentrations in the liquid phase within reasonable time. Third, the cell should incorporate a membrane to prevent product destruction at the opposite electrode. Last, the cell should have a reference electrode to study kinetics at constant potential.

In literature, cells are described that meet three of the four criteria, but never all of them. For example, Cave et al. developed a cell with high $\mathrm{S} / \mathrm{V}$ ratio, membrane and reference electrode, which cannot operate at elevated pressure. ${ }^{26}$ During previous research within the PCS group, a cell was developed that can operate at elevated pressure and incorporates a membrane and reference electrode, but that has low S/V ratio. ${ }^{27}$ Inspiration was obtained from both designs and two key lessons learned. First, the reference electrode should be kept at the same pressure as the electrolyte, to prevent convective transport between the reference and electrolyte. Second, a flat stacked geometry allows high $\mathrm{S} / \mathrm{V}$ ratio and gas/liquid separation inside the cell. Both were incorporated in the present cell design.

The newly developed cell features a PEEK flat stacked cell body with stainless steel endplates to provide added mechanical strength (Figure 4.1). $\mathrm{Ag} / \mathrm{AgCl}$ reference electrodes are incorporated in the cell body and are connected to the electrolyte via a gas line. Therefore, no pressure difference exists between the reference and electrolyte. The cell is designed to operate as batch reactor for the liquid phases and continuous for the gas phases. 

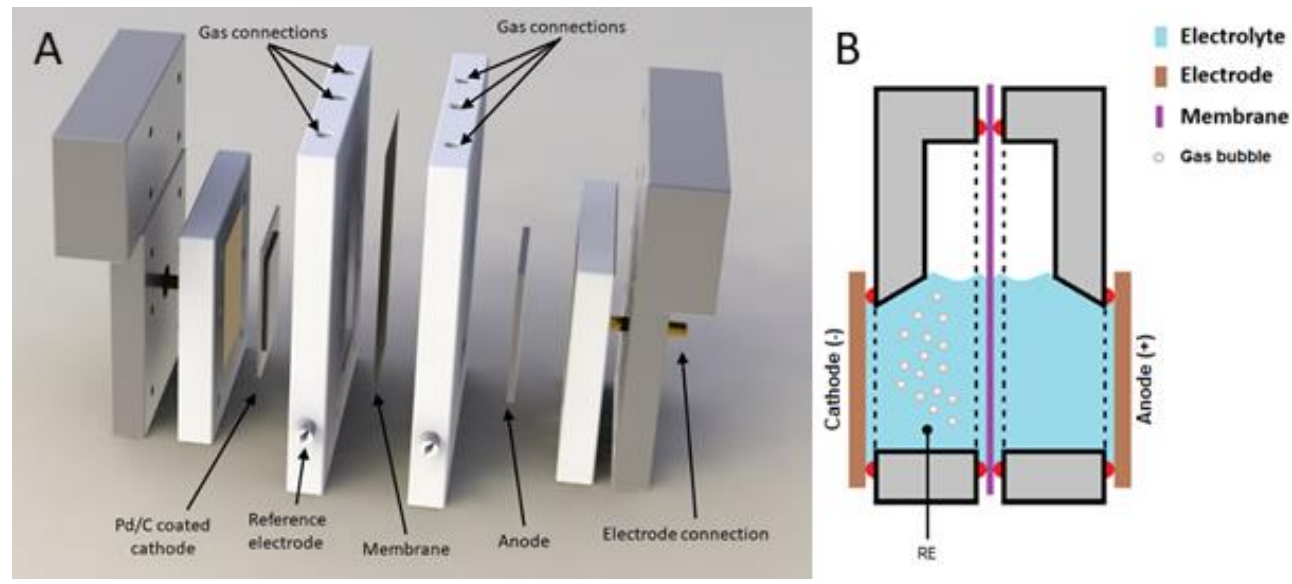

Figure 4.1: Schematic representation of electrochemical cell. A: Expanded view of electrochemical cell. B: Schematic of operating cell

It is vital that pressure within the electrochemical cell is controlled accurately. The pressure in the catholyte and anolyte should be equal during the experiment, but also during pressurization and depressurization, as any difference leads to transmembrane pressure drop, potentially damaging the membrane. The setup, shown in Figure 4.2, minimizes transmembrane pressure drop.

Feed gas to the catholyte is mixed before entering the reactor. The gas on the anolyte side is pure argon. The gas ratio and flow is controlled via mass flow controllers (MFCs a1 and c1c3). Pressure safety valves (PSVs) are in place to prevent over-pressurization. The pressure in the catholyte is controlled via MFC-c2, which is adjusted based on the set pressure. The pressure in the anolyte follows the pressure in the catholyte, via backpressure regulator a1 (BPR-a1). The BPR senses the pressure in the catholyte compartment and uses this as a setpoint for the pressure in the anode compartment. By ensuring that the gas flow to the anolyte compartment is always larger than the gas flow to the catholyte compartment, equal pressure is maintained, also during (de)pressurization. 


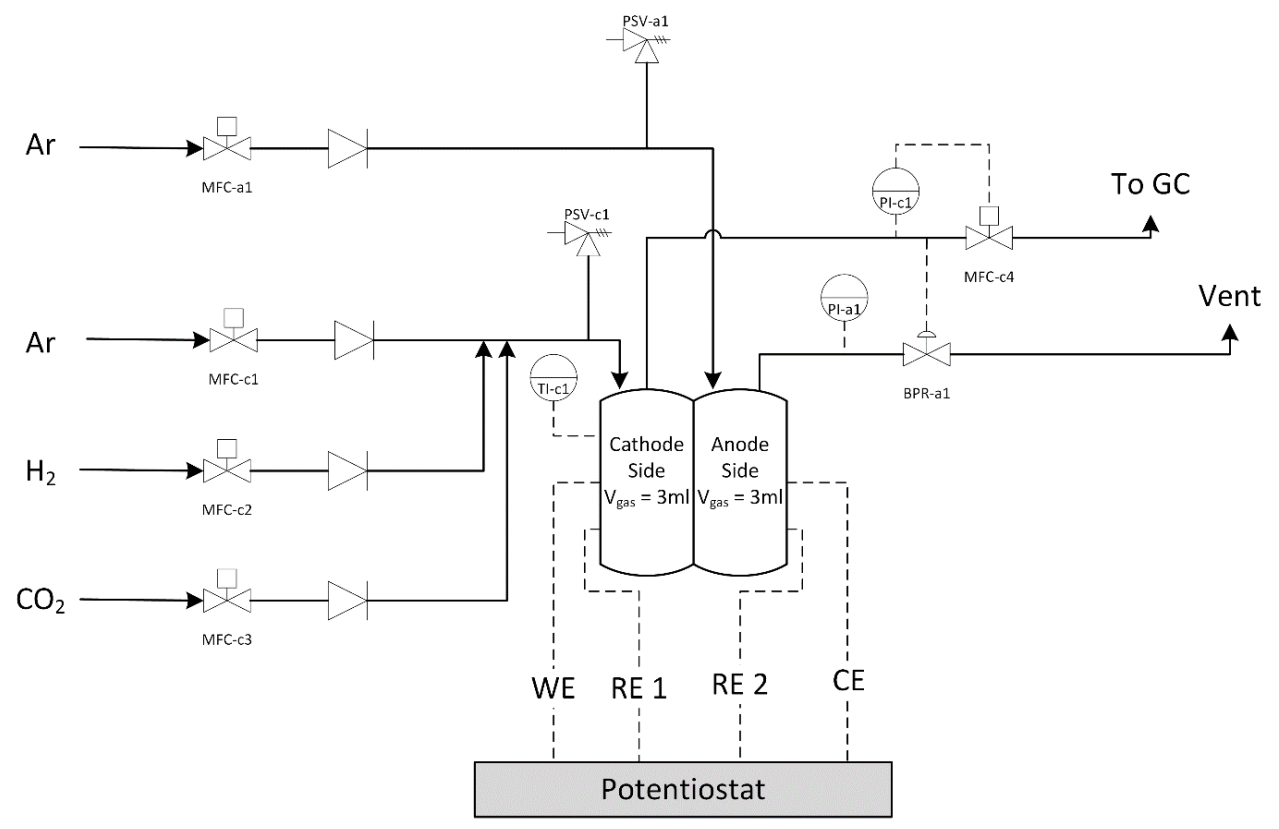

Figure 4.2: Flow diagram of electrochemical setup

\subsection{Experimental procedure}

Electrochemical reduction of $\mathrm{CO}_{2}$ was performed on $\mathrm{Pd} / \mathrm{C}$ coated titanium plate electrodes. Each experiment took 60 minutes and formate was quantified by HPLC afterwards. Consequently, the hydrogen production was calculated by the difference from the accumulative charge and production of formate.

The electrochemical cell was assembled with the $\mathrm{Pd} / \mathrm{C}$ electrode as working electrode (WE) and dimensionally stable anode as counter electrode (CE), both 2 by $3 \mathrm{~cm}$ in size. Bot electrodes were spaced $1 \mathrm{~cm}$ from the membrane. A cation exchange membrane (CEM) (CMI-7000, membranes international inc.) was used in all experiments. Both anolyte and catholyte were $6 \mathrm{ml} 1 \mathrm{M} \mathrm{KHCO}_{3}$ solution. Total gas flow to the catholyte was kept constant at $5 \mathrm{mln} / \mathrm{min}$, gas flow to the anolyte was $10 \mathrm{mln} / \mathrm{min}$ and total pressure during electrolysis was kept at 7 bara.

Pressurization of the reactor takes approximately $20 \mathrm{~min}$, which is enough time to equilibrate the gas and liquid phase. Depressurization takes about 1 minute. During (de)pressurization, no potential is applied, but hydrogenation does occur to some extent (reaction 4.3). The amount of formate produced during this period was quantified by only performing pressurization and depressurization. In data analysis that amount of formate was subtracted from the total amount of formate produced, therefore the data in this chapter accurately represents the processes that occur during pressurized electrochemistry. 
All potentials were measured versus an $\mathrm{Ag} / \mathrm{AgCl}(3 \mathrm{M} \mathrm{KCl})$ reference electrode and were converted to the Reversible Hydrogen Electrode (RHE) scale. Equilibrium pH is dependent on the $\mathrm{CO}_{2}$ pressure in the cell, hence was calculate based on this equilibrium, as described in the appendix of chapter 2 .

The RHE is defined as the thermodynamic equilibrium potential of the hydrogen evolution reaction at 1 bar $\mathrm{H}_{2}$ partial pressure under experimental (electrolyte) conditions. On the RHE scale, the thermodynamic electrochemical driving force for formate production is unaffected by $\mathrm{pH}$. The thermodynamic driving force for hydrogen evolution is affected by $\mathrm{p}_{\mathrm{H} 2}$ as per Nernst's law. Since $\mathrm{H}_{2}$ participates in the hydrogen evolution reaction, but not in the formate formation reaction, it is impossible to maintain the same thermodynamic driving force to both reactions when varying $\mathrm{pH}_{2}$. In experiments, the driving force for formate production was kept constant when constant potential versus RHE is indicated.

\section{Preparation of $\mathrm{Pd} / \mathrm{C}$ electrode}

Ti foil was cut into pieced of $30 \mathrm{~mm}$ by $40 \mathrm{~mm}$ and cleaned by boiling in $1 \mathrm{M}$ oxalic acid solution for 2 hours and consecutive rinsing with water. Carbon paper was cut into $20 \mathrm{~mm}$ by $30 \mathrm{~mm}$ pieces and attached to the Ti foil with graphite based conductive adhesive. The adhesive was cured at $60^{\circ} \mathrm{C}$ for 1 hour. This formed the electrode backbone.

Catalyst ink was prepared by mixing $50 \mathrm{mg} \mathrm{Pd} / \mathrm{C}$ (5 wt.\% Pd) with $2 \mathrm{ml}$ isopropanol and 0.5 ml Fumion solution. The mixture was sonicated for $30 \mathrm{~min}$. $200 \mu \mathrm{L}$ of catalyst ink was adsorbed into the carbon paper of the electrode backbone. The loaded electrode was then dried in an oven at $60^{\circ} \mathrm{C}$ for 1 hour. This resulted in a catalyst loading of $0.67 \mathrm{mg} / \mathrm{cm}^{2} \mathrm{Pd} / \mathrm{C}$ or $0.033 \mathrm{mg} / \mathrm{cm}^{2} \mathrm{Pd}$.

$\mathrm{KHCO}_{3}(99.7 \%)$ and 5 wt.\% $\mathrm{Pd} / \mathrm{C}$ were purchased from Merck. Fumion FAA-SOLUT-10 ionomer solution (10 wt.\% in NPM) was purchased from Fumatech GmbH. Titanium foil $0.89 \mathrm{~mm}(99.7 \%)$ and graphite conductive adhesive were purchased from Alfa Aesar. CeTech GDS810 carbon paper was purchased from fuel cell store. CMI-7000 cation exchange membrane (CEM) was purchased from Membranes International inc. A dimensionally stable anode (DSA) was acquired from Magneto Special Anodes B.V. Milli-Q water was used for all solutions and water based cleaning procedures. All chemicals were used as received without further purification.

\section{HPLC analysis and gas chromatography}

After an experiment, the formate concentration in the catholyte was determined with HPLC. A Hiplex-H column was used in an Agilent Technologies 1200 series HPLC, with $5 \mathrm{mM}$ $\mathrm{H}_{2} \mathrm{SO}_{4}$ in milli-Q as eluent. The column was at $65^{\circ} \mathrm{C}$ and eluent flow was $0.6 \mathrm{ml} / \mathrm{min}$. Formate was detected with a Refractive index detector (RID) and retention time was 14.8 minutes. 
Occasionally, the gas catholyte off-gas was analyzed with on-line GC analysis. The GC was an Interscience compact GC equipped with thermal conductivity detector (TCD) and flame ionization detector (FID). The TCD was used for CO detection and no significant amounts $(<0.2 \% \mathrm{FE})$ were formed during experiments. The FID was used for methane and higher hydrocarbon detection; no significant amounts of hydrocarbons were detected.

When no hydrogen pressure was applied to the system, the produced hydrogen could be measured by GC and an overall charge balance checked. Although the GC is not optimal for measuring $\mathrm{H}_{2}$ in the experimental concentration range, the charge balance closure never fell outside the $93 \%-103 \%$ range. Analysis of the gas phase is the largest contributor to the error in charge balance closure, due to errors in the GC measurements and relatively large amount of volume in piping, control features and safety features compared to the reactor volume. Note that reported $\mathrm{H}_{2}$ evolution rates are calculated by difference from charge flow and formate production (measured by HPLC).

\section{Operating regime}

To measure catalyst behaviour accurately, the applied conditions are such that mass transport effects in the catholyte are minimized. The mass transfer properties of the cell were characterized using potassium ferricyanide $\left(\mathrm{K}_{3} \mathrm{Fe}(\mathrm{CN})_{6}\right)$ and potassium ferrocyanide $\left(\mathrm{K}_{4} \mathrm{Fe}(\mathrm{CN})_{6}\right)$. Via linear scan voltammetry at various concentrations, under stagnant conditions a mass transfer coefficient $(\mathrm{Km})$ of $1.5 \cdot 10^{-6} \mathrm{~m} / \mathrm{s}$ was obtained which could be increased to $1.2 \cdot 10^{-5} \mathrm{~m} / \mathrm{s}$ by a stirrer bar. Compensating for the difference in diffusion coefficient $\left(\mathrm{D}_{\mathrm{CO} 2}=1.9 \cdot 10^{-9} \mathrm{~m}^{2} / \mathrm{s}\right.$ and $\left.D_{\text {ferricyanide }}=0.75 \cdot 10^{-9} \mathrm{~m}^{2} / \mathrm{s}\right)$, the $\mathrm{Km}$ values correspond to mass transfer limited $\mathrm{CO}_{2}$ reduction currents of $2.2 \mathrm{~mA} / \mathrm{cm}^{2}$ in the absence of mixing and $18 \mathrm{~mA} / \mathrm{cm}^{2}$ with stirring at 1 bar partial $\mathrm{CO}_{2}$ pressure. The latter is a typical value for liquid phase systems without gas diffusion electrodes, regarding $\mathrm{CO}_{2}$ reduction to 2 electron products. ${ }^{28,29}$

Mass transfer limitations can occur between the electrode surface and bulk solution (external limitations) or inside the porous electrode (internal limitations). External $\mathrm{CO}_{2}$ mass transfer effects were evaluated, by changing the flow rate of pure $\mathrm{CO}_{2}$ and assessing the average rate to formate. Only when the $\mathrm{CO}_{2}$ flow was zero, there was a significant effect, as shown in Figure A4.3. Therefore, external $\mathrm{CO}_{2}$ mass transfer effects play no significant role in the experiments. To prevent significant internal mass transfer limitations, the $\mathrm{CO}_{2}$ reduction rate as function of potential was determined. Then, all measurements were performed at potential less cathodic, resulting in a rate below the maximum observed rate. Therefore, although the maximum observed rate may or may not be mass transfer limited, experiments at less cathodic potential are definitely below the absolute mass transfer limit.

The gas supplied to the catholyte is sparged though a fine, small glass fritte, which assures abundant small bubbles. The small bubbles facilitate mass exchange of $\mathrm{CO}_{2}$ and $\mathrm{H}_{2}$ between the gas phase and electrolyte and they facilitate mixing. The maximum transfer of hydrogen to the electrode surface was quantified, by anodically polarizing a Pt electrode and measuring 
the current, whilst varying the hydrogen partial pressure. Mass transfer of hydrogen was found to be not rate determining for the $\mathrm{CO}_{2}$ hydrogenation reaction (Figure A4.2). During electrochemistry, under net hydrogen production conditions, hydrogen mass transfer can never be rate limiting as it is then generated at the active sites. Given these conditions, data in this chapter is representative for true catalyst behaviour. Overall, the reactor facilitates measurements in the kinetically limited regime over a wide (partial) pressure range, whilst maintaining accurate potential control.

\section{Repeatability of electrode performance}

$\mathrm{Pd} / \mathrm{C}$ electrodes are known to deactivate under electrochemical $\mathrm{CO}_{2}$ reduction conditions. This deactivation is mostly reversible, with the exception of a small initial deactivation. ${ }^{9}$ Therefore, the electrode was first used in a standard experiment and the accompanying data was omitted. Between experiments, the electrode was regenerated by 30 s anodic polarization at $1.3 \mathrm{~V}$ vs RHE. That resulted in reproducible results, as shown in Figure A4.3. The standard deviation over the faraday efficiency is 2.7 percent point.

\subsection{Results}

The effect of hydrogen partial pressure on the net production of hydrogen was studied under three different conditions: at $-0.05 \mathrm{~V}$ vs RHE and $\mathrm{p}_{\mathrm{CO} 2}=1$ bar, at $-0.10 \mathrm{~V}$ vs RHE and $\mathrm{p}_{\mathrm{CO} 2}=1$ bar, and at $-0.05 \mathrm{~V}$ vs $\mathrm{RHE}$ and $\mathrm{p}_{\mathrm{CO} 2}=3$ bar, respectively. Under all conditions, the total pressure was maintained at 7 bar and $\mathrm{H}_{2} / \mathrm{Ar}$ partial pressures were varied. Thereby, the effect of $\mathrm{p}_{\mathrm{H} 2}$ is studied, with minimal bias from changes in flow, mixing (induced by gas bubbles) and $\mathrm{CO}_{2}$ concentration.

The results, presented in Figure 4.3, show that under all conditions the average overall hydrogen production rate is significantly decreased by increasing the partial pressure of hydrogen. The effect is most pronounced at $-0.05 \mathrm{~V}$ vs $\mathrm{RHE}$ and partial $\mathrm{CO}_{2}$ pressure $\left(\mathrm{p}_{\mathrm{CO} 2}\right)$ of 1 bar. At high enough $\mathrm{p}_{\mathrm{H} 2}$, overall hydrogen production can be prevented and can even become negative, implying hydrogen consumption, which must be via reaction 4.3. A higher cathodic potential (-0.10 V vs RHE) results in a higher average rate to $\mathrm{H}_{2}$. This is a result of the increased electrochemical driving force for hydrogen evolution. At higher $\mathrm{CO}_{2}$ partial pressure the rate to $\mathrm{H}_{2}$ also increases, presumably due to kinetic effects induced by an increased acidity of the electrolyte. ${ }^{25}$ When $\mathrm{p}_{\mathrm{CO} 2}$ is increased from 1 to 3 bar, the proton concentration also increases threefold (Table A4.1) and a first order dependence of hydrogen evolution rate on the concentration of protons ${ }^{25}$ agrees with the threefold increase of hydrogen production at $\mathrm{p}_{\mathrm{H} 2}=0$ bar (Figure 4.3). Extrapolation of the data indicates that also at more cathodic potential and at higher $\mathrm{CO}_{2}$ partial pressure, an operating point exists where overall hydrogen production equals zero. 


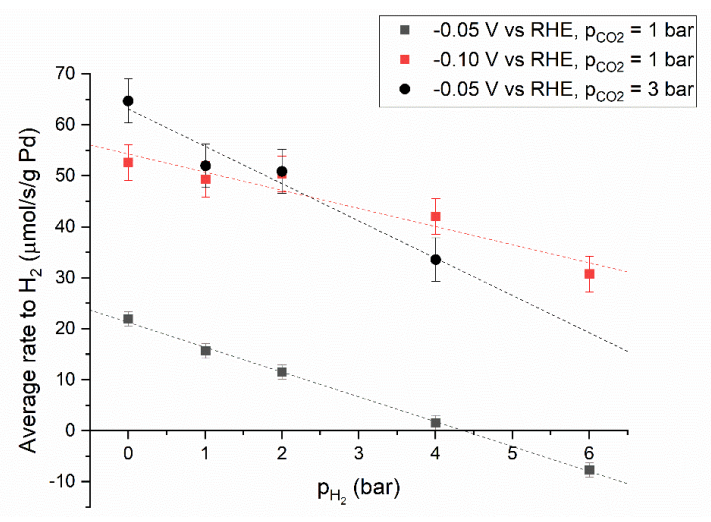

Figure 4.3: Hydrogen production during electrochemical reduction of $\mathrm{CO}_{2}$ in $1 \mathrm{M}$ $\mathrm{KHCO}_{3}$ sparged with a mixture of $\mathrm{CO}_{2}$, $\mathrm{Ar}$ and $\mathrm{H}_{2}$ at $\mathrm{p}_{\text {total }}=7 \mathrm{bar}$.

The hydrogen partial pressure does not significantly influence the average rate to formate (Figure 4.3 and appendix A4.1). This was observed for applied potentials of $-0.05 \mathrm{~V}$ and $0.10 \mathrm{~V}$ vs RHE, and at higher $\mathrm{CO}_{2}$ partial pressure of 3 bar. The average rate to formate increases at more negative cathodic potential and is similar to values reported in literature (6-52 $\mu \mathrm{mole} / \mathrm{s} / \mathrm{g} \mathrm{Pd}$ ) at comparable conditions ${ }^{9,15}$. Furthermore, the rate to formate increases with increased partial pressure of $\mathrm{CO}_{2}$, which is a continuation of the trend observed by others at partial pressures of $\mathrm{CO}_{2}$ below 1 bar. ${ }^{9}$ Both effects are studies further in the absence of exogenous hydrogen.

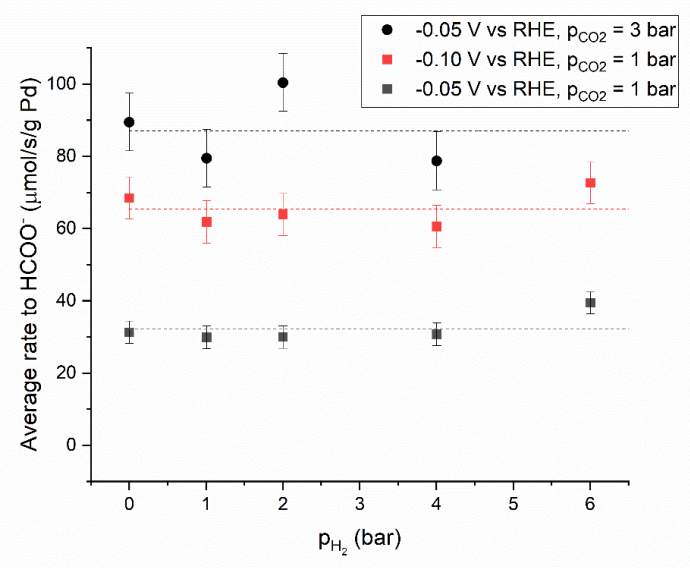

Figure 4.4: Formate production during electrochemical reduction of $\mathrm{CO}_{2}$ in $1 \mathrm{M}$ $\mathrm{KHCO}_{3}$ sparged with a mixture of $\mathrm{CO}_{2}$, $\mathrm{Ar}$ and $\mathrm{H}_{2}$ at ptotal $=7 \mathrm{bar}$. Average of data sets plotted as guide to the eye. 
First the effect of $\mathrm{CO}_{2}$ partial pressure is studied. Literature reports a first order dependence of the rate to formate on the partial pressure of $\mathrm{CO}_{2}$ between 0-1 bar, as a result of rate limiting $\mathrm{CO}_{2}$ adsorption. ${ }^{9}$ In this chapter the range between 1-7 bar was explored (Figure 4.5). Clearly, the $\mathrm{CO}_{2}$ pressure has a positive effect on the production rate of formate, but the effect decreases at higher $\mathrm{p}_{\mathrm{CO} 2}$, indicating $\mathrm{CO}_{2}$ adsorption is not (fully) rate limiting at higher $\mathrm{p}_{\mathrm{CO} 2}$. Furthermore, Figure 4.4 displays a monotonic increase in the rate towards hydrogen evolution with $\mathrm{p}_{\mathrm{CO} 2}$, which is an effect of increasing acidity of the electrolyte improving hydrogen evolution kinetics. ${ }^{25}$ The mechanistic origin of these effects is studied in chapter 5 .

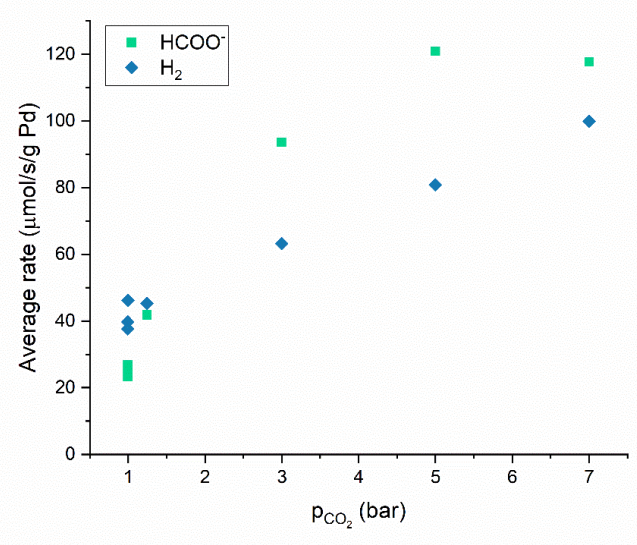

Figure 4.5: Formate and hydrogen production during electrochemical reduction of $\mathrm{CO}_{2}$ at $-0.10 \mathrm{~V}$ vs $\mathrm{RHE}$ in $1 \mathrm{M} \mathrm{KHCO}_{3}$ sparged with $\mathrm{CO}_{2}$.

When the electrochemical driving force is increased by applying more cathodic potential, the rates to formate and hydrogen both increase initially (Figure 4.6A). At potentials more cathodic than $-0.15 \mathrm{~V}$, a decrease in both rates is observed. This observation is in agreement with literature and attributed to minor amounts of electrochemically produced $\mathrm{CO}$, which poison the electrode. ${ }^{9,15}$ The deactivation is clearly visible in a plot of current over time (Figure 4.6B). Experiments at mild overpotential reach a quasi steady state, whereas current decrease throughout experiments at more cathodic potential. Although initial currents increase with more cathodic potential, the deactivation results in a lower average range over the full course of the experiment. During all other experiments in this chapter, potentials of $0.10 \mathrm{~V}$ and less cathodic were used and deactivation was monitored, the limit its effect. 

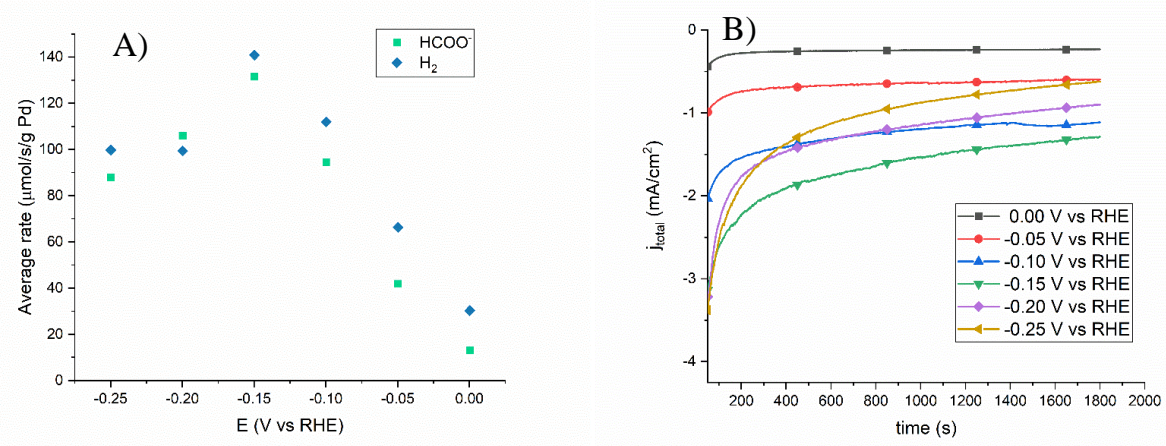

\section{Figure 4.6: A) Formate and hydrogen production during electrochemical reduction of $\mathrm{CO}_{2}$ in $1 \mathrm{M} \mathrm{KHCO}$ sparged with $\mathrm{CO}_{2}$ at 1 bar. B) Current over time for data in A}

\subsection{Discussion}

This chapter focusses on the design of the electrochemical cell, experiments therein and implication for the bicarbonate-formate energy storage system. A detailed analysis regarding the reaction kinetics and mechanism follows in Chapter 5. Summarizing the experimental results of this chapter, three parameters were studied. With increasing $\mathrm{p}_{\mathrm{H} 2}, \mathrm{r}_{\mathrm{H} 2}$ decreases and the $\mathrm{r}_{\mathrm{HCOO}}$ is unaffected. By increasing $\mathrm{p}_{\mathrm{CO} 2}, \mathrm{r}_{\mathrm{H} 2}$ increases and also $\mathrm{r}_{\mathrm{HCOO}}$ increases, but up to a maximum. Lastly, both rates increase with more cathodic potential, but too cathodic potential (<-0.15 V vs RHE) leads to fast catalyst deactivation.

During the charge step of the bicarbonate-formate system, a high reaction rate towards $\mathrm{HCOO}^{-}$is favoured and $\mathrm{H}_{2}$ production should be avoided. Moreover, chapter 2 shows that, although $\mathrm{CO}_{2}$ could be the electrochemically active species, no net conversion of (the cathode side) gas phase is required. Therefore, $\mathrm{CO}_{2}$ is not consumed, but its presence can be used to optimize the reaction rate. As the goal is zero net hydrogen production, in the optimal case, hydrogen is neither produced nor consumed. Then, the gas phase is useful to influence reaction rates, but is not (net) converted in a continuous reactor at steady state.

An example of a reactor concept that utilizes $\mathrm{p}_{\mathrm{CO} 2}$ and $\mathrm{p}_{\mathrm{H} 2}$ to optimize rate is shown in Figure 4.7. At the cathode/catholyte side of the reactor, the gas phase is continuously recycled. (Alternatively, only a gas cap is also an option.) Consider the start-up of such a reactor, where the total pressure is allowed to increase freely. Initially only $\mathrm{CO}_{2}$ is present in the gas phase and the feed is pure $\mathrm{KHCO}_{3}$ solution. When a constant potential is applied, formate and hydrogen will form (reactions 4.1 and 4.2). As $\mathrm{CO}_{2}$ is not net consumed (Chapter 2), the $\mathrm{CO}_{2}$ partial pressure remains constant, but the hydrogen partial pressure will increase, thus increasing the total pressure. With increasing $\mathrm{p}_{\mathrm{H} 2}$, the rate of formate production remains constant (as observed in Figure 4.4), but hydrogen production decreases (as observed in Figure 4.3), thereby slowing a further increase in $\mathrm{p}_{\mathrm{H} 2}$. In the end, a steady state partial pressure of hydrogen is reached, where net hydrogen production is zero, thus selectivity towards 
formate $100 \%$. Depending on the absolute conditions, such a partial pressure of hydrogen can be as low as 4 bar (Figure 4.3). Therefore, a reactor concept, which recycles all produced hydrogen, may result in exclusive formate production, whilst the intrinsic selectivity of the catalyst is not $100 \%$. This is the electrochemical analogue of recycling the side product in an equilibrium reaction.

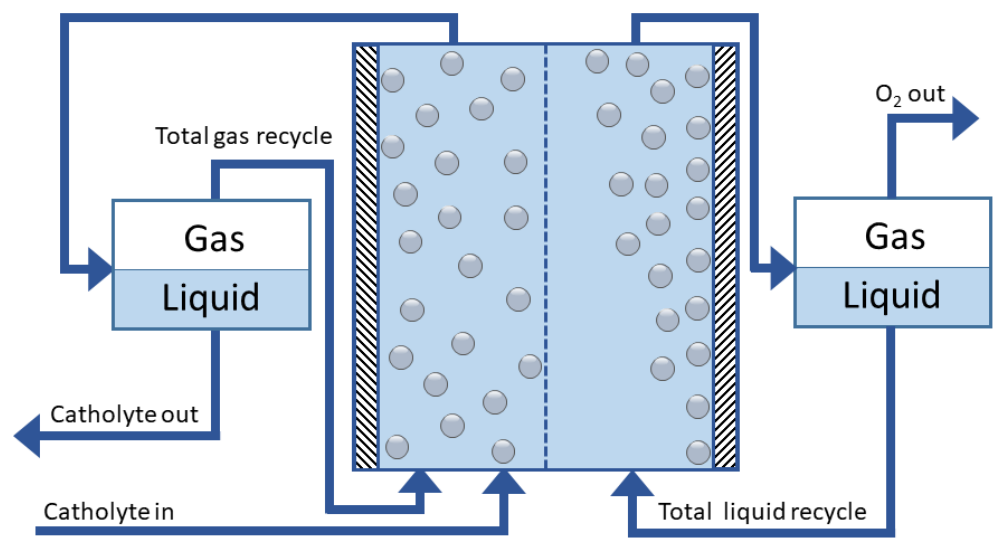

\section{Figure 4.6: Reactor concept for increasing selectivity to formate by recycling} gaseous hydrogen and $\mathrm{CO}_{2}$

For any given potential (the optimum being dependent on deactivation, regeneration, energy consumptions, etc) $\mathrm{p}_{\mathrm{CO} 2}$ can be optimised for maximum productivity and the $\mathrm{p}_{\mathrm{H} 2}$ corresponding to no net hydrogen evolution can be estimated or measured. For $-0.10 \mathrm{~V}$ vs RHE, a multitude of experimental data is available, hence that potential is considered (Figures 4.3-4.5). At -0.10V vs RHE, five bar of partial $\mathrm{CO}_{2}$ pressure is optimal for the rate to formate, but also causes significant hydrogen evolution (Figure 4.5), namely $\sim 120$ $\mu \mathrm{mol} / \mathrm{mg}_{\mathrm{Pd}} / \mathrm{s}$ formate and $\sim 80 \mu \mathrm{mol} / \mathrm{mg}_{\mathrm{Pd}} / \mathrm{s}$ hydrogen. Extrapolation based on Figure 4.3 , by taking an average slope of $5 \mu \mathrm{mol} / \mathrm{mg}_{\mathrm{Pd}} / \mathrm{s} / \mathrm{bar}_{\mathrm{H} 2}$ and assuming the linear trends continues, 16 bars of hydrogen pressure would be sufficient to eliminate net hydrogen evolution. Therefore, the system would reach an estimated steady state at a total pressure of 21 bar, where the cathodic gas phase composition is $25 \% \mathrm{CO}_{2}$ and $75 \%$ hydrogen. Modern electrolysers can operate at these pressures, making this a potentially viable concept. ${ }^{30}$

In a real application, some makeup of gas losses will always be necessary as dissolved gasses may migrate through the membrane or are evacuated with the liquid phase as dissolved gasses. The outgoing liquid phase should be degassed and any $\mathrm{CO}_{2}$ loss compensated. Hydrogen loss will be evident as Faraday Efficiency loss, but this will be very small due to the low solubility of hydrogen in water. Moreover, at higher formate concentrations (higher conversion of $\mathrm{KHCO}_{3}$ ), it is expected that the required hydrogen pressure increases due to equilibrium reaction 4.3. However, literature regarding only the chemical equilibrium shows that, at 10 bar $\mathrm{H}_{2}$ pressure, $>90 \%$ bicarbonate conversion can be reached, hence the effect is likely manageable. ${ }^{31}$ 


\subsection{Conclusion}

An electrochemical $\mathrm{CO}_{2}$ reduction cell that operates at elevated pressure and can still employ a cation exchange membrane and reference electrode was developed. Using this cell, it was shown that a presence of $\mathrm{H}_{2}$ in the gas phase suppresses hydrogen evolution on a $\mathrm{Pd} / \mathrm{C}$ catalyst. This novel approach provides an alternative to the common practice of increasing the selectivity by changing the catalyst structure or composition. Under electrochemical $\mathrm{CO}_{2}$ reduction conditions of 1 bar $\mathrm{CO}_{2}$ partial pressure and $-0.05 \mathrm{~V}$ vs RHE, 4 bar $\mathrm{H}_{2}$ pressure is sufficient to completely eliminate net $\mathrm{H}_{2}$ evolution, and a further increase to 6 bar results in net $\mathrm{H}_{2}$ consumption. Therefore, by allowing a natural accumulation of electrochemically produced hydrogen, either via gas cap or recycle, the selectivity to formate can be controlled. This opens the possibility to use other parameters ( $\mathrm{p}_{\mathrm{CO} 2}$, potential, temperature, etc.) to optimize the reaction rate, possibly creating the conditions for simultaneous high selectivity and conversion, as required for commercial implementation. 


\section{References}

1. Du, D., Lan, R., Humphreys, J. \& Tao, S. Progress in inorganic cathode catalysts for electrochemical conversion of carbon dioxide into formate or formic acid. J. Appl. Electrochem. 47, 661-678 (2017).

2. Díaz-Sainz, G. et al. CO2 electroreduction to formate: Continuous single-pass operation in a filter-press reactor at high current densities using Bi gas diffusion electrodes. J. CO2 Util. 34, 12-19 (2019).

3. Qiao, J., Liu, Y., Hong, F. \& Zhang, J. A review of catalysts for the electroreduction of carbon dioxide to produce low-carbon fuels. Chem. Soc. Rev. 43, (2014).

4. Bagger, A., Ju, W., Varela, A. S., Strasser, P. \& Rossmeisl, J. Electrochemical CO2 Reduction: A Classification Problem. ChemPhysChem 18, 3266-3273 (2017).

5. Benson, E. E., Kubiak, C. P., Sathrum, A. J. \& Smieja, J. M. Electrocatalytic and homogeneous approaches to conversion of $\mathrm{CO} 2$ to liquid fuels. Chem. Soc. Rev. 38, 89-99 (2009).

6. Zhu, D. D., Liu, J. L. \& Qiao, S. Z. Recent Advances in Inorganic Heterogeneous Electrocatalysts for Reduction of Carbon Dioxide. Adv. Mater. 28, 3423-3452 (2016).

7. Back, S., Kim, J.-H., Kim, Y.-T. \& Jung, Y. On the mechanism of high product selectivity for $\mathrm{HCOOH}$ using $\mathrm{Pb}$ in $\mathrm{CO} 2$ electroreduction. Phys. Chem. Chem. Phys. 18, 9652-9657 (2016).

8. Reda, T., Plugge, C. M., Abram, N. J. \& Hirst, J. Reversible interconversion of carbon dioxide and formate by an electroactive enzyme. Proc. Natl. Acad. Sci. U. S. A. 105, 10654-10658 (2008).

9. Min, X. \& Kanan, M. W. Pd-Catalyzed Electrohydrogenation of Carbon Dioxide to Formate: High Mass activity at Low Overpotential and Identification of the Deactivation Pathway. $J$. Am. Chem. Soc. 137, 4701-4708 (2015).

10. Sokol, K. P. et al. Reversible and Selective Interconversion of Hydrogen and Carbon Dioxide into Formate by a Semiartificial Formate Hydrogenlyase Mimic. J. Am. Chem. Soc. 141, 17498-17502 (2019).

11. Gao, D. et al. Switchable $\mathrm{CO} 2$ electroreduction via engineering active phases of $\mathrm{Pd}$ nanoparticles. Nano Res. 10, 2181-2191 (2017).

12. Sarkar, S. \& Peter, S. C. An overview on Pd-based electrocatalysts for the hydrogen evolution reaction. Inorg. Chem. Front. 5, 2060-2080 (2018).

13. Kortlever, R., Peters, I., Koper, S. \& Koper, M. T. M. Electrochemical CO2 Reduction to Formic Acid at Low Overpotential and with High Faradaic Efficiency on Carbon-Supported Bimetallic Pd-Pt Nanoparticles. ACS Catal. 5, 3916-3923 (2015).

14. Bai, X. et al. Exclusive Formation of Formic Acid from CO2 Electroreduction by a Tunable Pd-Sn Alloy. Angew. Chemie - Int. Ed. 56, 12219-12223 (2017).

15. Jiang, B., Zhang, X. G., Jiang, K., Wu, D. Y. \& Cai, W. Bin. Boosting Formate Production in Electrocatalytic CO2 Reduction over Wide Potential Window on Pd Surfaces. J. Am. Chem. Soc. 140, 2880-2889 (2018).

16. Zhou, F., Li, H., Fournier, M. \& MacFarlane, D. R. Electrocatalytic CO2Reduction to Formate at Low Overpotentials on Electrodeposited Pd Films: Stabilized Performance by Suppression of CO Formation. ChemSusChem 10, 1509-1516 (2017).

17. Klinkova, A. et al. Rational Design of Efficient Palladium Catalysts for Electroreduction of Carbon Dioxide to Formate. ACS Catal. 6, 8115-8120 (2016). 
18. Su, J., Yang, L., Lu, M. \& Lin, H. Highly efficient hydrogen storage system based on ammonium bicarbonate/formate redox equilibrium over palladium nanocatalysts. ChemSusChem 8, 813-816 (2015).

19. Engel, D. C., Versteeg, G. F. \& Van Swaaij, W. P. M. Reaction kinetics of hydrogen and aqueous sodium and potassium bicarbonate catalysed by palladium on activated carbon. Chemical Engineering Research and Design 73, 701-706 (1995).

20. Yang, W., Dastafkan, K., Jia, C. \& Zhao, C. Design of Electrocatalysts and Electrochemical Cells for Carbon Dioxide Reduction Reactions. Adv. Mater. Technol. 3, 1-20 (2018).

21. Liang, S., Altaf, N., Huang, L., Gao, Y. \& Wang, Q. Electrolytic cell design for electrochemical CO2 reduction. J. CO2 Util. 35, 90-105 (2019).

22. Lobaccaro, P. et al. Effects of temperature and gas-liquid mass transfer on the operation of small electrochemical cells for the quantitative evaluation of $\mathrm{CO}_{2}$ reduction electrocatalysts. Phys. Chem. Chem. Phys. 18, 26777-26785 (2016).

23. Cai, F. et al. Electrochemical promotion of catalysis over Pd nanoparticles for $\mathrm{CO}_{2}$ reduction. Chem. Sci. (2017). doi:10.1039/C6SC04966D

24. Wu, S. Y. \& Chen, H. T. CO2 Electrochemical Reduction Catalyzed by Graphene Supported Palladium Cluster: A Computational Guideline. ACS Appl. Energy Mater. 2, 1544-1552 (2019).

25. Lasia, A. Mechanism and kinetics of the hydrogen evolution reaction. Int. J. Hydrogen Energy 44, 19484-19518 (2019).

26. Cave, E. R. et al. Electrochemical $\mathrm{CO}_{2}$ reduction on Au surfaces: mechanistic aspects regarding the formation of major and minor products. Phys. Chem. Chem. Phys. 19, 1585615863 (2017).

27. Kas, R., Kortlever, R., Yilmaz, H., Koper, M. T. M. \& Mul, G. Manipulating the Hydrocarbon Selectivity of Copper Nanoparticles in $\mathrm{CO} 2$ Electroreduction by Process Conditions. ChemElectroChem 2, 354-358 (2015).

28. Singh, M. R., Clark, E. L. \& Bell, A. T. Effects of electrolyte, catalyst, and membrane composition and operating conditions on the performance of solar-driven electrochemical reduction of carbon dioxide. Phys. Chem. Chem. Phys. 17, 18924-18936 (2015).

29. Durst, J. et al. Electrochemical CO\&lt;SUB\&gt;2\&lt;/SUB\&gt; Reduction - A Critical View on Fundamentals, Materials and Applications. Chim. Int. J. Chem. 69, 769-776 (2015).

30. Grigoriev, S. A., Fateev, V. N., Bessarabov, D. G. \& Millet, P. Current status, research trends, and challenges in water electrolysis science and technology. Int. J. Hydrogen Energy 45, 26036-26058 (2020).

31. Engel, D. C., Versteeg, G. F. \& van Swaaij, W. P. M. Chemical equilibrium of hydrogen and aqueous solutions of 1:1 bicarbonate and formate salts with a common cation. Fluid Phase Equilib. 135, 109-136 (1997). 


\section{Appendix}

\section{A4.1 Error analysis and statistics}

$\mathrm{Pd} / \mathrm{C}$ electrodes are known to deactivate under electrochemical $\mathrm{CO}_{2}$ reduction conditions. This deactivation is mostly reversible, with the exception of a small initial deactivation. Therefore, the electrode was first used in a standard experiment and the accompanying data was omitted. Between experiments, the electrode was regenerated by 30 s anodic polarization at $1.3 \mathrm{~V}$ vs RHE. That resulted in reproducible results, as shown in Figure A4.1. The standard deviation over the faraday efficiency is 2.7 percent point.

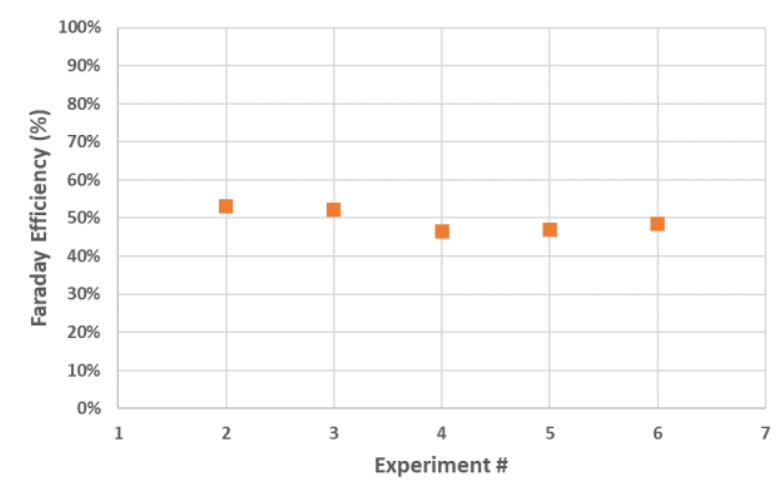

Figure A4.1: Repeatability assessment of $\mathrm{Pd} / \mathrm{C}$ electrode for $\mathrm{CO}_{2}$ reduction in $1 \mathrm{M} \mathrm{KHCO}$ at 1 bar.

Based on the repeatability experiments a $95 \%$ confidence interval was calculated. For other measurements, an estimate of the error was made based on that value. The $95 \%$ confidence interval values for the rate to $\mathrm{H}_{2}$ and rate to $\mathrm{HCOO}^{-}$in the repeatability experiment were scaled linearly to the measured value in other experiments. Regular data points are thus measured only once, and the error in their value is estimated based on the outcome of the repeatability experiments. This method is chosen as differences between electrodes are large and electrodes can break after several experiments. In this way, one electrode can be used per trend and an estimate of the error is provided.

An F-test analysis was performed to determine whether the trends in Figure 4.3 and Figure 4.4 are best described based on the sample mean, a linear equation $(\mathrm{ax}+\mathrm{b})$ or a second order polynomial $\left(a x^{2}+b x+c\right)$. For Figure 4.3 (rate to $\mathrm{H}_{2}$ as function of $\mathrm{p}_{\mathrm{H} 2}$ ) it was found that a linear two-parameter description gave a significantly better fit than the sample mean $(99.5 \%$ confidence), but that a second order polynomial did not significantly improve the fit. For Figure 4.4 (rate to $\mathrm{HCOO}^{-}$as function of $\mathrm{p}_{\mathrm{H}}$ ) a linear equation did not give a significantly better fit than the sample mean. 


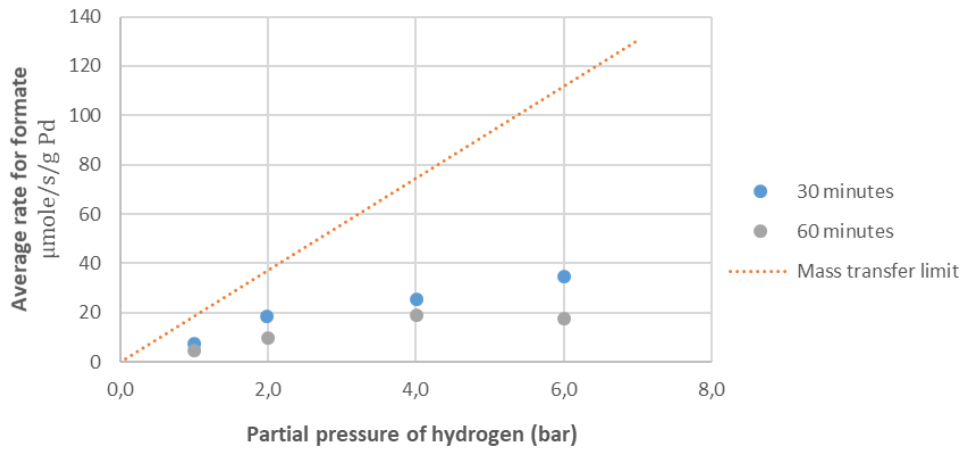

Figure A4.2: Measurement of hydrogenation rate to formate in $\mathrm{1M}^{\mathrm{KHCO}} 3$ in the absence of potential. Mass transfer limit measured by electrochemical oxidation of $\mathbf{H}_{2}$.

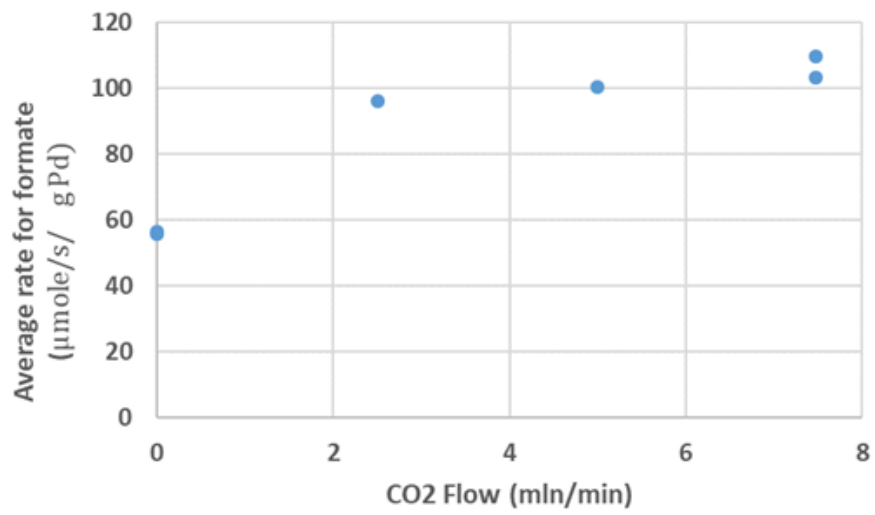

Figure A4.3: Variation of $\mathrm{CO}_{2}$ flow at 1 bar to asses effects of mass transfer 
Table A4.1: Calculated equilibrium composition of catholyte, for pco2 $=1$ bar and $\operatorname{pco}_{\mathrm{CO}}=3$ bar via calculations described in appendix A2.2.

\begin{tabular}{lll}
\hline $\mathrm{PCO} 2($ bar $)$ & 1 & 3 \\
\hline $\mathrm{pH}(-)$ & 7.82 & 7.34 \\
{$\left[\mathrm{H}^{+}\right](\mathrm{mole} / \mathrm{L})$} & $1.52 \cdot 10^{-8}$ & $4.54 \cdot 10^{-8}$ \\
{$\left[\mathrm{CO}_{2}\right](\mathrm{mole} / \mathrm{L})$} & 0.034 & 0.102 \\
{$\left[\mathrm{HCO}^{-}\right](\mathrm{mole} / \mathrm{L})$} & 0.99 & 1.00 \\
{$\left[\mathrm{CO}_{3}{ }^{-}\right](\mathrm{mole} / \mathrm{L})$} & 0.00 & 0.00 \\
\hline
\end{tabular}





\section{Chapter 5}

\section{Mechansim for $\mathrm{CO}_{2}$ reduction on $\mathrm{Pd} / \mathrm{C}$}

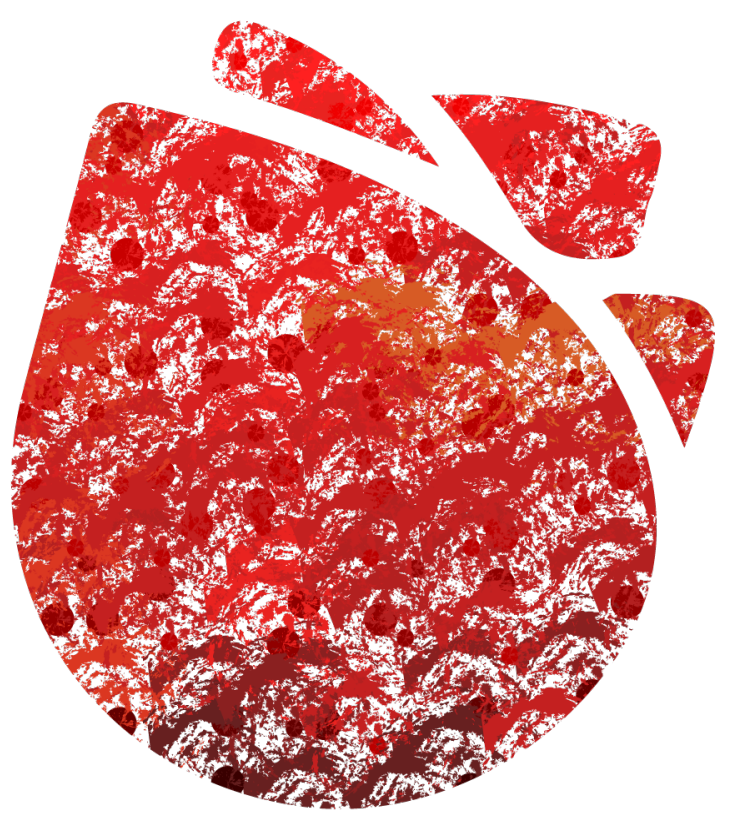

'If people do not believe that mathematics is simple, it is only because they do not realize how complicated life is'

- John von Neumann - 


\begin{abstract}
In this chapter, the mechanism for electrochemical reduction of $\mathrm{CO}_{2}$ to formate on $\mathrm{Pd} / \mathrm{C}$ is researched. From the kinetic data in Chapter 4, trends in rates of formation of $\mathrm{HCOO}^{-}$and $\mathrm{H}_{2}$ as function of several parameters ( $\mathrm{p}_{\mathrm{H} 2}, \mathrm{p}_{\mathrm{CO} 2}$ and potential) are isolated and compared to model descriptions based on several proposed mechanisms. Proposed mechanisms that under no circumstance can describe the observed trends are dismissed. An $\alpha / \beta$-hydride mechanism, based on an $\alpha$-hydride phase active for $\mathrm{CO}_{2}$ reduction and $\beta$-hydride Pd-phase active for hydrogen evolution, described experimental data of our and other laboratories reported in the literature satisfactorily. After parametrization, using a data set including only $\mathrm{H}_{2}$, this mechanism also predicted the outcome of $\mathrm{D}_{2}$ isotope labelling experiments correctly. Analyses of the results indicates the $\alpha / \beta$-hydride ratio and hydride formation rate are key factors affecting the formate production rate and the selectivity, thereby identifying areas for further (spectroscopic) studies and mechanism validation.
\end{abstract}

This chapter is published as Blom, M.J.W., van Swaaij, W.P.M., Mul, G. \& Kersten, S.R.A Mechanism and Micro Kinetic Model for Electroreduction of CO2 on Pd/C: The Role of Different Palladium Hydride Phases ACS Catalysis $2021,11,12,6883-6891$ 


\begin{tabular}{ll} 
Nomenclature & \\
\hline Symbol & Description [unit] \\
\hline $\mathrm{A}^{z}$ & Anion with charge z \\
$c_{i}$ & Concentration of species i [mole/L] \\
$c_{i}^{S}$ & Surface concentration of species i [mole/dm $\left.{ }^{2}\right]$ \\
$E$ & Applied potential [V vs RHE] \\
$E_{n}^{e q}$ & Equilibrium potential for reaction $\mathrm{n}[\mathrm{V}$ vs RHE] \\
$F$ & Faraday constant [s A/mole] \\
$k_{n}$ & Rate constant for reaction n \\
$\mathrm{KIE}$ & Kinetic isotope effect rate factor $[-]$ \\
$p_{i}$ & Partial pressure of species i [bar] \\
$r_{n}$ & Rate of reaction $\mathrm{n}[\mu \mathrm{mol} / \mathrm{s} / \mathrm{g}$ Pd] \\
$R$ & Gas constant [J/K/mole] \\
$T$ & Temperature [K] \\
$\mathrm{z}$ & Charge number [-] \\
$\alpha_{n}$ & Charge transfer coefficient for reaction $\mathrm{n}[-]$ \\
$\theta_{i}$ & Fractional occupancy of sites with species i [-] \\
\hline
\end{tabular}

\subsection{Introduction}

A multitude of studies regarding electrochemical $\mathrm{CO}_{2}$ reduction on various catalysts has yielded, amongst others, the discovery of novel catalytic materials, increasing current densities and identification of tens of parameters that influence reaction rates. ${ }^{1-3}$ Despite significant efforts and some advances, the reaction mechanisms at play for various electrocatalysts are still uncertain., ${ }^{4,5}$ More insights into these reaction mechanisms is highly desired as this insight can guide catalyst development and allow rational kinetic modelling and therewith reactor design. $3,5,6$

Palladium based electrocatalysts have received relatively little attention, even though $\mathrm{Pd}$ requires exceptionally low overpotentials towards electrochemical reduction of $\mathrm{CO}_{2} .{ }^{7}$ Even at $0.00 \mathrm{~V}$ vs RHE, $\mathrm{Pd} / \mathrm{C}$ produces formate with hydrogen as only side product $(0$ to $-0.20 \mathrm{~V}$ vs RHE). ${ }^{7,8}$ Furthermore, the mechanism of Pd (supported on C) electrodes in converting $\mathrm{CO}_{2}$ to formate is particularly intriguing, since electrocatalytic reduction (reaction 5.1), and catalytic hydrogenation of $\mathrm{CO}_{2}$ to formate (reaction 5.3) occur simultaneously, while also the undesired hydrogen evolution (reaction 5.2) takes place. ${ }^{9}$ When a potential between 0.0 and $-0.20 \mathrm{~V}$ vs RHE is applied, reactions 1 and 2 both occur. ${ }^{7,8}$ In a pressure range of $0-10$ bar of hydrogen, the equilibrium composition of catalytic reaction 3 is dependent on the hydrogen pressure. $^{10}$ 


$$
\begin{aligned}
& \mathrm{CO}_{2}+\mathrm{HA}^{z+1}+2 e^{-} \rightleftarrows \mathrm{HCOO}^{-}+A^{z} \\
& 2 \mathrm{HA}^{z+1}+2 e^{-} \rightleftarrows \mathrm{H}_{2}+2 A^{z} \\
& \mathrm{CO}_{2}+\mathrm{H}_{2}+A^{z} \rightleftarrows \mathrm{HCOO}^{-}+\mathrm{HA}^{z+1}
\end{aligned}
$$

Interestingly, in chapter 4 , it was found experimentally that hydrogen formation could be prevented by increasing the partial hydrogen pressure, ${ }^{11}$ an effect that occurred well below the equilibrium pressure of $\mathrm{H}_{2}$ (reaction 5.2) as calculated via Nernst's Law. No significant changes in the rate to formate were observed and consequently current decreased as function of the partial pressure of hydrogen. Simultaneously, others reported data that showed different trends: an increased formate production rate and increased current as a function of increasing partial pressure of hydrogen. ${ }^{12,13}$

Reported values for rate and selectivity on $\mathrm{Pd} / \mathrm{C}$ catalysed reduction of $\mathrm{CO}_{2}$ can vary significantly between sources. E.g. on $\mathrm{Pd} / \mathrm{C}$ catalysts, reported Faradaic efficiencies towards formate at -0.20 vs RHE vary from $10 \%$ to $98 \%$ 7,14,15. This issue is not limited to $\mathrm{Pd} / \mathrm{C}$ but is a common problem in electrochemical processes, due to multistep procedures for catalyst and electrode preparation and the high sensitivity of electrochemistry towards minor impurities. ${ }^{16}$ Preparing Pd/C electrodes introduces a multitude of variables including: (i) The type of $\mathrm{Pd} / \mathrm{C}$ catalyst used, (ii) composition of the catalyst ink, (iii) application procedure of the catalyst ink, (iv) drying procedure of the catalyst ink, and so on and so forth. ${ }^{17-21}$ With strict preparation procedures, we were able to minimise the effect of these variables (Chapter 4 and Figure A5.1). Trends in reaction rates were consistent between electrodes, while variations in absolute values of reaction rates between electrodes were still observed. Through data normalization per electrode, trends were isolated, which provided the handle for evaluating the reaction mechanism.

The majority of mechanistic insight regarding electrochemical reduction of carbon dioxide is obtained through density functional theory (DFT) simulations and/or measurements of the Tafel slope. ${ }^{4,5}$ Those valuable results have led to significant advances, but they oftentimes require additional experimental proof to be fully validated. ${ }^{5,22}$ Operando spectroscopic observations of reaction intermediates and concentration transients at interfaces have contributed to understanding the effect of surface modifications of electrodes on performance, but conclusions regarding mechanisms on the bases of these methodologies need to be drawn with caution. ${ }^{23-25}$

Here the mechanism of electrochemical conversion of $\mathrm{CO}_{2}$ over $\mathrm{Pd} / \mathrm{C}$ electrodes is studies by comparing trends in observed reaction rates with postulated meachnisms, a method widely practised in reaction engineering (of catalytic reactions) and applicable without specialised equipment. ${ }^{26}$ This method comprises of: i) postulating plausible reaction mechanisms based on (literature) observations and theory, ii) kinetic modelling of those mechanisms including parameterization iii) comparison of experimentally observed trends with description of these trends by the parameterized models. The latter step identifies invalid mechanisms as those that cannot describe (all) the measured trends. 
Intrinsic to the method, parameterization of the models yields a set of many cross-correlated parameters. This a consequence of the fact that intermediate species are not experimentally quantified. However, the exact set of parameter values is irrelevant, as the criterion for dismissal of a mechanism is an inability to describe the trends. Moreover, with adequate measurements of intermediate species and products, cross-correlations can be resolved. The method can dismiss incorrect mechanisms in an early stage. Therefore, research efforts can be efficiently focused, streamlining the research process.

\subsection{Experimental}

Measurement procedures and results are detailed in chapter 4. During isotopically labelled experiments, the gas outlet of the catholyte was connected to a mass spectrometer (MS) for analysis of the gas phase. To measure trends in the most consistent manner, all data points that describe a trend (a single line in a graph) were evaluated with the same electrode, in random order. All graphs have been normalised. The rates were measured experimentally and normalised against a data point for the rate to formate. Model results were normalised against the modelled rate to formate at corresponding conditions. The specific conditions for normalisation are described in the figure captions, but these do not affect results. By normalising, the effect of variations between electrodes is minimised, but remains significant.

\section{Isotopic labelling of gas phase}

Gas phase hydrogen was labelled with deuterium $\left(\mathrm{D}_{2}\right)$, whereas the liquid phase (water) was not. Therefore, in the presence of exogenous $\mathrm{D}_{2}$, the production rates of $\mathrm{H}_{2}$ and $\mathrm{HD}$ can be monitored by mass spectroscopy (MS). All protium atoms $(\mathrm{H})$ then originate from the liquid phase, either via electro-reduction or isotope exchange ${ }^{39}$ (Reaction 5.4). Regardless of the origin of $\mathrm{H}$, the rates of $\mathrm{H}_{2}$ and $\mathrm{HD}$ can be used to estimate the relative abundance of $\mathrm{H}$ and $\mathrm{D}$ at the Pd surface, which is active for hydrogen evolution (equation 5.5) and the magnitude of $r_{3}$ (equation 5.6). See appendix section A5.1 for a full derivation.

$\mathrm{H}_{2} \mathrm{O}+\mathrm{PdD} \rightarrow \mathrm{PdH}+\mathrm{HDO}$

$\frac{C_{H}^{S}}{C_{D}^{S}}=\frac{2 r_{H 2}}{r_{H D}} \frac{1}{K I E}$

$r_{3}=r_{H 2}+r_{H D}+\frac{\left(r_{H D}\right)^{2}}{4 r_{H 2}}$

The cell and solution were prepared as normal. After connecting the cell, the gas phase was continuously analysed by MS. First the outlet gas phase was analysed without applied potential. When the MS signals had stabilised, potential was applied. The experiment was continued until MS signals had stabilised again. The stabilised signals were a semi-steady state and used in further calculations.

\section{Error analysis}

The error bars that are indicated in Figures 5.3A and 5.3B are based on fluctuations in the MS signal and level of baseline noise. It constitutes to $5 \%$ of the signal strength plus a 
baseline factor (1E-10 A). From total error in the signal, the maximum error in the calculated $\mathrm{H} / \mathrm{D}$ fractions and rate of $r_{3}$ was calculated. Based on equation 5.6, the error in $r_{3}$ grows to very large values, for low $\mathrm{H}_{2}$ signals in the MS.

\subsection{Results and discussion}
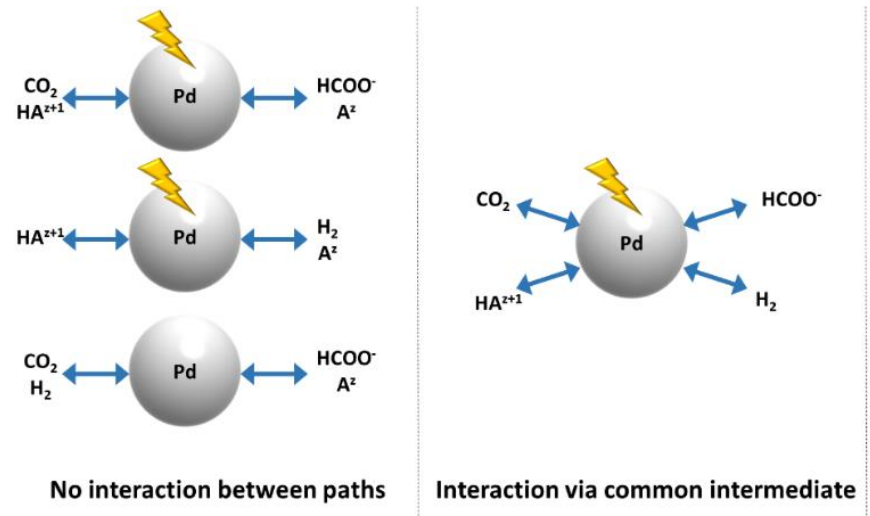

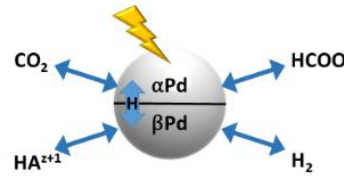

Interaction via distinct intermediates

\section{Figure 5.1: Representation of three classes of reaction schemes}

Various reaction mechanisms were conceived in this chapter and sorted in three classes (see Figure 5.1), based on interaction between reaction paths. The first class consists of mechanisms with no interaction between reactions 5.1-5.3 through adsorbed intermediates. This means that all reactions can be described with independent rate equations (left graph, Figure 5.1). In the second class of mechanisms, all reaction paths share one common adsorbed intermediate $(\mathrm{Pd}-\mathrm{H})$. In the last class, formate and hydrogen production do not occur via a common adsorbed intermediate, but occur on two different phases of Pd (the $\alpha$ and $\beta$-phases, giving $\alpha \mathrm{Pd}-\mathrm{H}$ and $\beta \mathrm{pd}-\mathrm{H}$ intermediates). Within a class, the trends described by the three models (increasing, decreasing or constant) are summarized in Table 5.1 and compared to experimental trends. Note that a decrease in E corresponds to a more negative potential, thus increased driving force for the cathodic electrochemical reactions. Hereunder a more detailed description of each class and model follows, with a specific focus on the effect of $\mathrm{p}_{\mathrm{H} 2}$ on $\mathrm{r}_{\mathrm{HCOO}}$ and $\mathrm{r}_{\mathrm{H} 2}$, namely a decrease in $\mathrm{r}_{\mathrm{H} 2}$ without a change in $\mathrm{r}_{\mathrm{HCOO}}$ - when $\mathrm{p}_{\mathrm{H} 2}$ is increased. 
Table 5.1: Experimental trends and trends as described by the various reaction schemes. Arrows and dash denote upward, downward or no trend. Green indicates correct model description and red indicates incorrect model description. The table shows the model description that yielded the highest amount of trends described correctly.

\begin{tabular}{lccccccc}
\hline $\begin{array}{l}\text { Trend in } \\
\text { As function of }\end{array}$ & $\begin{array}{c}\mathrm{r}_{\mathrm{HCOO}} \\
\left(\mathrm{p}_{\mathrm{H} 2} \uparrow\right)\end{array}$ & $\begin{array}{c}\mathrm{r}_{\mathrm{H} 2} \\
\left(\mathrm{p}_{\mathrm{H} 2} \uparrow\right)\end{array}$ & $\begin{array}{c}-\mathrm{I} \\
\left(\mathrm{p}_{\mathrm{H} 2} \uparrow\right)\end{array}$ & $\begin{array}{c}\mathrm{r}_{\mathrm{HCOO}-} \\
\left(\mathrm{p}_{\mathrm{CO} 2} \uparrow\right)\end{array}$ & $\begin{array}{c}\mathrm{r}_{\mathrm{H} 2} \\
\left(\mathrm{p}_{\mathrm{CO} 2} \uparrow\right)\end{array}$ & $\begin{array}{c}\mathrm{r}_{\mathrm{HCOO}}- \\
(\mathrm{E} \downarrow)\end{array}$ & $\begin{array}{c}\mathrm{r}_{\mathrm{H} 2} \\
(\mathrm{E} \downarrow)\end{array}$ \\
\hline $\begin{array}{l}\text { Experimental } \\
\text { No interaction models }\end{array}$ & - & $\downarrow$ & $\downarrow$ & $\uparrow$ & $\uparrow$ & $\uparrow$ & $\uparrow$ \\
$\begin{array}{l}\text { Common intermediate } \\
\text { models }\end{array}$ & $\uparrow$ & $\downarrow$ & $\downarrow$ & $\uparrow$ & $\downarrow$ & $\uparrow$ & $\uparrow$ \\
$\alpha / \beta$-hydride model & - & $\downarrow$ & $\downarrow$ & $\uparrow$ & $\uparrow$ & $\uparrow$ & $\uparrow$ \\
\hline
\end{tabular}

\section{Mechanisms based on fully separate reaction paths}

Mechanisms that have fully separated paths are potentially the simplest. They share the basic assumption that all reactions occur in parallel, without interaction between intermediates. Such mechanisms could occur when only part of the catalyst is electrochemically active, due to lack of electrical contact or when different active sites are involved in each reaction. Regardless of the exact mechanism, without a common intermediate, there are two possibilities via which an increasing $\mathrm{p}_{\mathrm{H} 2}$ results in a decrease in $\mathrm{r}_{\mathrm{H} 2}$. Either when it promotes hydrogen consumption for hydrogenation of $\mathrm{CO}_{2}$ to formate (reaction 5.3) or when it suppresses hydrogen evolution (reaction 5.2). The former must be accompanied by increasing formate production, given the stoichiometry of reaction 3, which is not observed. Suppression of reaction 2 would result in a decrease of $\mathrm{r}_{\mathrm{H} 2}$ as function of $\mathrm{p}_{\mathrm{H} 2}$, whilst keeping $\mathrm{r}_{\mathrm{HCOO}}$ constant. However, thermodynamic calculations show that 49 bar hydrogen pressure is needed to suppress hydrogen evolution at the experimental conditions, whereas measurements show that 4 bar is sufficient (Figure 5.2A). Additionally, in the absence of $\mathrm{CO}_{2}$ and bicarbonate, no significant effect of the hydrogen pressure on the current is observed between 0 and 6 bar (Figure A5.2). Consequently, given only reactions 5.1-5.3, there should be at least some form of interaction between reaction intermediates to explain the experimental trends.

\section{Mechanisms with a common intermediate}

Palladium is known to easily form palladium hydride $\left(\mathrm{Pd}-\mathrm{H}_{\mathrm{x}} 0<\mathrm{x}<1\right)$ in aqueous solution, when the cathodic potential is applied or the metal is contacted with (dissolved) hydrogen. ${ }^{27,28}$ Recent insight suggests that also electrochemical reduction of $\mathrm{CO}_{2}$ occurs over a palladium hydride phase. ${ }^{7,8}$ Therefore, hydride could be a common intermediate, coupling both reaction paths, shown as Scheme 5.1. 
The reaction mechanism in Scheme 5.1 can exhibit various responses of $\mathrm{r}_{\mathrm{Hcoo}}$ and $\mathrm{r}_{\mathrm{H} 2}$ to $\mathrm{p}_{\mathrm{H} 2}$ and $\mathrm{p}_{\mathrm{CO} 2}$, depending on how $\mathrm{CO}_{2}$ is adsorbed (either on the $\mathrm{Pd}$ atom or reactively with the $\mathrm{H}$ of $\mathrm{Pd}-\mathrm{H}$ ) and how hydrogen evolution occurs (via the Heyrovsky or Tafel reaction). In general, we can state that when $\mathrm{r}_{\mathrm{H} 2}$ decreases as function of $\mathrm{p}_{\mathrm{H} 2}$, the $\mathrm{HA}^{\mathrm{z}+1}$ reduction rate must decrease and/or $\mathrm{r}_{\mathrm{HCOO}}$ must increase, to maintain a quasi-steady state occupation of Pd sites. Measurements show constant $\mathrm{r}_{\mathrm{HCOO}}$ - with varying $\mathrm{p}_{\mathrm{H} 2}$. Therefore, the $\mathrm{HA}^{\mathrm{z+1}}$ reduction rate must decrease. However, as evident from scheme 5.1, that requires a change in the $\mathrm{Pd}-\mathrm{H}$ coverage of the surface, which in turn would affect $\mathrm{r}_{\mathrm{HCOO}}$. In scheme 5.1 , with $\mathrm{Pd}-\mathrm{H}$ as common intermediate, no single reaction can be influenced independently of the others. Therefore, we need to consider a mechanism with distinct intermediates for each product that however does incorporate interaction between those intermediates.

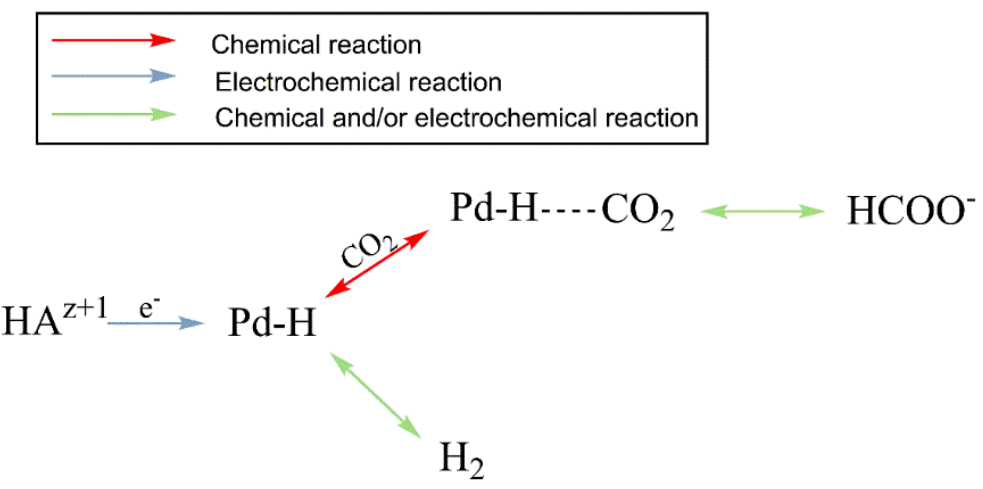

\section{Scheme 5.1: Reaction mechanism with palladium hydride as common intermediate}

\section{The $\alpha / \beta$-hydride mechanism}

Palladium is a unique metal in hydrogenation chemistry. Whilst all platinum group metals readily adsorb hydrogen onto their surface, palladium also forms a bulk hydride that includes a relatively large amount of hydrogen atoms. Those atoms are mobile within the palladium and even led to the development of metal membranes for hydrogen purification. ${ }^{29,30}$ Within a palladium (nano)particle the hydride can move over the surface as well as through the bulk. ${ }^{30,31}$ We hypothesise that this mobility of $\mathrm{H}$ within a Pd particle is key in understanding the observed behaviours in electrochemical applications. The mobility of the hydride allows different active sites to interact.

In the presence of hydrogen or under cathodic potential in water, palladium shows at least two distinct hydride phases. ${ }^{8,27} \alpha$-hydride, in which hydrogen is covalently bound to palladium in the ratio $\mathrm{Pd}-\mathrm{H}_{\mathrm{x}}(\mathrm{x}<0.03$ at $303 \mathrm{~K})$ and $\beta$-hydride, in which hydrogen forms metallic bonds with palladium in the ratio $\mathrm{Pd}-\mathrm{H}_{\mathrm{y}}(\mathrm{y}>0.6) .{ }^{32}$ Depending on the conditions, both hydride phases may coexist. ${ }^{8,32}$ Research on electrochemical reduction of $\mathrm{CO}_{2}$ revealed, 
based on in situ X-ray absorption spectroscopy and in situ attenuated total reflection-infrared spectroscopy, that formate was only formed when $\alpha$-hydride was present, whereas hydrogen could also be formed on $\beta$-hydride. ${ }^{8}$ In fact, hydrogen production was most significant when high $\beta$-hydride fractions were present. ${ }^{8}$
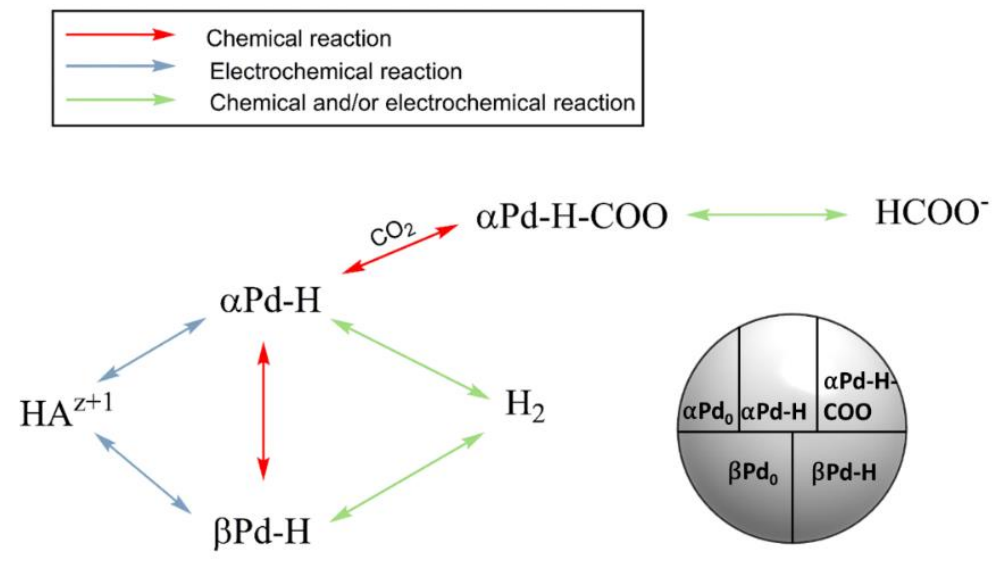

\section{Scheme 5.2: Reaction mechanism for the $\alpha / \beta$-hydride model. Pd surface species shown on the right-hand side.}

Scheme 5.2 incorporates both hydride phases into a mechanism where formate is exclusively formed over the $\alpha \mathrm{Pd}$ sites and hydrogen transfer between $\alpha \mathrm{Pd}$ and $\beta \mathrm{Pd}$ sites is feasible, which is in agreement with the aforementioned spectroscopic observations. Pd is considered to have two types of sites, $\alpha$-sites and $\beta$-sites. The $\alpha$-sites can be either empty $\left(\alpha \mathrm{Pd}_{0}\right)$, contain a hydrogen atom $(\alpha \mathrm{Pd}-\mathrm{H})$ or contain a hydrogen $+\mathrm{CO}_{2}$ intermediate $(\alpha \mathrm{Pd}-\mathrm{H}-\mathrm{COO})$, whereas the $\beta$-sites can be empty $\left(\beta \mathrm{Pd}_{0}\right)$ or contain hydrogen $(\beta \mathrm{Pd}-\mathrm{H})$. Scheme 5.2 considers all possible reactions that can reasonably occur in the reversible system. Hereunder Scheme 5.3 demonstrates the simplification of scheme 5.2 to aid modelling, and corresponding equations and data fitting are described in the appendix.

We consider the scheme under electrochemical $\mathrm{CO}_{2}$ reduction conditions. Given the mobility of the hydrogen atoms in palladium, fast exchange of $\mathrm{H}$ between $\alpha$ - and $\beta$-sites is likely. Moreover, there is much more $\beta$-hydride than $\alpha$-hydride. Hence, it is assumed that all hydrogen formation originates from $\beta$-hydride and that all $\mathrm{HA}^{\mathrm{z}+1}$ is reduced to $\beta$-hydride and vice versa. Given the electrochemical conditions and low formate concentration in experiments, we assume that formate is produced by irreversible electrochemical reduction of the adsorbed $\mathrm{CO}_{2}$ intermediate. Lastly, we assume that hydrogen evolution only occurs via combination of two hydrogen atoms (Tafel step), which is in agreement with literature at mild cathodic potential. ${ }^{33-36}$ 


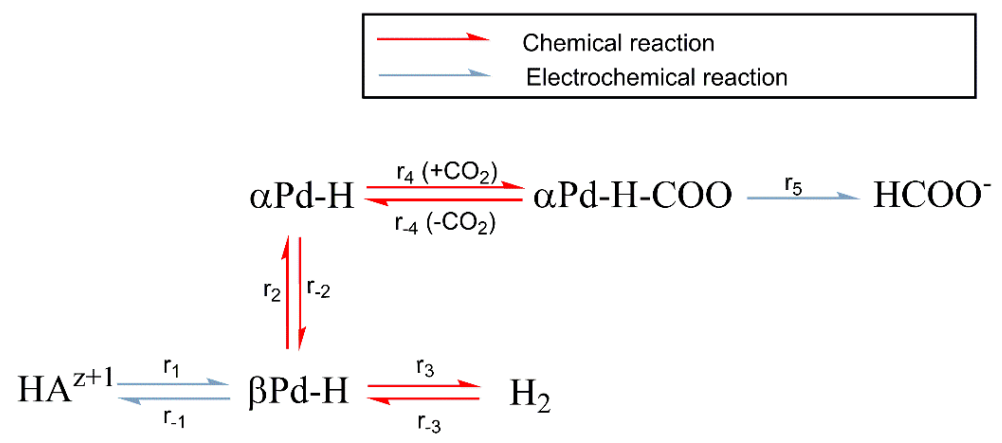

\section{Scheme 5.3: Simplification of Scheme 2, by only considering the most important reactions.}

Table 5.1 shows the modelled trends versus experimentally observed trends. Current as function of $\mathrm{p}_{\mathrm{H} 2}$ is included in Table 5.1. Current and rates to $\mathrm{H}_{2}$ and $\mathrm{HCOO}^{-}$are related via $I \propto r_{\mathrm{HCOO}-}+r_{\mathrm{H} 2}$, hence current provides additional information when trends in $\mathrm{r}_{\mathrm{HCOO}}$ and $\mathrm{r}_{\mathrm{H} 2}$ oppose each other. Table 5.1 demonstrates that the $\alpha / \beta$-hydride model can correctly describe all trends. Figure 5.2 provides more detail, showing that despite variations inherent to electrode preparation, a simple model can correctly describe trends in a convoluted electrochemical reaction system.

Figure 5.2A shows that the model can correctly describe constant $\mathrm{r}_{\mathrm{HCOO}}$ - versus $\mathrm{p}_{\mathrm{H} 2}$. The trend is explained by a constant loading of the $\alpha$-hydride phase, which does not change with $\mathrm{p}_{\mathrm{H} 2}$ (Figure 5.2D). The model also describes $\mathrm{r}_{\mathrm{H} 2}$ decreasing with $\mathrm{p}_{\mathrm{H} 2}$, which is a result of increased $r_{-3}$ (Scheme 5.3). With $r_{-3}$, the $\beta$-hydride loading rises and in turn, $r_{3}$ increases and $r_{1}$ decreases. To a minor extent, $\mathrm{r}_{-1}$ also increases. The net effect is reduced hydrogen evolution with increasing $\mathrm{p}_{\mathrm{H} 2}$. Note that this does not go against thermodynamics, as electrochemical hydrogen/hydride oxidation does not occur significantly. The suppression of $\mathrm{r}_{\mathrm{H} 2}$ is caused by hindering proton reduction $\left(\mathrm{r}_{1}\right)$ due to an increased $\beta$-hydride loading on the surface.

The trends in Figure 5.2B again show that the model is correct in describing an increase in $\mathrm{r}_{\mathrm{HCOO}}$ and $\mathrm{r}_{\mathrm{H} 2}$ with increasing $\mathrm{p}_{\mathrm{CO} 2}$. For $\mathrm{r}_{\mathrm{HCOO}}$ the rise is a result of an increased loading of adsorbed $\mathrm{CO}_{2}$ via $\mathrm{r}_{4}$ (Figure $2 \mathrm{E}$ ), which is in agreement with the reaction scheme proposed by Min and Kanan. ${ }^{7}$ The effect of $\mathrm{p}_{\mathrm{CO} 2}$ on $\mathrm{r}_{\mathrm{H} 2}$ occurs indirectly, as the solution $\mathrm{pH}$ drops due to the acidic nature of dissolved $\mathrm{CO}_{2}$. Therefore, $\mathrm{r}_{1}$ increases due to increased $\mathrm{c}_{\mathrm{H}+}$ (equation 5.4), which raises the $\beta \mathrm{Pd}-\mathrm{H}$ loading and increases hydrogen evolution. 

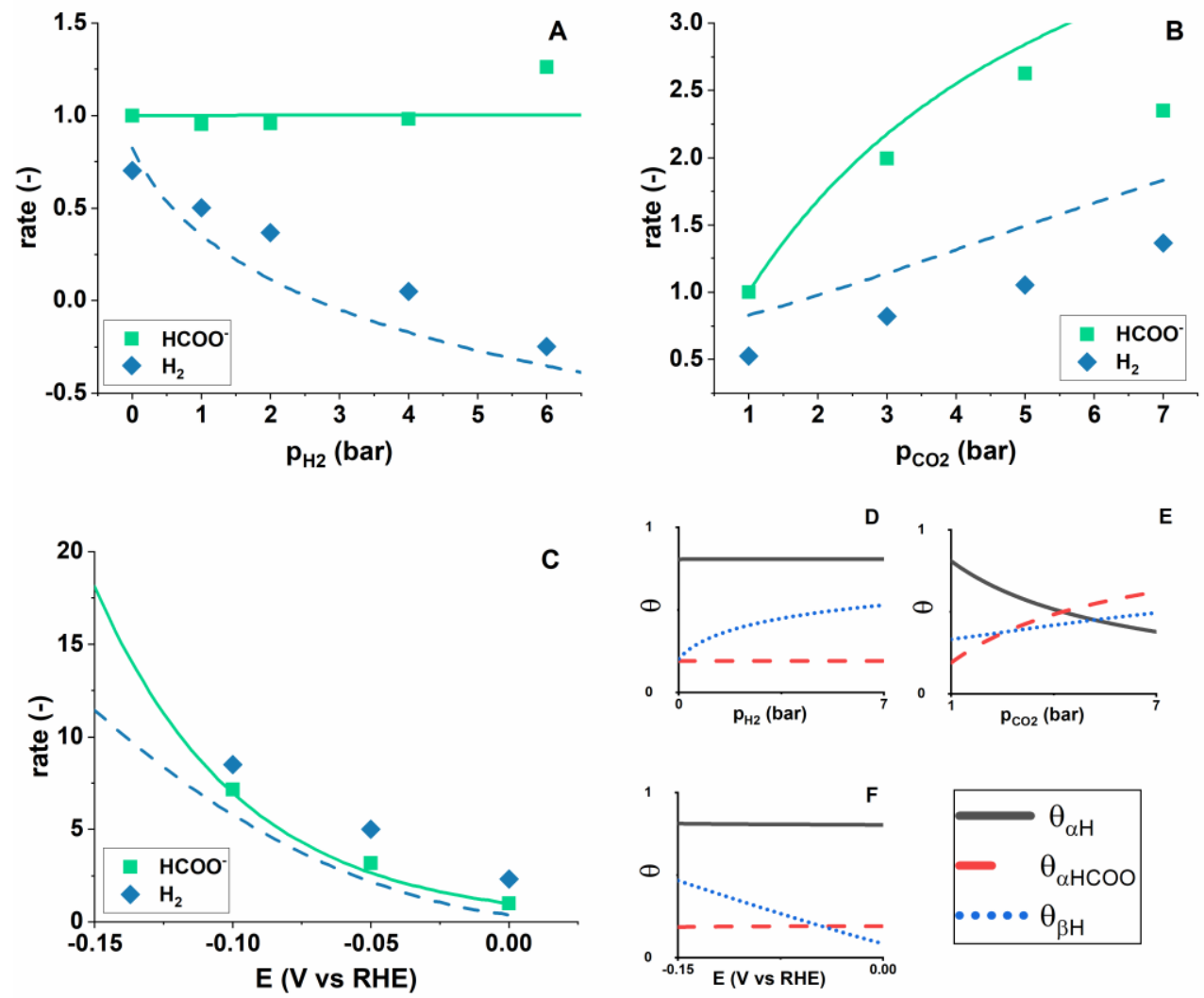

Figure 5.2: (A-C) Formate and hydrogen production during electrochemical $\mathrm{CO}_{2}$ reduction in $\mathrm{1M} \mathrm{KHCO}_{3}$. Lines indicate model result. Solid line indicates $\mathrm{HCOO}^{-}$ and dashed $\mathrm{H}_{2}$. (A) $\mathrm{p}=7 \mathrm{bar}$, pco2 $=1$ bar, $\mathrm{E}=\mathbf{- 0 . 0 5 V}$ vs RHE. Normalised versus

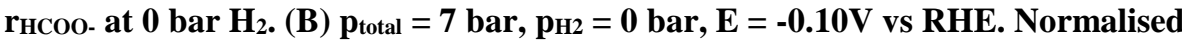

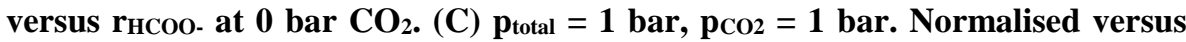
rHCoo- at $0.0 \mathrm{~V}$ vs RHE. (D-F) values of $\theta_{\mathrm{i}}$ corresponding to (A-C).

Figure 5. 2C shows an increase in $\mathrm{r}_{\mathrm{HCOO}}$ and $\mathrm{r}_{\mathrm{H} 2}$ when the potential becomes more cathodic, as expected based on an increased electrochemical driving force. Notably, loading of $\alpha \mathrm{Pd}-\mathrm{H}-$ $\mathrm{COO}$ does not change significantly with potential, rather the increase in $\mathrm{r}_{\mathrm{HCOO}}$ is due to an increase in the electrochemical driving force for $r_{5}$. From Figure 5.2C, the model describes a Tafel slope that increases with more cathodic potential and is between $80-160 \mathrm{mV} / \mathrm{dec}$ for potentials between 0 to $-0.25 \mathrm{~V}$ vs RHE (Figure A5.3), which is consistent with literature. ${ }^{7,8}$ The model correctly describes all trends, and shows a slight offset versus the hydrogen production rate. The latter is due to variations between different electrodes, only normalizing to $\mathrm{r}_{\mathrm{HCOO}}$ and fitting the model to the full data set. Therefore, the best fit over-estimates some values and under-estimates others, but is good on average. If electrode preparation can be 
controlled better and therefore data is less electrode specific, those deviations should decrease. Most importantly, the trends are described correctly, hence experimental observations are conform scheme 5.3.

\section{Predictions with the $\alpha / \beta$-model}

The true value of a model does not lie in an ability to fit, but rather in an ability to explain and predict. Therefore, with the kinetic parameter values fitted in the previous section, the forward reaction for hydrogen evolution $\left(\mathrm{r}_{3}\right)$ is predicted using the $\alpha / \beta$-hydride model. The model predicts an increase in $r_{3}$ as a consequence of the $\beta$-hydride loading $\left(\theta_{\beta_{H}}\right)$ increasing with $p_{\mathrm{H} 2}$. (overall the increase in $r_{3}$ is lower than the increase in $r_{-3}$, thus decreasing net hydrogen evolution). This effect, key to explaining the observed behaviour, was verified experimentally through isotopic labelling of the gas phase.
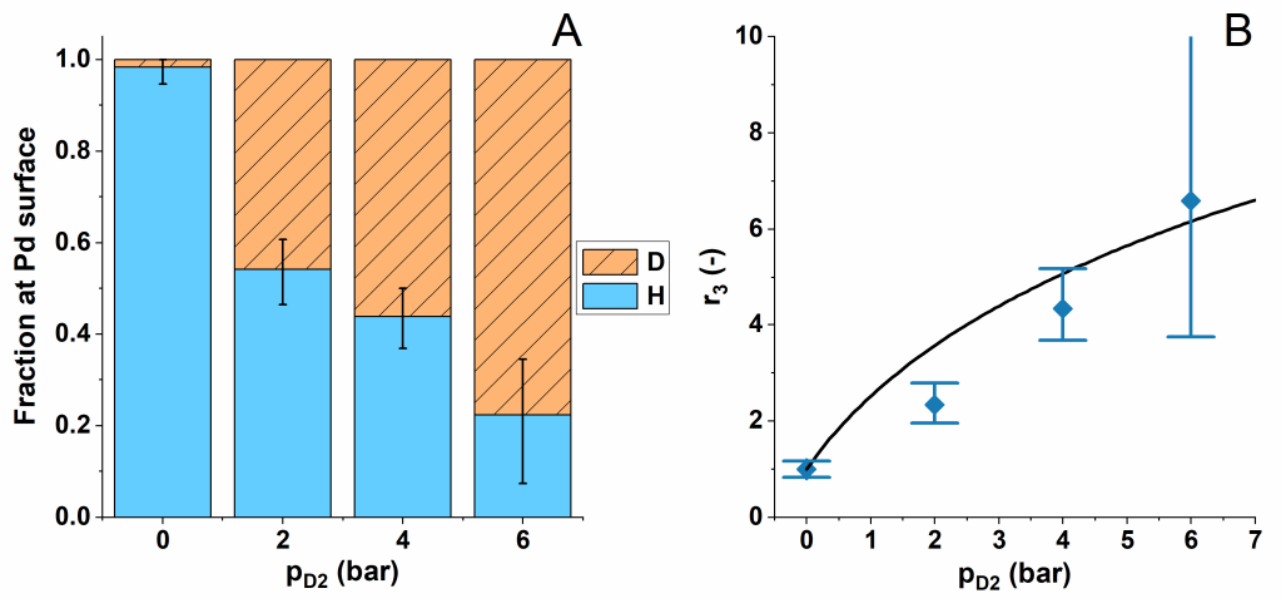

Figure 5.3: Results of $\mathrm{D}_{2}$ labelled experiments in $1 \mathrm{M} \mathrm{KHCO}_{3}$ at $-0.05 \mathrm{~V}$ vs RHE. (A) D and $\mathrm{H}$ fractions at active Pd surface. (B) $r_{3}$ normalised versus $r_{3}$ at 0 bar D2. Line denotes model result.

Deuterium labelling of hydrogen in the gas phase yields three important insights. First, it yields an estimate of the H/D fractions of the palladium hydride sites that are active for hydrogen evolution, which describes the origin of those atoms (H electrochemically from the electrolyte and $\mathrm{D}$ chemically from gas phase $\mathrm{D}_{2}$ ). As expected, Figure 5.3A shows that the $\mathrm{D}$-fraction in the hydride increases as a function of increasing $\mathrm{p}_{\mathrm{D} 2}$. Second, with increased $\mathrm{p}_{\mathrm{D} 2}$, an increased quantity of observed HD under cathodic potential proves combination of electrochemically formed hydride with chemically formed hydride (Figure A5.6), showing that Pd particles are simultaneously active in catalysis and electrocatalysis. Third, $r_{3}$ is estimated from experimental results and shown in Figure 5.3B, together with the model prediction. The $\alpha / \beta$-hydride model correctly predicts the trend in $r_{3}$, without being 
specifically fitted to that data set, which is a strong argument in favour of scheme 5.2 and its simplified from, scheme 5.3.

So far, this chapter explained the data measured in our own laboratory, but will now also consider data provided in the literature. At $-0.10 \mathrm{~V}$ vs RHE, Cai et al. observed a twofold increase in $\mathrm{r}_{\mathrm{HCOO}}$ - without significant effect on current upon addition of 0.2 bar $\mathrm{p}_{\mathrm{H} 2}$ on a $\mathrm{Pd} / \mathrm{C}$ based electrocatalysts. ${ }^{12}$ At $-0.20 \mathrm{~V}$ vs RHE they observe a fourfold increase in $\mathrm{r}_{\mathrm{HCOO}}$ and a twofold increase in current. Ryu and Surendranath report a similar trends at similar conditions, but with only $50 \mathrm{mM} \mathrm{HCO}_{3}{ }^{-}$in solution. ${ }^{13}$ Both publications attribute this to an electrochemical promotion of catalysis (EPOC) effect (an increase of reaction 5.3). However, chemical reactions alone do not contribute to current, hence cannot explain these experimental results fully.

By changing one parameter at a time, two conditions were identified under which the $\alpha / \beta$ hydride model can describe an increase in both $\mathrm{r}_{\mathrm{HCOO}}$ - and current with $\mathrm{p}_{\mathrm{H} 2}$, as observed by Cai et al. and Ryu and Surendranath. ${ }^{12,13}$ First, when the $\alpha / \beta$-hydride equilibrium favours $\beta$ hydride a mild increase is observed as then the $\alpha$-hydride loading increases with $\mathrm{p}_{\mathrm{H} 2}$, thus increasing $\mathrm{r}_{\mathrm{HCOO}}$ (Figure A5.4). Moreover, the $\alpha / \beta$-hydride ratio was found to be a key influence on overall selectivity, as $\beta$-hydride favours hydrogen evolution. We observed a decrease in current and $\mathrm{r}_{\mathrm{H} 2}$, but no effect on $\mathrm{r}_{\mathrm{HCOO}}$ over a much broader $\mathrm{p}_{\mathrm{H} 2}$ range of 0-7 bar. Yet, reaction mechanisms are likely the same in the works of Cai et al., Ryu and Surendranath, and our work, as all consider $\mathrm{Pd} / \mathrm{C}$ catalyst. Kinetic constants, including the ones setting the $\alpha / \beta$-hydride ratio, may however vary due to differences in catalysts and ink properties. Therefore, Pd particle size, morphology and support, which influence the ratio, are highly relevant for catalyst optimization. ${ }^{37}$

Second, when hydride generation is limiting $\mathrm{r}_{5}$, addition of hydrogen results in increased hydride production via $\mathrm{r}_{-3}$, thus increasing $\mathrm{r}_{\mathrm{HCOO}}$ (Figure A5.5). The latter corresponds best to the results by Ryu and Surendranath and Cai et al., meaning that in their cases, $\mathrm{HA}^{+}$ reduction could have been rate limiting when no exogenous hydrogen was present. This should be verified under known mass transfer conditions, for example using Pd deposited on a rotating disk electrode. The $\mathrm{HA}^{+}$reduction rate is strongly influenced by structure and composition of the catalyst ink, which therefore could be a dominant factor in catalyst performance. ${ }^{38}$ The better fit of our model to the data of Cai et al. and Ryu and Surendranath, at $-0.20 \mathrm{~V}$ compared to $-0.10 \mathrm{~V}$ vs RHE, stems from the assumption that $\mathrm{r}_{5}$ occurs fully electrochemical, which gains validity at higher electrochemical driving force. Moreover, the $\alpha / \beta$-hydride model may also explain the effect of $\mathrm{CO}$ poisoning, which leads to decreased formate production and current, thereby increasing selectivity to hydrogen. This could be a result of $\mathrm{CO}$ blocking the $\alpha \mathrm{Pd}$ sites, leaving the $\beta \mathrm{Pd}$ sites mostly unaffected.

This chapter demonstrates that a renounced chemical engineering method to assess plausible reaction mechanisms, namely modelling and verification of trends based on those mechanisms, yields valuable insights in an electrochemical setting. The methodology can be applied with limited experimental and computational resources and allows inclusion of 
various (literature) data sources. The method obviously does not definitively prove the correctness of a mechanism, but is limited to evaluating whether a mathematical description based on a mechanism is consistent with experimental observations. Therefore, it should be evaluated in conjunction with DFT simulations and spectroscopic studies to definitively establish a mechanism.

\subsection{Conclusion}

This work assesses the reaction mechanism of simultaneous electrochemical reduction and hydrogenation of $\mathrm{CO}_{2}$ in $1 \mathrm{M} \mathrm{KHCO}_{3}$ on a $\mathrm{Pd} / \mathrm{C}$ catalyst. Three reactions occur simultaneously on $\mathrm{Pd} / \mathrm{C}$ : Electrochemical formate production, electrochemical hydrogen evolution and chemical hydrogenation of $\mathrm{CO}_{2}$ to formate. By focussing only on trends, plausible literature inspired mechanisms were modelled and evaluated for their ability to describe experimental data. The $\alpha / \beta$-hydride model, with an $\alpha \mathrm{Pd}-\mathrm{H}$ phase that is active for $\mathrm{CO}_{2}$ reduction and a $\beta \mathrm{Pd}-\mathrm{H}$ phase that is active for (reversible) hydrogen evolution, can describe all experimental trends and is consistent with spectroscopic observations in literature. ${ }^{8}$ The mechanism could also correctly describe data by others ${ }^{12,13}$ and was able to predict the outcome of isotopically labelled experiments. Based on the mechanism and model, the $\alpha / \beta \mathrm{Pd}-\mathrm{H}$ ratio and hydride formation rate were identified as key parameters in catalyst performance and behaviour. Control and understanding of both factors should advance catalyst performance and increase inter-laboratory reproducibility. 


\section{References}

(1) Nikolau, B. J.; Perera, M. A. D. N.; Brachova, L.; Shanks, B. Platform Biochemicals for a Biorenewable Chemical Industry. Plant J. 2008, 54 (4), 536-545.

(2) Olah, G. A.; Prakash, G. K. S.; Goeppert, A. Anthropogenic Chemical Carbon Cycle for a Sustainable Future. J. Am. Chem. Soc. 2011, 133 (33), 12881-12898.

(3) Titirici, M. M.; White, R. J.; Brun, N.; Budarin, V. L.; Su, D. S.; Del Monte, F.; Clark, J. H.; MacLachlan, M. J. Sustainable Carbon Materials. Chem. Soc. Rev. 2015, 44 (1), 250-290.

(4) Artz, J.; Müller, T. E.; Thenert, K.; Kleinekorte, J.; Meys, R.; Sternberg, A.; Bardow, A.; Leitner, W. Sustainable Conversion of Carbon Dioxide: An Integrated Review of Catalysis and Life Cycle Assessment. Chem. Rev. 2018, 118 (2), 434-504.

(5) Sakakura, T.; Choi, J. C.; Yasuda, H. Transformation of Carbon Dioxide. Chem. Rev. 2007, 107 (6), 2365-2387.

(6) Aresta, M.; Dibenedetto, A.; Angelini, A. Catalysis for the Valorization of Exhaust Carbon: From CO2 to Chemicals, Materials, and Fuels. Technological Use of CO2. Chem. Rev. 2014, 114 (3), 1709-1742.

(7) Peters, M.; Köhler, B.; Kuckshinrichs, W.; Leitner, W.; Markewitz, P.; Müller, T. E. Chemical Technologies for Exploiting and Recycling Carbon Dioxide into the Value Chain. ChemSusChem 2011, 4 (9), 1216-1240.

(8) Bevilacqua, M.; Filippi, J.; Miller, H. A.; Vizza, F. Recent Technological Progress in CO2 Electroreduction to Fuels and Energy Carriers in Aqueous Environments. Energy Technol. 2015, 3 (3), 197-210.

(9) Larrazábal, G. O.; Martín, A. J.; Pérez-Ramírez, J. Building Blocks for High Performance in Electrocatalytic CO2 Reduction: Materials, Optimization Strategies, and Device Engineering. J. Phys. Chem. Lett. 2017, 8 (16), 3933-3944.

(10) Qiao, J.; Liu, Y.; Hong, F.; Zhang, J. A Review of Catalysts for the Electroreduction of Carbon Dioxide to Produce Low-Carbon Fuels Chem.Soc.Rev. 2014, 43 (2), 631-675

(11) Sun, Z.; Ma, T.; Tao, H.; Fan, Q.; Han, B. Fundamentals and Challenges of Electrochemical CO2 Reduction Using Two-Dimensional Materials. Chem 2017, 3 (4), 560-587.

(12) Lee, C. W.; Cho, N. H.; Im, S. W.; Jee, M. S.; Hwang, Y. J.; Min, B. K.; Nam, K. T. New Challenges of Electrokinetic Studies in Investigating the Reaction Mechanism of Electrochemical CO2 Reduction. J. Mater. Chem. A 2018, 6 (29), 14043-14057.

(13) Sánchez, O. G.; Birdja, Y. Y.; Bulut, M.; Vaes, J.; Breugelmans, T.; Pant, D. Recent Advances in Industrial CO2 Electroreduction. Curr. Opin. Green Sustain. Chem. 2019, 16, 47-56.

(14) Min, X.; Kanan, M. W. Pd-Catalyzed Electrohydrogenation of Carbon Dioxide to Formate: High Mass Activity at Low Overpotential and Identification of the Deactivation Pathway. J. Am. Chem. Soc. 2015, 137, 4701-4708.

(15) Gao, D.; Zhou, H.; Cai, F.; Wang, D.; Hu, Y.; Jiang, B.; Cai, W. Bin; Chen, X.; Si, R.; Yang, F.; Miao, S.; Wang, J.; Wang, G.; Bao, X. Switchable CO2 Electroreduction via Engineering Active Phases of Pd Nanoparticles. Nano Res. 2017, 10 (6), 2181-2191.

(16) Wu, S. Y.; Chen, H. T. CO2 Electrochemical Reduction Catalyzed by Graphene Supported Palladium Cluster: A Computational Guideline. ACS Appl. Energy Mater. 2019, 2 (2), 1544 1552.

(17) Engel, D. C.; Versteeg, G. F.; van Swaaij, W. P. M. Chemical Equilibrium of Hydrogen and Aqueous Solutions of 1:1 Bicarbonate and Formate Salts with a Common Cation. Fluid Phase Equilib. 1997, 135, 109-136.

(18) Blom, M. J. W.; Van Swaaij, W. P. M.; Mul, G.; Kersten, S. R. A. Increased Hydrogen Partial Pressure Suppresses and Reverses Hydrogen Evolution during Pd Catalysed Electrolysis of CO2. Sustain. Energy Fuels 2020, 4 (9), 4459-4463.

(19) Cai, F.; Gao, D.; Zhou, H.; Wang, G.; He, T.; Gong, H.; Miao, S.; Yang, F.; Wang, J.; Bao, X. Electrochemical Promotion of Catalysis over Pd Nanoparticles for CO 2 Reduction. Chem. Sci. 2017, 2569-2573. 
(20) Ryu, J.; Surendranath, Y. Polarization-Induced Local PH Swing Promotes Pd-Catalyzed CO2 Hydrogenation. J. Am. Chem. Soc. 2020, 142 (31), 13384-13390.

(21) Jiang, B.; Zhang, X. G.; Jiang, K.; Wu, D. Y.; Cai, W. Bin. Boosting Formate Production in Electrocatalytic CO2 Reduction over Wide Potential Window on Pd Surfaces. J. Am. Chem. Soc. 2018, 140 (8), 2880-2889.

(22) Klinkova, A.; De Luna, P.; Dinh, C. T.; Voznyy, O.; Larin, E. M.; Kumacheva, E.; Sargent, E. H. Rational Design of Efficient Palladium Catalysts for Electroreduction of Carbon Dioxide to Formate. ACS Catal. 2016, 6 (12), 8115-8120.

(23) Clark, E. L.; Resasco, J.; Landers, A.; Lin, J.; Chung, L. T.; Walton, A.; Hahn, C.; Jaramillo, T. F.; Bell, A. T. Standards and Protocols for Data Acquisition and Reporting for Studies of the Electrochemical Reduction of Carbon Dioxide. ACS Catal. 2018, 8 (7), 6560-6570.

(24) Garg, S.; Li, M.; Weber, A. Z.; Ge, L.; Li, L.; Rudolph, V.; Wang, G.; Rufford, T. E. Advances and Challenges in Electrochemical CO2 Reduction Processes: An Engineering and Design Perspective Looking beyond New Catalyst Materials. J. Mater. Chem. A 2020, 8 (4), 15111544.

(25) Kim, B.; Hillman, F.; Ariyoshi, M.; Fujikawa, S.; Kenis, P. J. A. Effects of Composition of the Micro Porous Layer and the Substrate on Performance in the Electrochemical Reduction of CO2 to CO. J. Power Sources 2016, 312, 192-198.

(26) Wu, J.; Sharma, P. P.; Harris, B. H.; Zhou, X. D. Electrochemical Reduction of Carbon Dioxide: IV Dependence of the Faradaic Efficiency and Current Density on the Microstructure and Thickness of Tin Electrode. J. Power Sources 2014, 258, 189-194.

(27) Shen, H.; Gu, Z.; Zheng, G. Pushing the Activity of CO2 Electroreduction by System Engineering. Sci. Bull. 2019, 64 (24), 1805-1816.

(28) Jhong, H. R. Q.; Brushett, F. R.; Kenis, P. J. A. The Effects of Catalyst Layer Deposition Methodology on Electrode Performance. Adv. Energy Mater. 2013, 3 (5), 589-599.

(29) Li, X.; Wang, S.; Li, L.; Sun, Y.; Xie, Y. Progress and Perspective for In Situ Studies of CO2 Reduction. J. Am. Chem. Soc. 2020, 9576-9581.

(30) Zhu, S.; Jiang, B.; Cai, W. Bin; Shao, M. Direct Observation on Reaction Intermediates and the Role of Bicarbonate Anions in CO2 Electrochemical Reduction Reaction on Cu Surfaces. J. Am. Chem. Soc. 2017, 139 (44), 15664-15667.

(31) Yang, K.; Kas, R.; Smith, W. A. In Situ Infrared Spectroscopy Reveals Persistent Alkalinity near Electrode Surfaces during CO2 Electroreduction. J. Am. Chem. Soc. 2019, 141, 1589115900

(32) Dutta, A.; Kuzume, A.; Rahaman, M.; Vesztergom, S.; Broekmann, P. Monitoring the Chemical State of Catalysts for CO2 Electroreduction: An In Operando Study. ACS Catal. 2015, 5 (12), 7498-7502.

(33) Levenspiel, O. Chemical Reaction Engineering (3rd Edition). John Wiley \& Sons.

(34) Benck, J. D.; Jackson, A.; Young, D.; Rettenwander, D.; Chiang, Y. M. Producing High Concentrations of Hydrogen in Palladium via Electrochemical Insertion from Aqueous and Solid Electrolytes. Chem. Mater. 2019, 31 (11), 4234-4245.

(35) Chase, Z. A.; Fulton, J. L.; Camaioni, D. M.; Mei, D.; Balasubramanian, M.; Pham, V. T.; Zhao, C.; Weber, R. S.; Wang, Y.; Lercher, J. A. State of Supported Pd during Catalysis in Water. J. Phys. Chem. C 2013, 117 (34), 17603-17612.

(36) Goods, S. H.; Guthrie, S. E. Mechanical Properties of Palladium and Palladium Hydride. Scr. Metall. Mater. 1992, 26 (4), 561-565.

(37) Al-Mufachi, N. A.; Rees, N. V.; Steinberger-Wilkens, R. Hydrogen Selective Membranes: A Review of Palladium-Based Dense Metal Membranes. Renew. Sustain. Energy Rev. 2015, 47, 540-551.

(38) Jewell, L. L.; Davis, B. H. Review of Absorption and Adsorption in the Hydrogen-Palladium System. Appl. Catal. A Gen. 2006, 310 (1-2), 1-15.

(39) Dekura, S.; Kobayashi, H.; Ikeda, R.; Maesato, M.; Yoshino, H.; Ohba, M.; Ishimoto, T.; Kawaguchi, S.; Kubota, Y.; Yoshioka, S.; Matsumura, S.; Sugiyama, T.; Kitagawa, H. The 
Electronic State of Hydrogen in the $\alpha$ Phase of the Hydrogen-Storage Material PdH(D)x: Does a Chemical Bond Between Palladium and Hydrogen Exist? Angew. Chemie - Int. Ed. 2018, 57 (31), 9823-9827.

(40) Pentland, N.; Bockris, J. O.; Sheldon, E. Hydrogen Evolution Reaction on Copper, Gold, Molybdenum, Palladium, Rhodium, and Iron. J. Electrochem. Soc. 1957, 104 (3), 182.

(41) Green, T.; Britz, D. Kinetics of the Deuterium and Hydrogen Evolution Reactions at Palladium in Alkaline Solution. J. Electroanal. Chem. 1996, 412 (1-2), 59-66.

(42) Jansonius, R. P.; Schauer, P. A.; Dvorak, D. J.; MacLeod, B. P.; Fork, D. K.; Berlinguette, C. P. Strain Influences the Hydrogen Evolution Activity and Absorption Capacity of Palladium. Angew. Chemie - Int. Ed. 2020, 3, 12192-12198.

(43) Dmitriyeva, O.; Hamm, S. C.; Knies, D. L.; Cantwell, R.; McConnell, M. The Impact of Surface Composition on Tafel Kinetics Leading to Enhanced Electrochemical Insertion of Hydrogen in Palladium. Appl. Surf. Sci. 2018, 440, 224-228.

(44) Parker, S. F.; Walker, H. C.; Callear, S. K.; Grünewald, E.; Petzold, T.; Wolf, D.; Möbus, K.; Adam, J.; Wieland, S. D.; Jiménez-Ruiz, M.; Albers, P.W. The Effect of Particle Size, Morphology and Support on the Formation of Palladium Hydride in Commercial Catalysts. Chem. Sci. 2019, 10 (2), 480-489.

(45) Jervis, R.; Mansor, N.; Sobrido, A. J.; Jones, S.; Gibbs, C.; Neville, T. P.; Millichamp, J.; Shearing, P. R.; Brett, D. J. L. The Importance of Using Alkaline Ionomer Binders for Screening Electrocatalysts in Alkaline Electrolyte. J. Electrochem. Soc. 2017, 164 (14), F1551-F1555.

(46) Holleck, G. L.; Flanagan, T. B. The Mechanism for Exchange between Aqueous Solutions and Deuterium Gas on Palladium Surfaces. J. Phys. Chem. 1969, 73 (2), 285-292. 


\section{Appendix}

\section{A5.1 Model equations and assigning parameter values}

The rate equations and reactions that describe scheme 5.3 are presented in Tables A5.1 and A5.2. Equations A5.1-A5.9 describe the reaction rates. Equations A5.10 and A5.11 describe dissolved gas concentrations, A5.12-A5.16 are balances over the sites and intermediates, and equations A5.17-A5.20 describe the equilibrium between carbon dioxide, bicarbonate and carbonate, which is used to calculate the $\mathrm{pH}$ of the solution. Given the number of parameters and the uncertainty in the experimental data, fitting rate constants would not yield sensible results. However, by reasoning from the trends (Table 5.1 and Figure 5.2), literature data, and trial and error, a set of parameters with which the model describes these the trends was found, as detailed below.

The $\alpha$-hydride phase is formed at lower overpotential and/or hydrogen pressure than the $\beta$ hydride phase. Therefore, $\mathrm{k}_{2}$ is set to a higher value then $\mathrm{k}_{-2}$, which forces the hydride equilibrium towards $\alpha$-hydride. Moreover, both constants have a relatively large value, to create equilibrium between $\alpha$ - and $\beta$-hydride. $\mathrm{k}_{4}, \mathrm{k}_{-4}$ and $\mathrm{k}_{5}$ are such that $\mathrm{CO}_{2}$ adsorption and electron transfer to adsorbed $\mathrm{CO}_{2}$ control the formate production rate, thus creating an increase in $\mathrm{r}_{\mathrm{HCOO}}$ as a function of both an increasing $\mathrm{p}_{\mathrm{CO} 2}$ and increasing cathodic potential. Finally, the remaining constants must describe an intermediate loading of the $\beta$-hydride phase, allowing both $r_{1}$ and $r_{-3}$ to influence the hydrogen evolution rate. $k_{5}$ is set to a value of 1, as model results are later normalised. Table A5.3 shows the values of the constants.

Table A5.1: Rate equations and reactions corresponding to scheme 3

\begin{tabular}{ll}
\hline Equation & Description \\
\hline$r_{1}=\left(k_{1, a} c_{H^{+}}+k_{1, b}\right) \exp \left(-\frac{\alpha_{1} F}{R T}(E-\right.$ & $H^{+}+e^{-}+P d \rightarrow \beta P d H$ \\
$\left.\left.E_{1}^{e q}\right)\right) \theta_{\beta 0}$ & $H_{2} O+e^{-}+P d \rightarrow \beta P d H+O H^{-}$ \\
& $($Proton reduction to hydride $)$ \\
$r_{-1}=k_{-1} \exp \left(\frac{\left(1-\alpha_{1}\right) F}{R T}\left(E-E_{1}^{e q}\right)\right) \theta_{\beta H}$ & $\beta P d H \rightarrow H^{+}+e^{-}+P d$ \\
& $($ Hydride oxidation $)$ \\
$r_{2}=k_{2} \theta_{\beta H} \theta_{\alpha 0}$ & $\alpha P d+\beta P d H \rightarrow \alpha P d H+\beta P d$ \\
& $(\beta-\alpha$ hydrogen transfer $)$ \\
$r_{-2}=k_{-2} \theta_{\alpha H} \theta_{\beta 0}$ & $\alpha P d H+\beta P d \rightarrow \alpha P d+\beta P d H$ \\
$r_{3}=k_{3} \theta_{\beta H}^{2}$ & $(\alpha-\beta$ hydrogen transfer) \\
& $2 \beta P d H \rightarrow H_{2}+2 P d$ \\
$r_{-3}=k_{-3} c_{H 2} \theta_{\beta 0}^{2}$ & $($ Tafel step) \\
& $H_{2}+2 P d \rightarrow 2 \beta P d H$ \\
& $($ Reverse Tafel step)
\end{tabular}




$$
\begin{array}{ll}
r_{4}=k_{4} \theta_{\alpha H} c_{C O_{2}} & \alpha P d H+\mathrm{CO}_{2} \rightarrow \alpha P d \mathrm{HCO}_{2} \\
r_{-4}=k_{-4} \theta_{\alpha \mathrm{CO}_{2}} & \left(\text { Reactive } \mathrm{CO}_{2}\right. \text { adsorption) } \\
& \alpha P d \mathrm{HCO}_{2} \rightarrow \alpha P d H+\mathrm{CO}_{2} \\
r_{5}=k_{5} \exp \left(-\frac{\alpha_{5} F}{R T}\left(E-E_{5}^{e q}\right)\right) \theta_{\alpha \mathrm{COO}_{2}} & \left(\text { Reactive } \mathrm{CO}_{2}\right. \text { desorption) } \\
& \alpha P d \mathrm{HCO}_{2}+e^{-} \rightarrow \mathrm{HCOO}^{-} \\
& \text {(Formate formation) }
\end{array}
$$

\begin{tabular}{|c|c|c|}
\hline Equation & Description & \\
\hline$c_{H 2}=H_{H 2} p_{H 2}$ & Hydrogen concentration & $(\mathrm{A} 5.10)$ \\
\hline$c_{\mathrm{CO} 2}=H_{\mathrm{CO} 2} p_{\mathrm{CO} 2}$ & Carbon dioxide concentration & (A5.11) \\
\hline$\theta_{\alpha 0}+\theta_{\alpha H}+\theta_{\alpha H C O_{2}}=1$ & $\alpha$-site balance & $(\mathrm{A} 5.12)$ \\
\hline$\theta_{\beta 0}+\theta_{\beta H}=1$ & $\beta$-site balance & $(\mathrm{A} 5.13)$ \\
\hline$r_{2}+r_{-4}-r_{-2}-r_{4}=0$ & Balance over $\alpha \mathrm{Pd}-\mathrm{H}$ & (A5.14) \\
\hline$r_{1}+r_{-2}+2 r_{-3}-r_{-1}-r_{2}-2 r_{3}=0$ & Balance over $\beta \mathrm{Pd}-\mathrm{H}$ & $(\mathrm{A} 5.15)$ \\
\hline$r_{4}-r_{-4}-r_{5}=0$ & Balance over adsorbed $\mathrm{CO}_{2}$ & (A5.16) \\
\hline$\frac{c_{\mathrm{HCO}_{3}^{-}}}{\mathrm{H}_{\mathrm{CO}_{2} p_{\mathrm{CO}_{2}}{ } \mathrm{OH}^{-}}}=K_{6}$ & $\mathrm{CO}_{2}+\mathrm{OH}^{-} \rightleftarrows \mathrm{HCO}_{3}^{-}$ & $(\mathrm{A} 5.17)$ \\
\hline$\frac{{ }^{c} \mathrm{CO}_{3}^{2-}}{c_{\mathrm{HCO}_{3}^{-}} \mathrm{COH}^{-}}=K_{7}$ & $\mathrm{HCO}_{3}^{-}+\mathrm{OH}^{-} \rightleftarrows \mathrm{CO}_{3}^{2-}+\mathrm{H}_{2} \mathrm{O}$ & (A5.18) \\
\hline$c_{O H^{-}} c_{H^{+}}=K_{W}$ & $\mathrm{OH}^{-}+\mathrm{H}^{+} \rightleftarrows \mathrm{H}_{2} \mathrm{O}$ & $(\mathrm{A} 5.19)$ \\
\hline$c_{K^{+}}+c_{H^{+}}-2 c_{C_{3}^{2-}}-c_{H_{C O}^{-}}-c_{O_{H}^{-}}=0$ & Ionic charge balance & $(\mathrm{A} 5.20)$ \\
\hline
\end{tabular}

Table A5.2: Equations and reactions corresponding to scheme 3 . $\mathrm{H}_{\mathrm{i}}$ denotes Henry constant and $K_{n}$ denotes equilibrium constant.

\section{Equations D2 labelled experiments}

$$
\begin{aligned}
& r_{H 2}=\mathrm{k}_{\mathrm{HER}}\left(C_{H}^{S}\right)^{2} \\
& r_{H D}=2 \mathrm{k}_{\mathrm{HER}} \frac{1}{K I E} C_{H}^{S} C_{D}^{S} \\
& r_{D 2}=\mathrm{k}_{\mathrm{HER}} \frac{1}{K I E^{2}}\left(C_{D}^{S}\right)^{2} \\
& \frac{2 r_{H 2}}{r_{H D}} \frac{1}{K I E}=\frac{2 \mathrm{k}_{\mathrm{HER}}\left(C_{H}^{S}\right)^{2}}{2 \mathrm{k}_{\mathrm{HER}} \frac{1}{K I E} C_{H}^{S} C_{D}^{S}} \frac{1}{K I E}=\frac{C_{H}^{S}}{C_{D}^{S}} \\
& \frac{C_{H}^{S}}{C_{D}^{S}+C_{H}^{S}}=\frac{\frac{2 r_{H 2} 1}{r_{H D} K I E}}{1+\frac{2 r_{H 2} 1}{r_{H D} K I E}}
\end{aligned}
$$




$$
\begin{aligned}
& \frac{\left(r_{H D}\right)^{2}}{4 r_{H 2}}=\frac{4\left(\mathrm{k}_{\mathrm{HER}}\right)^{2} \frac{1}{K I E^{2}}\left(C_{H}^{S}\right)^{2}\left(C_{D}^{S}\right)^{2}}{4 \mathrm{k}_{\mathrm{HER}}\left(C_{H}^{S}\right)^{2}}=\mathrm{k}_{\mathrm{HER}} \frac{1}{K I E^{2}}\left(C_{D}^{S}\right)^{2}=r_{D 2} \\
& r_{3}=r_{H 2}+r_{H D}+\frac{\left(r_{H D}\right)^{2}}{4 r_{H 2}} \\
& \mathrm{KIE} \approx 1.2
\end{aligned}
$$

\begin{tabular}{|c|c|c|}
\hline Constant & Value & Unit \\
\hline$k_{1, a}$ & $2 \cdot 10^{7}$ & $s^{-1}$ \\
\hline$k_{1, b}$ & 0.5 & mole $L^{-1} s^{-1}$ \\
\hline$k_{-1}$ & $7 \cdot 10^{6}$ & mole $L^{-1} s^{-1}$ \\
\hline$k_{2}$ & $2 \cdot 10^{6}$ & mole $L^{-1} s^{-1}$ \\
\hline$k_{-2}$ & $1 \cdot 10^{3}$ & mole $L^{-1} s^{-1}$ \\
\hline$k_{3}$ & 10 & mole $L^{-1} s^{-1}$ \\
\hline$k_{-3}$ & 2500 & $s^{-1}$ \\
\hline$k_{4}$ & 3500 & $s^{-1}$ \\
\hline$k_{-4}$ & 500 & mole $L^{-1} s^{-1}$ \\
\hline$k_{5}$ & 1 & mole $L^{-1} s^{-1}$ \\
\hline$\alpha_{1}$ & 0.5 & - \\
\hline$\alpha_{5}$ & 0.5 & - \\
\hline$E_{1}^{e q}$ & 0 & $V$ vs $R H E$ \\
\hline$E_{5}^{e q}$ & 0 & $V$ vs $R H E$ \\
\hline$K_{6}$ & $4.44 \cdot 10^{7}$ & $L$ mole ${ }^{-1}$ \\
\hline$K_{7}$ & $4.66 \cdot 10^{3}$ & L mole $^{-1}$ \\
\hline$K_{W}$ & $1 \cdot 10^{-14}$ & mole ${ }^{2} L^{-2}$ \\
\hline $\mathrm{H}_{\mathrm{CO} 2}$ & 0.034 & mole $L^{-1} b a r^{-1}$ \\
\hline$H_{H 2}$ & $7.8 \cdot 10^{-4}$ & mole $L^{-1} b_{a r}^{-1}$ \\
\hline$R$ & 8.31 & $J K^{-1}$ mole $^{-1}$ \\
\hline$T$ & 298 & $K$ \\
\hline$F$ & 96485 & $s$ A mole ${ }^{-1}$ \\
\hline
\end{tabular}

Table A5.3: Constants and their values. Not scaled to experimental values, therefore $k_{5}$ has value of 1 . 


\section{A5.2 Additional results}

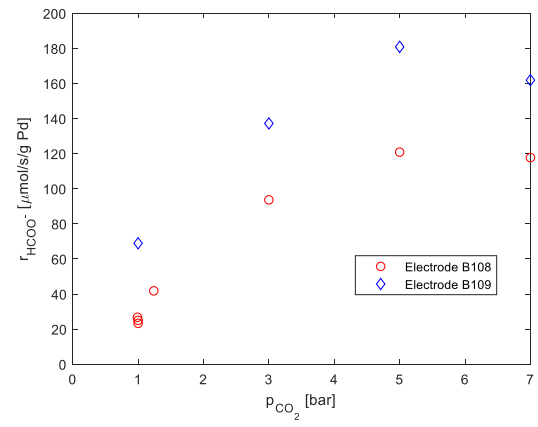

Figure A5.1: Difference between two electrodes for formate production rate at $0.10 \mathrm{~V}$ vs $\mathrm{RHE}$ in $\mathrm{IM} \mathrm{KHCO}_{3}$ and 7 bar total pressure with various $\mathrm{CO}_{2}$ and $\mathrm{Ar}$ partial pressures.

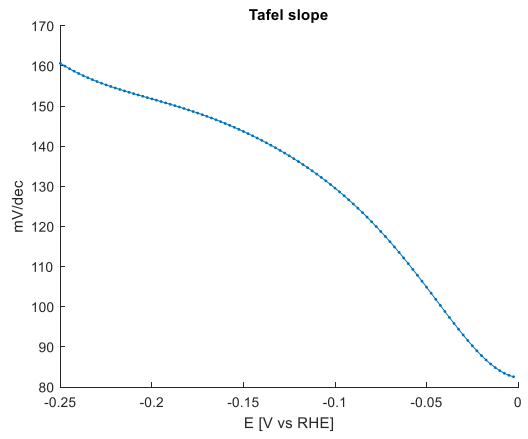

FigureA5.3: Modelled Tafel slope at various potentials in $1 \mathrm{M} \mathrm{KHCO}_{3}$ at 1 bar $\mathrm{CO}_{2}$ pressure.

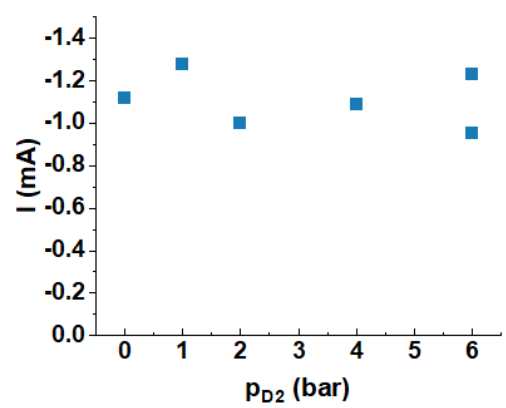

Figure A5.2: Current versus $\mathrm{p}_{\mathrm{D} 2}$ for $\mathrm{Pd} / \mathrm{C}$ electrode in $1 \mathrm{M} \mathrm{KOH}$ at $\mathbf{- 0 . 0 5} \mathrm{V}$ vs RHE in the absence of $\mathrm{CO}_{2}$.

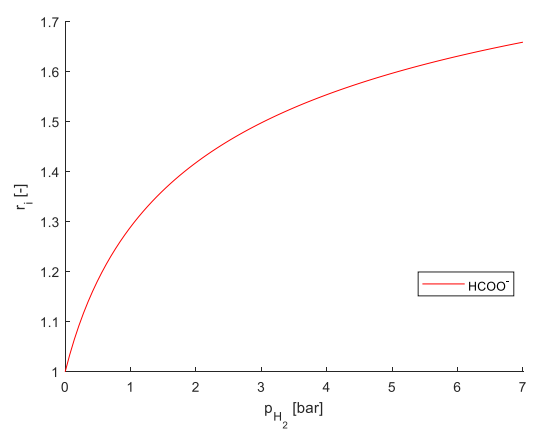

Figure A5.4: Model result for $\mathrm{HCOO}^{-}$at 1 bar $\mathrm{CO}_{2}$ and $-0.05 \mathrm{~V}$ vs RHE in $1 \mathrm{M} \mathrm{KHCO}_{3}$, when the value of $k_{2}$ is changed to 2000 


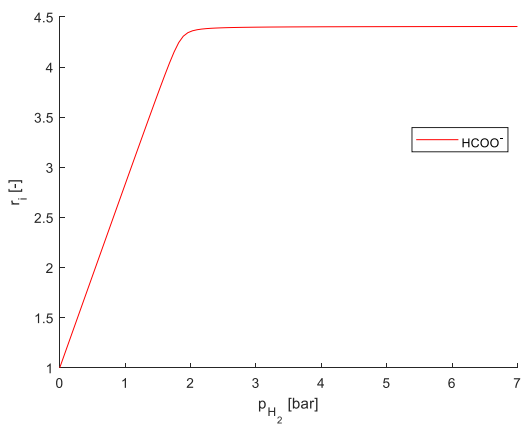

Figure A5.5: Model result for $\mathrm{HCOO}^{-}$ at 1 bar $\mathrm{CO}_{2}$ and $-\mathbf{0 . 0 5} \mathrm{V}$ vs RHE in 1 $\mathrm{M} \mathrm{KHCO}_{3}$, when the value of $\mathrm{k}_{5}$ is changed to 20 , thus creating rate determining proton reduction rate.

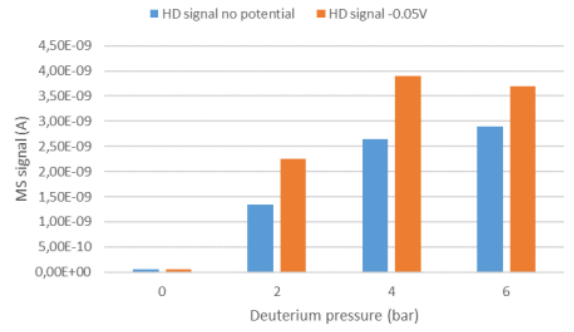

Figure A5.6: HD signal from $\mathrm{Pd} / \mathrm{C}$ electrode in $1 \mathrm{M} \mathrm{KHCO}_{3}$, with and without applied potential 




\section{Chapter 6}

\section{Conclusion, Outlook and Perspective}

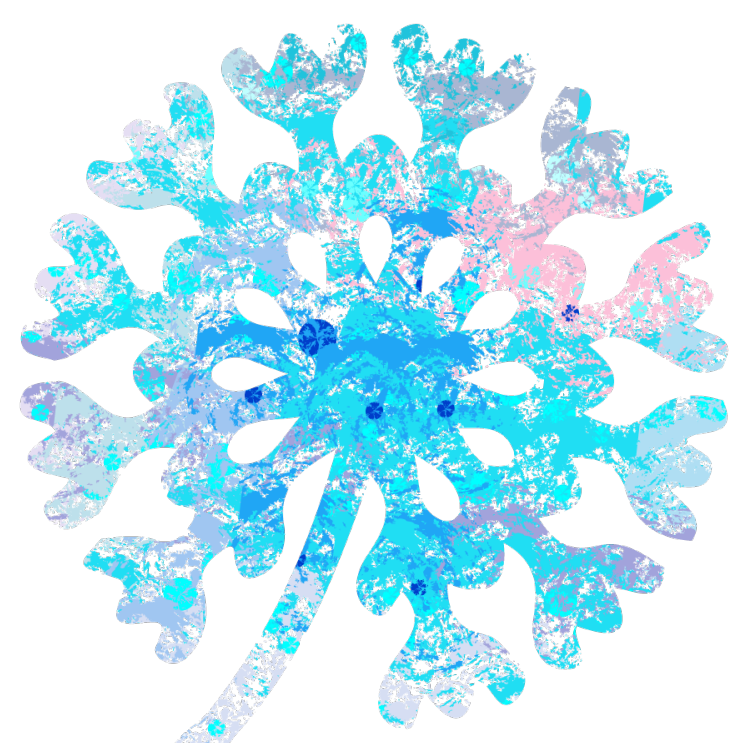

'Het leven van een kind moet zo onbezorgd zijn als een helderblauwe hemel'

- Johanna Leusink-Roos - 


\subsection{Conclusions}

In this thesis, the electrochemical conversion of bicarbonate to formate for the purpose of energy storage was studied. Driven by electric energy, bicarbonate ions are converted to stable, energy-rich formate ions, which can be stored. Later, formate can be electrochemically reconverted to bicarbonate, releasing the stored energy as electricity and heat. Alternatively, formate can be dehydrogenated, to bicarbonate and releasing hydrogen gas on-demand. Thereby creating a safe energy storage system with the potential flexibility of releasing stored energy in the form of power or hydrogen.

Production of formate is oftentimes researched in the presence of both bicarbonate $\left(\mathrm{HCO}_{3}^{-}\right)$ and $\mathrm{CO}_{2}$. Therefore, it is debatable whether $\mathrm{CO}_{2}$ or bicarbonate is the electrochemically active species. In chapter 2, mass balance analyses showed that when both species are present, the overall conversion of a $\mathrm{CO}_{2} / \mathrm{HCO}_{3}{ }^{-}$reactor is unaffected by which is the actual active species, due to the carbonaceous equilibrium between $\mathrm{CO}_{2}$ and $\mathrm{HCO}_{3}{ }^{-}$. Consequently, $\mathrm{CO}_{2}$ reduction electrodes can be used for the conversion of bicarbonate to formate and vice versa. Moreover, the mass balance analysis showed that net overall conversion of bicarbonate to exclusively formate and oxygen occurs when only protons are transported through the membrane to the catholyte. Therefore, bipolar membranes with alkaline anolyte or cation exchange membranes with acidic anolyte are recommended for further studies.

$\mathrm{Pb}$ electrodes, which were studied in chapter 3, show high initial selectivity to formate. The electrodes were found to deactivate quickly under cathodic polarization. By short anodic polarization, activity could be restored, increasing the average rate and selectivity towards formate. With in-situ Raman spectroscopy and thermodynamic analysis, this effect was attributed to a meta-stable $\mathrm{PbCO}_{3}$ layer, active for $\mathrm{CO}_{2}$ reduction, which is (re)generated during anodic polarization. Therefore, pulsed operation can improve the average activity of $\mathrm{Pb}$ electrodes compared to continuous cathodic polarization. However, despite enhancements by pulsed operation, the high overpotential on $\mathrm{Pb}$ electrodes required for formate production $(\sim 1 \mathrm{~V})$ resulted in too much energy loss $(\sim 200 \mathrm{KJ} / \mathrm{mole}$ formate $)$ for application of $\mathrm{Pb}$ electrodes in the bicarbonate-formate system.

Palladium was identified, in chapter 4, as an electrocatalysts with low overpotential, but also low intrinsic selectivity to formate. Up to $50 \%$ of electrons were consumed in undesired hydrogen production. However, $\mathrm{Pd}$ catalysts are known to hydrogenate bicarbonate chemically to formate at elevated hydrogen pressures. It was hypothesized that increasing the hydrogen pressure in the electrochemical cell could reduce further hydrogen formation. To that end a novel electrochemical cell was designed and characterized, which can operate at elevated pressure whilst still incorporation a stable reference electrode and membrane. With this cell, the selectivity could be steered towards formate, by increasing the hydrogen partial pressure. At mild pressure, as low as 4 bar partial pressure of hydrogen, net $\mathrm{H}_{2}$ production could be avoided without any effect on the formate production rate.

The applied hydrogen pressure was not high enough to prevent hydrogen evolution by a simple increase in the equilibrium potential as calculated via Nernst's law and shown 
experimentally at identical partial pressure of hydrogen and overpotential, in the absence of $\mathrm{CO}_{2}$, bicarbonate and formate. Therefore, the origin of this effect was studied based on potential reaction mechanisms, including $\mathrm{CO}_{2}$, hydrogen and formate, in chapter 5 . Modelling of those mechanisms and comparison of modelled trends to experimentally observed trends, pointed to a mechanism based on two hydride phases. In that mechanism, an $\alpha$-hydride phase is active for $\mathrm{CO}_{2}$ reduction and a $\beta$-hydride phase for hydrogen evolution. Based on the mechanism and model, the outcome of isotopically labelled experiments was predicted correctly.

Regarding the development of the bicarbonate-formate storage system, the findings in this thesis lead to three main insights. First, the system development should not be troubled by uncertainty in the reactive species being $\mathrm{CO}_{2}$ or bicarbonate, as both will yield equal overall balances. Second, development should not only focus on high specific current densities, but also on lowering overpotential to limit energy losses, which are for many $\mathrm{CO}_{2}$ reduction catalysts much higher than $\mathrm{H}_{2}$ evolution catalysts. Lastly, as increased partial pressure of hydrogen can prevent hydrogen evolution, an electrocatalysts exhibiting significant intrinsic side production of hydrogen should not necessarily impede selective formate production. When formate is the sole $\mathrm{CO}_{2}$ reduction product, after an initial accumulation of $\mathrm{H}_{2}$ in the cell, the steady state conversion can be selective conversion of bicarbonate to formate.

\subsection{Outlook}

The major advantage of the bicarbonate-formate storage system, as identified in the introduction, is its safety. Bicarbonate and formate are both non-flammable, non-toxic chemicals, thereby rendering the system suitable for energy storage in and near urban areas. However, in chapters 4 and 5 it was found that pressurized hydrogen, a flammable gas with wide explosion limits in air, must be present in the reactor. This does however not devalue the safety advantages of the bicarbonate-formate process. The presence of hydrogen is only required in the reactor (where the catalyst is). Outside the reaction environment, formate is stable. Therefore, the materials that are stored, which constitute to a much larger amount than the reactor inventory, do not need to contain hydrogen gas and still have a large safety advantage.

Throughout this theses, various challenges for further development of the system were identified. The $\mathrm{Pd} / \mathrm{C}$ catalyst used in chapters 4 and 5 has the obvious disadvantage of palladium being expensive and scarce. The highest observed rate to formate (in chapter 4) was $120 \mu \mathrm{mol} / \mathrm{s} / \mathrm{g} \mathrm{Pd}$. Consequently, to reach a typical productivity of $1 \mathrm{~mol} / \mathrm{m}_{\mathrm{r}}{ }^{3} / \mathrm{s}$, the palladium loading of a reactor should be $8 \mathrm{~kg}_{\mathrm{Pd}} / \mathrm{m}_{\mathrm{r}}{ }^{3}$. At $€ 60000$ per $\mathrm{kg} \mathrm{Pd}$, such amounts are too expensive. However, the catalyst utilization has not been studied in this thesis. Electrodes were constructed by impregnating a catalyst ink into a porous carbon paper, resulting in a mixture of $\mathrm{Pd} / \mathrm{C}$ and ionomer (ion conductive polymer) inside a porous carbon matrix of 210 $\mu \mathrm{m}$ thick. Ionomer could have blocked the pores of the activated carbon, reducing the available catalyst area. Moreover, the dense ionomer layer might hinder mass transport into the electrode, resulting in a low effectiveness factor. The highest observed rate in this work is an order of magnitude lower than the rates observed by Engel in purely catalytic 
hydrogenation of $\mathrm{CO}_{2}$ in well-dispersed $\mathrm{Pd} / \mathrm{C}$ slurry ${ }^{1}$, whereas it is similar to the electrochemical rates observed by others ${ }^{2}$. An indication that the catalyst ink negatively influences the availability of the catalytic sites or mass transfer into the electrode. Therefore, studies should be conducted on the catalyst utilization of these electrodes and the necessity and benefits of the presence of ionomer in electrodes designed for liquid phase electrolysis. Based on the results, decisions can be made whether a less expensive catalyst is needed and/or the catalyst utilization must be improved.

Another challenge, already identified by studies on chemical conversion of bicarbonate to formate, is deactivation of the $\mathrm{Pd} / \mathrm{C}$ catalyst. ${ }^{3}$ Poisoning of the catalyst by small amounts of $\mathrm{CO}$ produced in a side reaction is well accepted as the origin of this deactivation in both the chemical as in the electrochemical process. ${ }^{2,4,5}$ In chapter 4 , is was shown that brief anodic polarization could restore catalyst activity (Figure A4.3), which others also found. ${ }^{6}$ Alternatively, exposure to oxygen can restore catalyst activity. ${ }^{2}$ Therefore, catalyst deactivation should not be a showstopper for implementation of $\mathrm{Pd} / \mathrm{C}$ in electrochemical reactors. Moreover, anodic regeneration may prove advantageous to chemical processes as well, if current can be introduced effectively into the catalyst bed.

Crossover of formate to the anolyte results in destruction of formate at the anode, therefore an ion selective membrane must be present in the electrochemical reactor. This is a disadvantage of formate compared to gaseous $\mathrm{CO}_{2}$ reduction products (e.g. $\mathrm{CO}$, ethylene, etc.), whose concentration is limited to their gas solubility, whereas formate accumulates in the electrolyte. Chapter 2 identified bipolar membranes as potential favourable membranes, compared to cation exchange membranes, as they may offer stable $\mathrm{pH}$ in the reactor and favourable alkaline conditions for the oxygen evolution reaction. Crossover of formate relative to the total ionic flux is especially significant at lower total ion fluxes (at low current density). ${ }^{7}$ Therefore, high ion fluxes through the membrane are required. When 3D cathodes are used, the geometric current density, at constant potential, can be increased by increasing cathode thickness and catalyst loading. Consequently, 3D cathodes combined with improvements in membrane technology could optimise the cell for high productivity and low crossover, without excessive overpotential. Moreover, direct coating of catalyst on the membrane could result in locally elevated $\mathrm{CO}_{2}$ concentrations, hence improved kinetics and mass transfer, due to reaction with protons (transported through the membrane) and $\mathrm{HCO}_{3}$.

The introduction identified significant research effort dedicated to direct formate fuel cells. Between 2018 to 2020, on average 24 articles were published annually on this topic ${ }^{\ddagger}$. Much research was directed towards development of improved formate oxidation catalysts ${ }^{8-10}$, better electrode structures ${ }^{11,12}$ and optimisation of the full cell ${ }^{13-16}$. However, nearly all works consider alkaline formate solutions, containing up to $4 \mathrm{~mole} / \mathrm{L} \mathrm{KOH}{ }^{12}$ Added hydroxide results in carbonate formation (6.1) rather than bicarbonate (6.2). Therefore, as the overall reaction and conditions are changed, addition of $\mathrm{KOH}$ results in higher cell potentials and power density, but consequently also net hydroxide consumption. The latter is

\footnotetext{
‡Web of Science search for: "direct formate fuel cell"
} 
detrimental to the cyclicity of the bicarbonate-formate storage system. Few publications regard direct formate fuel cells without added hydroxide to the system. One publication compares $1 \mathrm{M}$ formate feed with and without a presence of $2 \mathrm{M} \mathrm{KOH}$, peak power densities are 300 and $120 \mathrm{~mW} / \mathrm{cm}^{2}$ respectively. ${ }^{17}$ Concluding, recovery of the electric energy after storage, via either a direct formate fuel cell or chemically releasing $\mathrm{H}_{2}$ from formate followed by utilization in a commercially available hydrogen fuel cell, requires more attention.

$$
\begin{array}{ll}
\mathrm{HCOO}^{-}+\mathrm{OH}^{-}+\frac{1}{2} \mathrm{O}_{2} \rightleftarrows \mathrm{CO}_{3}^{2-}+\mathrm{H}_{2} \mathrm{O} & E^{0}=1.45 \mathrm{~V} \\
\mathrm{HCOO}^{-}+\frac{1}{2} \mathrm{O}_{2} \rightleftarrows \mathrm{HCO}_{3}^{-} & E^{0}=1.22 \mathrm{~V}
\end{array}
$$

In this thesis, several key challenges for development of the bicarbonate-formate system were addressed, related to the reactive species, selectivity and energy efficiency. Other challenges remain, such as achieving significant formate concentrations, analyses of a complete electrolyzer including membrane and anode, and demonstrating system cyclicity. Moreover, new challenges were identified, in particular catalyst costs, product crossover through the membrane and the productivity of low-alkaline direct fuel cells. These challenges are by no means unique to the bicarbonate-formate system, as many electrochemical conversion systems suffer from the same effects. ${ }^{17-21}$ Therefore, potential solutions are relevant to many processes. Given the promise of a safe storage medium, the absence (at present) of fundamental show-stoppers and research and development challenges relevant to many electrochemical conversion technologies, it is advisable to continue research on this system.

\subsection{Perspective}

Historically, electrochemical processes have fulfilled relatively few roles in industrial scale conversions. Some examples of notable industrial applications are the chlor-alkali process, the Hall-Héroult process for aluminium extraction, reductive coupling of acrylonitrile to form adiponitrile (a Nylon 66 precursor) and metal ion removal and recovery. ${ }^{22}$ Therefore, for decades the scientific field of electrochemistry has been largely dominated by more fundamental research. Wind and solar energy generation has become increasingly mainstream and consequently the availability and cost-competitiveness of renewable electricity is increasing, a trend that will almost certainly continue. ${ }^{23}$ Incorporation of this energy source into industrial processes, electrification of the industry, has become a major topic of interest. ${ }^{24,25}$ This is reflected in scientific literature, where industrially relevant performance indicators, such as selectivity (Faraday efficiency), conversion, productivity (current density) and capital expenditures, have become increasingly important. Many research groups with a strong engineering basis, e.g. this group (Enschede), the MECS group (Delft), the Kenis research group (Illinios) and the Alexis Bell research group (Berkeley) are currently active in the field of electrochemistry.

In the view of the author, three main disciplines should contribute to the field of electrochemistry. First, traditional electrochemists who master electrochemical analysis techniques (cyclic voltammetry, impedance spectroscopy, etc.). Second, material scientists, who specialise in electro-catalyst development and spectroscopic analysis thereof. Third, 
process engineers, who focus on scale-up and overall performance by reactor design and analysing operating conditions.

Ideally, all disciples work together extensively and in harmony. Material scientists develop new materials, which are further evaluated by electrochemists. Cooperation between both disciplines yields insights and optimisation of factors affecting catalyst performance and development of electrode materials from electro-catalysts. Similarly, engineers place electrode materials in conversion reactors, optimise operating conditions and identify bottlenecks in the system. Feedback to the other disciplines results in updated optimization goals for material scientists and electrochemists. In this way, the three disciplines apply different selection criteria, even for the same performance indicator. E.g. to assess reaction rate (Figure 6.1): On the electro-catalyst level, the turnover frequency should be used, focussing only on the active sites. On the electrode-material level, the current density per electro-active area should be used, focussing in detail on how many active groups can be attached per unit of actual area. On the electrode or full cell level, current density per geometric area and productivity $\left(\mathrm{mol} / \mathrm{m}^{3}\right.$ electrode $\left./ \mathrm{s}\right)$ are relevant, focussing on the actual rate obtained in the device. With such criteria, assessment is based on the most important aspects in that specific step of technology development.

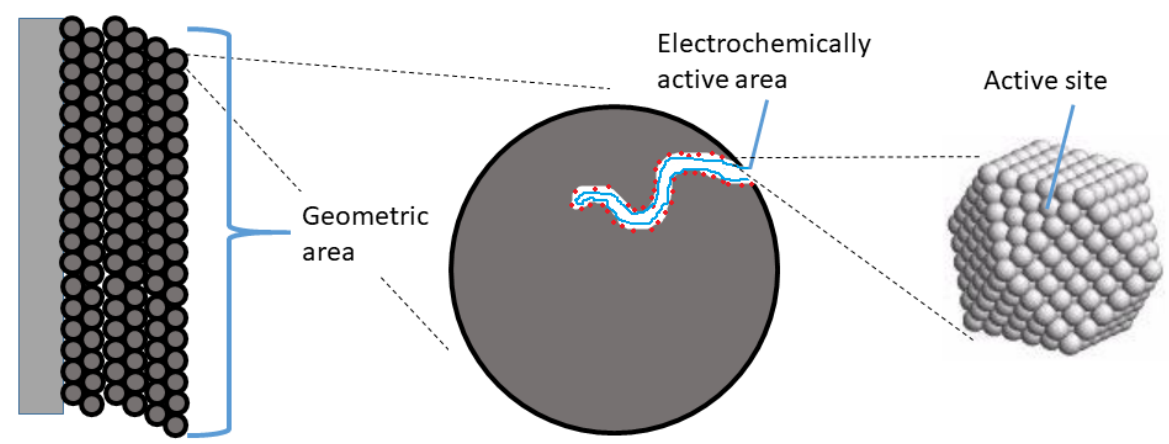

\section{Figure 6.1: Different levels to assess reaction rate}

Many novel electrocatalysts are evaluated based on geometric current density rather than current density per electro-active area or turnover frequency. ${ }^{26-30}$ Therefore, it is difficult to compare performance between studies, as electrode production and operation parameters influence the observed geometric current density. Moreover, superb catalysts incorporated in an unfortunate electrode design, could be wrongfully dismissed as inadequate. ${ }^{26}$ Standardization of initial catalyst assessment procedures, could drastically enhance the interpretability of data from various sources. Standardization could be achieved through initial assessment on a smooth planar electrode, without a presence of catalyst ink additives. This does not imply that promising catalysts should not be evaluated at high current densities, since it is also necessary to evaluate catalysts at commercially relevant conditions. ${ }^{31}$ However, when studying a novel electrocatalysts, characteristics of the electrode structure should be known and vice-versa when studying a novel electrode structure, catalyst 
properties should be known. It is up to researchers, reviewers and editors alike to encourage selection of appropriate performance indicators and variables for the scope of the research.

Given the developments in solar and wind electricity generation and sustainability goals by the European Union and other governments, at least partial electrification of the industry will occur in the future. Currently, the vast majority of energy is primarily liberated as heat of combustion (from fossil resources) ${ }^{32}$ and an overall net conversion of heat to electricity occurs (power plants). ${ }^{33}$ Conversion of heat to electricity is accompanied by significant losses, as a typical power plant has an optimistic efficiency of $\sim 60 \% .{ }^{34}$ With the current fossil based energy mix, electrification of the industry by simple substitution of electricity for heat (e.g. electrically heating a boiler) without additional benefits is wasteful, due to the initial heat to electricity conversion losses in generating the electricity. Since industry is at an initial stage of electrification, there is an option to choose which aspects to electrify first. Industrial processes wherein electrification has additional benefits should be preferred, for example increased efficiency (e.g. electric motor versus combustion engine ${ }^{35}$ ), increased productivity and/or selectivity (e.g. Roto dynamic reactor versus traditional steam cracking ${ }^{36}$ ) or improved work environment (e.g. induction heating versus gas fired heating ${ }^{37}$ ). Here lie chances for electrochemistry, which offers potential in the form of down-scalability, low temperature conversions, and clean \& quiet processes. The future will tell whether electrochemistry is going to be the driving technology for electrification of the chemical industry. Large-scale electrolysis of water for hydrogen production may pave the way for other electrochemical technologies. The coming decades, electrochemistry will be a highly relevant field wherein academic engineers should take responsibility to direct efforts towards implementation, identify potential bottlenecks and manage expectations. 


\section{References}

1. Engel, D. C., Versteeg, G. F. \& Van Swaaij, W. P. M. Reaction kinetics of hydrogen and aqueous sodium and potassium bicarbonate catalysed by palladium on activated carbon. Chemical Engineering Research and Design 73, 701-706 (1995).

2. Min, X. \& Kanan, M. W. Pd-Catalyzed Electrohydrogenation of Carbon Dioxide to Formate: High Mass activity at Low Overpotential and Identification of the Deactivation Pathway. J. Am. Chem. Soc. 137, 4701-4708 (2015).

3. Engel, D. C. Palladium Catalysed Hydrogenation of aqueous bicarbonate salts in formic acid production. (1994).

4. Jiang, B., Zhang, X. G., Jiang, K., Wu, D. Y. \& Cai, W. Bin. Boosting Formate Production in Electrocatalytic CO2 Reduction over Wide Potential Window on Pd Surfaces. J. Am. Chem. Soc. 140, 2880-2889 (2018).

5. Zhou, F., Li, H., Fournier, M. \& MacFarlane, D. R. Electrocatalytic CO2Reduction to Formate at Low Overpotentials on Electrodeposited Pd Films: Stabilized Performance by Suppression of CO Formation. ChemSusChem 10, 1509-1516 (2017).

6. Lee, C. W., Cho, N. H., Nam, K. T., Hwang, Y. J. \& Min, B. K. Cyclic two-step electrolysis for stable electrochemical conversion of carbon dioxide to formate. Nat. Commun. 10, 1-8 (2019).

7. Blommaert, M. A., Verdonk, J. A. H., Blommaert, H. C. B., Smith, W. A. \& Vermaas, D. A. Reduced Ion Crossover in Bipolar Membrane Electrolysis via Increased Current Density, Molecular Size, and Valence. ACS Appl. Energy Mater. 3, 5804-5812 (2020).

8. Han, L. et al. A low temperature aqueous formate fuel cell using cobalt hexacyanoferrate as a non-noble metal oxidation catalyst. Sustain. Energy Fuels 4, 6227-6233 (2020).

9. Zhang, T. et al. Cyclic voltammetry electrodeposition of well-dispersed Pd nanoparticles on carbon paper as a flow-through anode for microfluidic direct formate fuel cells. Nanoscale 12, 20270-20278 (2020).

10. Hren, M., Božič, M., Fakin, D., Kleinschek, K. S. \& Gorgieva, S. Alkaline membrane fuel cells: anion exchange membranes and fuels. Sustain. Energy Fuels (2021). doi:10.1039/d0se01373k

11. Su, X. Y., Pan, Z. F. \& An, L. Three-dimensional porous electrodes for direct formate fuel cells. Sci. China Technol. Sci. (2020). doi:10.1007/s11431-020-1563-5

12. Hwang, H., Hong, S., Kim, J. W. \& Lee, J. Optimized electrode structure for performance and mechanical stability in a direct formate fuel cell using cation ionomer. Sustain. Energy Fuels 4, 1899-1907 (2020).

13. Su, X., Pan, Z. \& An, L. Performance characteristics of a passive direct formate fuel cell. Int. J. Energy Res. 43, 7433-7443 (2019).

14. Luo, S. et al. Flexible direct formate paper fuel cells with high performance and great durability. J. Power Sources 490, (2021).

15. Xiang, H. et al. Production of formate by $\mathrm{CO} 2$ electrochemical reduction and its application in energy storage. Sustain. Energy Fuels 4, 277-284 (2019).

16. Bienen, F. et al. Utilizing Formate as an Energy Carrier by Coupling $\mathrm{CO} 2$ Electrolysis with Fuel Cell Devices. Chemie-Ingenieur-Technik 91, 872-882 (2019).

17. Tran, K., Nguyen, T. Q., Bartrom, A. M., Sadiki, A. \& Haan, J. L. A fuel-flexible alkaline direct liquid fuel cell. Fuel Cells 14, 834-841 (2014).

18. Chen, Z., Wei, W. \& Ni, B. J. Cost-effective catalysts for renewable hydrogen production via electrochemical water splitting: Recent advances. Curr. Opin. Green Sustain. Chem. 27, 100398 (2021).

19. Ong, B. C., Kamarudin, S. K. \& Basri, S. Direct liquid fuel cells: A review. Int. J. Hydrogen Energy 42, 10142-10157 (2017).

20. Kwabi, D. G., Ji, Y. \& Aziz, M. J. Electrolyte Lifetime in Aqueous Organic Redox Flow Batteries: A Critical Review. Chem. Rev. 120, 6467-6489 (2020). 
21. Kim, D. K., Yoon, S. J. \& Kim, S. Transport phenomena associated with capacity loss of allvanadium redox flow battery. Int. J. Heat Mass Transf. 148, 119040 (2020).

22. Pletcher, D. \& Walsh, F. C. Industrial electrochemistry. (Springer Science \& Business Media, 2012).

23. International Enery Agency, I. E. . . \& Nuclear Energy Agency, N. E. A. Projected Costs of Generating Electricity. (2020).

24. Wei, M., McMillan, C. A. \& de la Rue du Can, S. Electrification of Industry: Potential, Challenges, and Outlook. Curr. Sustain. Energy Reports 6, 140-148 (2019).

25. Philibert, C. Direct and indirect electrification of industry and beyond. Oxford Rev. Econ. Policy 35, 197-217 (2019).

26. Zheng, W., Liu, M. \& Lee, L. Y. S. Best Practices in Using Foam-Type Electrodes for Electrocatalytic Performance Benchmark. ACS Energy Lett. 5, 3260-3264 (2020).

27. Pan, F., Zhao, H., Deng, W., Feng, X. \& Li, Y. A novel N,Fe-Decorated carbon nanotube/carbon nanosheet architecture for efficient $\mathrm{CO} 2$ reduction. Electrochim. Acta 273, 154-161 (2018).

28. Huang, P. et al. Single Mo atom realized enhanced CO2 electro-reduction into formate on Ndoped graphene. Nano Energy 61, 428-434 (2019).

29. Sun, L., Reddu, V., Fisher, A. C. \& Wang, X. Electrocatalytic reduction of carbon dioxide: Opportunities with heterogeneous molecular catalysts. Energy Environ. Sci. 13, 374-403 (2020).

30. He, J., Johnson, N. J. J., Huang, A. \& Berlinguette, C. P. Electrocatalytic Alloys for CO2Reduction. ChemSusChem 11, 48-57 (2018).

31. Burdyny, T. \& Smith, W. A. CO2 reduction on gas-diffusion electrodes and why catalytic performance must be assessed at commercially-relevant conditions. Energy Environ. Sci. 12, 1442-1453 (2019).

32. British Petroleum, B. Energy Outlook 2020 edition. (2020).

33. Ritchie, H. \& Roser, M. Energy. Our World in Data (2020).

34. European Commission, J. R. C. Analysis of energy saving potentials in energy generation : Final results. 18 (2012). doi:10.2790/58574

35. Electric, W. \& Transportation, G. The On-line Electric Vehicle. The On-line Electric Vehicle (2017). doi:10.1007/978-3-319-51183-2

36. Coolbrook Roto Dynamic Reactor. Available at: https://coolbrook.com/. (Accessed: 24th February 2021)

37. Lucia, O., Maussion, P., Dede, E. J. \& Burdio, J. M. Induction heating technology and its applications: Past developments, current technology, and future challenges. IEEE Trans. Ind. Electron. 61, 2509-2520 (2014). 



\section{Chapter 7}

\section{Acknowledgement}

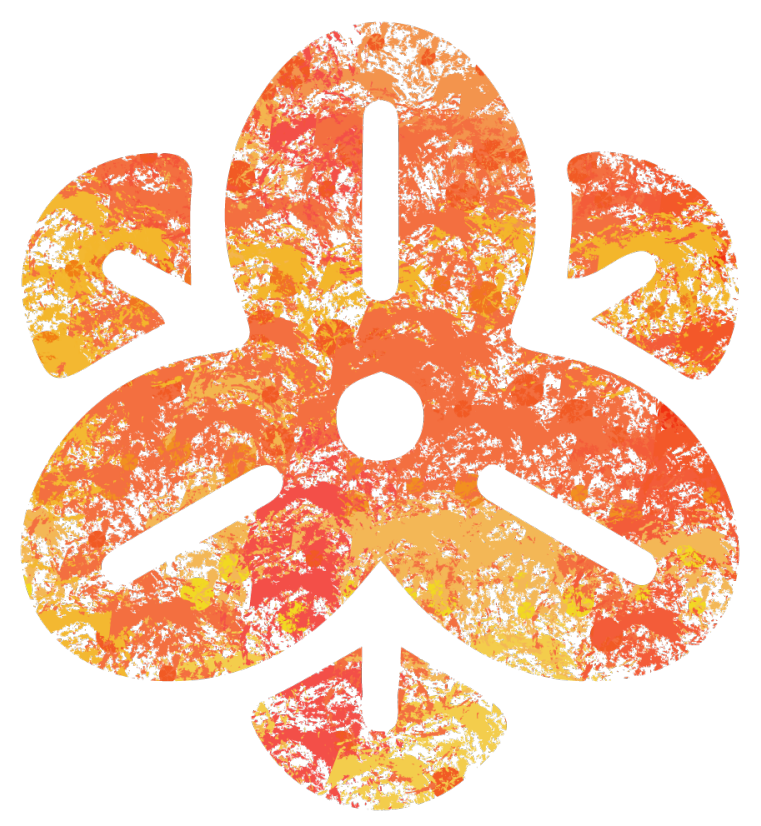

'The seeds of great discoveries are constantly floating around us, but they only take roots in minds well prepared to recieve them'

- Joseph Henry - 


\section{Dankwoord}

Zonder de hulp en het gezelschap van vele collega's, vrienden en familie had ik me nooit zo vermaakt tijdens dit promotieonderzoek en was het resultaat bij lange na niet wat er nu ligt. Dankzij jullie zie ik een PhD doen nog steeds als hobbyen. Hierbij een dankwoord voor de vele jaren plezier aan de Universiteit Twente.

Allereerst wil ik Sacha en Guido bedanken voor de mogelijkheid om dit onderzoek te doen binnen SPT en PCS. Het onderdeel zijn van twee vakgroepen, met complementaire collega's, expertises en faciliteiten heb ik als zeer prettig ervaren. Ik kan het iedereen aanraden.

Sascha, tijdens een van onze eerste ontmoetingen zat jij de krant te lezen terwijl mijn projectgroepje aan jou een presentatie gaf. Een vrij directe, maar duidelijke vorm van feedback. Achteraf denk ik dat dit, iets anders gaan doen wanneer het niet interessant is, het geheim is achter jouw vermogen om heel veel werk te verzetten, bij te blijven bij de actualiteit en nog tijd over te houden voor leuke dingen. Tijdens de Master en ook mijn PhD heb ik namelijk ervaren dat je vrijwel altijd tijd had om iets te bespreken en daarbij met goede ideeën en suggesties kwam. Daarnaast liep je ook vaak het kantoor binnen om te discussiëren/klagen over van alles. Voor mij was het een heel prettige sfeer binnen SPT, zowel creatief als sociaal. Jouw advies, we lossen de problemen pas op als ze zich aandien, heb ik de afgelopen jaren ter harte genomen en bevalt me bijzonder goed.

Guido, jouw optimisme is aanstekelijk, wat altijd voor een goed gevoel zorgt in de groep. Besprekingen waren altijd erg gezellig, positief en productief. Ook op studiereis was jij (samen met Arian) een grote positieve factor in de sfeer binnen de groep. Jij kent altijd en overal wel iemand om mee samen te werken en weet altijd de juiste introducties en verwijzingen maken. Het is niet gek dat PCS veel gedeelde projecten doet en gedeelde apparatuur heeft, waarvoor geheel toevallig altijd plek is op het PCS lab.

Wim, jij bent natuurlijk de aanstichter van de hele onderzoek. Eerst als master opdracht en later als promotieonderzoek. Ik was nooit van plan te gaan $\mathrm{PhD}$ 'en, maar tijdens de masteropdracht begon het toch te kriebelen, mede door de grote hoeveelheid interessante onderzoeksvragen die voorkwam uit jouw idee voor formiaat als opslagmedium. Jij hebt een schat aan ervaring en kunt dat zeer levendig overbrengen. Niet zelden begon jij het eerste half uur van een bespreking met de woorden: "In de jaren tachtig..." Dan volgende een verhaal met vele leuke anekdotes, meestal leerzaam, altijd vermakelijk.

Yvonne, Lidy en Dorothy, zonder jullie loopt alles vast en zouden we allemaal hopeloos verloren zijn. Yvonne, zonder jouw hulp bij het plannen van besprekingen in drukke agenda's en het navigeren van het labyrint dat Prodoc/Hora Finita/TGS/MyHR/AFAS heet, zou ik nu nog bezig zijn met een aanstelling te verkrijgen. Lidy en Dorothy, jullie zijn ook onmisbaar geweest in het proces Guido, Sascha en Wim tegelijkertijd in één ruimte te krijgen. Daarnaast was het altijd gezellig binnenlopen voor een praatje en dragen jullie sterk bij aan de goede sfeer in de groep. Super bedankt daarvoor. 
Het is onmogelijk om goed toegepast onderzoek te bedrijven zonder bekwame technici. Robert, jij hebt voor mij een prachtige opstelling gebouwd, die alle metingen mogelijk heeft gemaakt. Ongelooflijk hoe jij in je eentje PCS op technisch vlak draaiende weet te houden. Rob, jij hebt voor mij, in een aantal iteraties, een prachtige reactor gemaakt, welke ik veelvuldig gebruikt heb. Daarnaast vond ik het superleuk om bij jou te leren draaien en frezen. Het eindwerkstuk pronkt op mijn bureau. Erna, wij hebben veel samengewerkt met betrekking tot de HPLC. Als er problemen waren, dan stond je altijd snel klaar om die op te lossen. Het mag niet onderschat worden hoe belangrijk accurate, robuuste analyseapparatuur is, wat jij waarborg. Daarnaast wil ik natuurlijk ook Benno, Johan, Karst en Ronald bedanken voor de hulp in het HDL en grapjes die jullie maken.

Ook de rest van de staf wil ik bedanken voor jullie ideeën, bijdragen en gezelligheid. Louis, jij bent altijd geïnteresseerd en medelevend met iedereen. Zonder jou zou het onderwijs niet zijn wat het nu is. Wim, jij bent een bevangen docent en gedreven onderzoeker. Als ik een schoolvoorbeeld professor moest aanwijzen, dan ben jij het. Boelo, als jij bij de vrijdagmiddagborrel was, had ik zaterdag hoofdpijn. Henk, gesprekken met jou hielpen mij enorm in het grote plaatje duidelijk krijgen. Pilar, jij bent een aanwinst voor SPT, zowel op wetenschappelijk als sociaal vlak. Bastian, bedankt voor het meedenken als ik weer eens met een elektrochemische vraag zat. Jean-Paul, jouw lezingen en kritische vragen houden altijd het grotere plaatje in gedachte, en zodoende de technoloog scherp. Annemarie, lasers zijn natuurlijk sowieso gaaf, maar jij weet zo ook nog eens nuttig te gebruiken. Edwin en Meik ik ben blij dat met jullie de SPT-groep verder uitgebreid wordt. Langzaam nemen we de meander over.

Ik heb geluk gehad met de vele leuke collega's op de UT. Allereerst mijn paranimfen. Thomas, we kennen elkaar al vanaf de middelbare school en dat is eigenlijk altijd ellende geweest. Het gaat bijna nooit ergens over, maar het is altijd lachen. Ik heb er alle vertrouwen in dat we elkaar nog (te) vaak blijven zien. Thimo, ik waardeer onze serieuzere gesprekken over allerlei maatschappelijke en technische thema's altijd zeer. Jouw interesse in iedereens onderzoek, en dan met name jouw vermogen om te onthouden wat mensen je vertellen, vind ik bewonderenswaardig. Ik kan er nog steeds niet helemaal bij dat jij vader gaat worden, maar misschien is een tweede kind in huis wel zo leuk voor Martine. Juraj, jij hoort ook in dit rijtje thuis. Blijkbaar kan het communisme toch iets goeds voortbrengen en ik ben blij dat je daarvan jerrycans vol naar Nederland brengt. De woorden 'I went full Juraj' uit jouw eigen mond zullen me altijd bij blijven. Jij brengt overal gezelligheid mee en naast goede verhalen vertellen weet je er ook heel veel te maken. Tomas, Thimo en Juraj, ik hoop met jullie nog vele dagen om 10 uur de frituur aan te slingeren, hoofdpijn te hebben en spijt te hebben van onze levenskeuzes.

Dan de rest van mijn collega's. Vincent, jouw gevoel voor humor en kennis van onzinnige feitjes maakten elke lunch gezellig. Qua grappen weet je altijd precies waar het randje ligt, maar je hebt dan ook al heel veel jaren kunnen zoeken. Thomas, mijn overbuurman op kantoor. Zeker de laatste maanden hebben we veel gepraat en dat was wel zo vermakelijk. Surika, bedankt dat je nooit hebt leren kaarten. Dat maakt tegen jou spelen altijd leuk. Het 
was super leuk om bij jou op kantoor te zitten, maar je moet iedereen niet zo lopen plagen... Lisette, jouw baksels zijn geweldig. Ik snap waarom je zulke einden loopt. Rick, als ik iemand ken met een goed ontwikkeld moreel kompas ben jij het. Ik denk dat jij een aanwinst bent in elke groep. Yordi, jij had de nobele taak om de biervoorraad op pijl te houden, welke je met verve vervulde. Mijn vrijdagen zijn je dankbaar, mijn zaterdagen wat minder. Tim, als jij het niet kan modelleren bestaat het waarschijnlijk niet. Jasper, blijf alsjeblieft memes mailen naar studenten. Af en toe moet ik er nog steeds om lachen. Piotr, met jou in het lab staan is altijd leuk. Zeker als je het onmogelijke probeert te doen. Vera, bedankt dat je me wegwijs hebt gemaakt in de wereld van elektrochemie. Anne, door met jou te kletsen kwamen er altijd goede ideeën naar boven. Margot, super dat jij na je master opdracht bij PCS bent blijven hangen. Jij bent gedreven en sociaal, een goede combinatie. An, de verhalen die jij over Vietnam verteld kunnen me elke keer weer verbazen. Devin, jij hebt mijn culinaire wereld enorm verrijkt. Zeker fusion wok had ik jaren eerder moeten leren kennen. Varsha, Chiel, Eshan, Vahideh, Mahsa, Lionel, Dion, Ronald, Mozhgan, Natalia en Kai, jullie ook heel bedankt voor de sfeer in kantoor, discussies en hulp met experimenten.

Natuurlijk wil ik ook iedereen die een bachelor, master of stageopdracht heeft gedaan bedanken. Jullie werk is essentieel geweest in het vergaren van inzicht en kennis. Jochem, jouw modelleer werk is de basis geweest voor begrip van het massatransport in de electrolyzer. Jalmar, de brandstofcel opstelling die jij gebouwd hebt heeft nog vele uren gedraaid en was de basis voor het MEA onderzoek. Fabian, jouw werk aan de MEAs heeft tot vele nieuwe inzichten geleid en de realisatie dat de brandstofcel te veel onderzoek vereiste om nog binnen dit proefschrift te passen. Margot, bijna al mijn kennis van membranen komt uit jouw onderzoek. Zelfs binnen mijn huidige baan pak ik het er nog weleens bij. Matthijs, jouw verkennende modelleerwerk was top. Rewie, jij hebt de laatste metingen met de opstelling gedaan, welke op de valreep nog temperatuur data opleverden. Een mooi beginpunt voor vervolgonderzoek.

Als laatste bedankt ik ook mijn familie. Papa en mama, bedankt dat jullie mij gestimuleerd hebben om nieuwsgierig te zijn en zelf te kiezen wat ik wil doen. Jullie zijn heel ondersteunend, wat mij altijd een ontspannen gevoel geeft. Jullie hebben mij geleerd om in het oog te houden wat écht belangrijk voor je is in het leven en dat er altijd weer een nieuwe dag komt. Alyssa, jou bedank ik natuurlijk het meest van iedereen. Zonder jouw baksels hadden mijn collega's me nooit gemogen. Je hebt geduldig naar mijn frustraties geluisterd als iets niet werkte zoals ik wilde en heel lief gedaan alsof je iets van mijn geraaskal volgde. Ik ben super blij dat je met me mee wilde naar België en ik hoop dat wij nog heel lang samen gaan zijn!

Ongetwijfeld ben ik mensen vergeten in dit dankwoord (ik ken mezelf). Daarom, als ik je niet genoemd heb, hieronder de ruimte om jezelf toe te voegen. , heel erg bedankt voor zonder jou was het nooit gelukt om dit promotieonderzoek tot een goed einde te brengen. 




\section{List of journal publications}

Blom, M.J.W., van Swaaij, W.P.M., Mul, G. \& Kersten, S.R.A. Overall mass balance evaluation of electrochemical reactors: The case of $\mathrm{CO}_{2}$ reduction. Electrochimica Acta 333 (2020) 135460.

Blom, M.J.W., Smulders, V., van Swaaij, W.P.M., Kersten, S.R.A., \& Mul, G. Pulsed electrochemical synthesis of formate using $\mathrm{Pb}$ electrodes. Applied Catalysis B: Environmental 268, (2020) 118420.

Blom, M.J.W., van Swaaij, W.P.M., Mul, G. \& Kersten, S.R.A. Increased hydrogen partial pressure suppresses and reverses hydrogen evolution during Pd catalyzed electrolysis of $\mathrm{CO}_{2}$. Sustainable Energy and Fuels 4 (2020) 4459-4463.

Blom, M.J.W., van Swaaij, W.P.M., Mul, G. \& Kersten, S.R.A Mechanism and Micro Kinetic Model for Electroreduction of $\mathrm{CO}_{2}$ on $\mathrm{Pd} / \mathrm{C}$ : The Role of Different Palladium Hydride Phases ACS Catalysis 11, 12 (2021), 6883-6891 



\begin{abstract}
About the author
Martijn Blom was born in Sliedrecht on October 17 $7^{\text {th }}$ 1992. He lived in Bovenkarspel from the age of four and attended highschool at the RSG in Enkhuizen. There he completed his VWO with a nature and technology profile. Martijn obtained his bachelor degree in chemical engineering at the University of Twente and performed his bachelor assignment on hydrothermal gasification of biomass. Martijn also obtained has master degree in chemical and process engineering from the University of Twente. His master assignment concerned electrochemical production of formate, which formed the beginning of this $\mathrm{PhD}$ work. Currently, Martijn is employed by imec in Leuven, where he continues working with electrochemistry. In his free time, he likes to run, cycle or do woodworking.
\end{abstract}





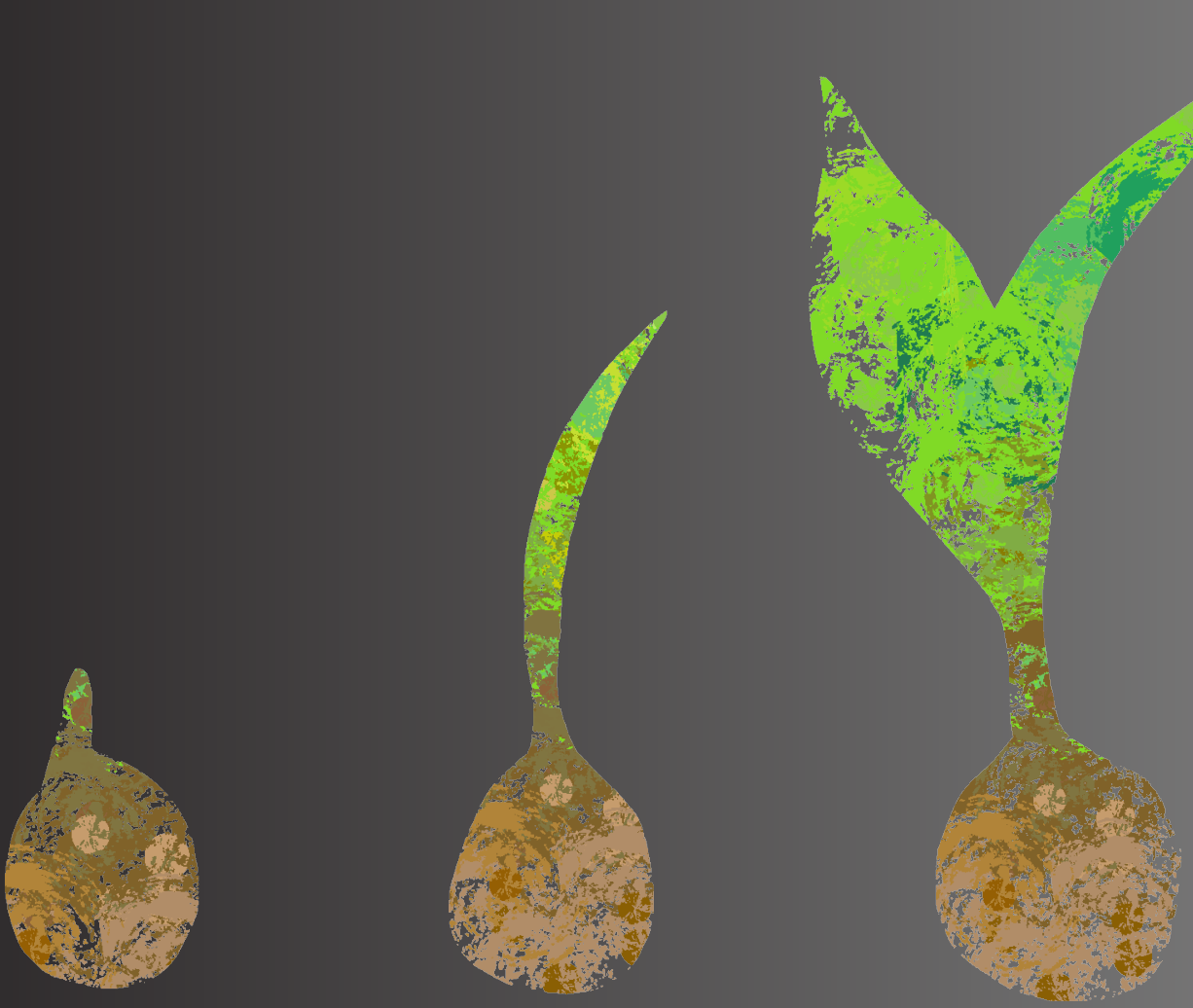

ISBN: 978-90-365-5262-2 